Prepared in cooperation with the Missouri Department of Natural Resources

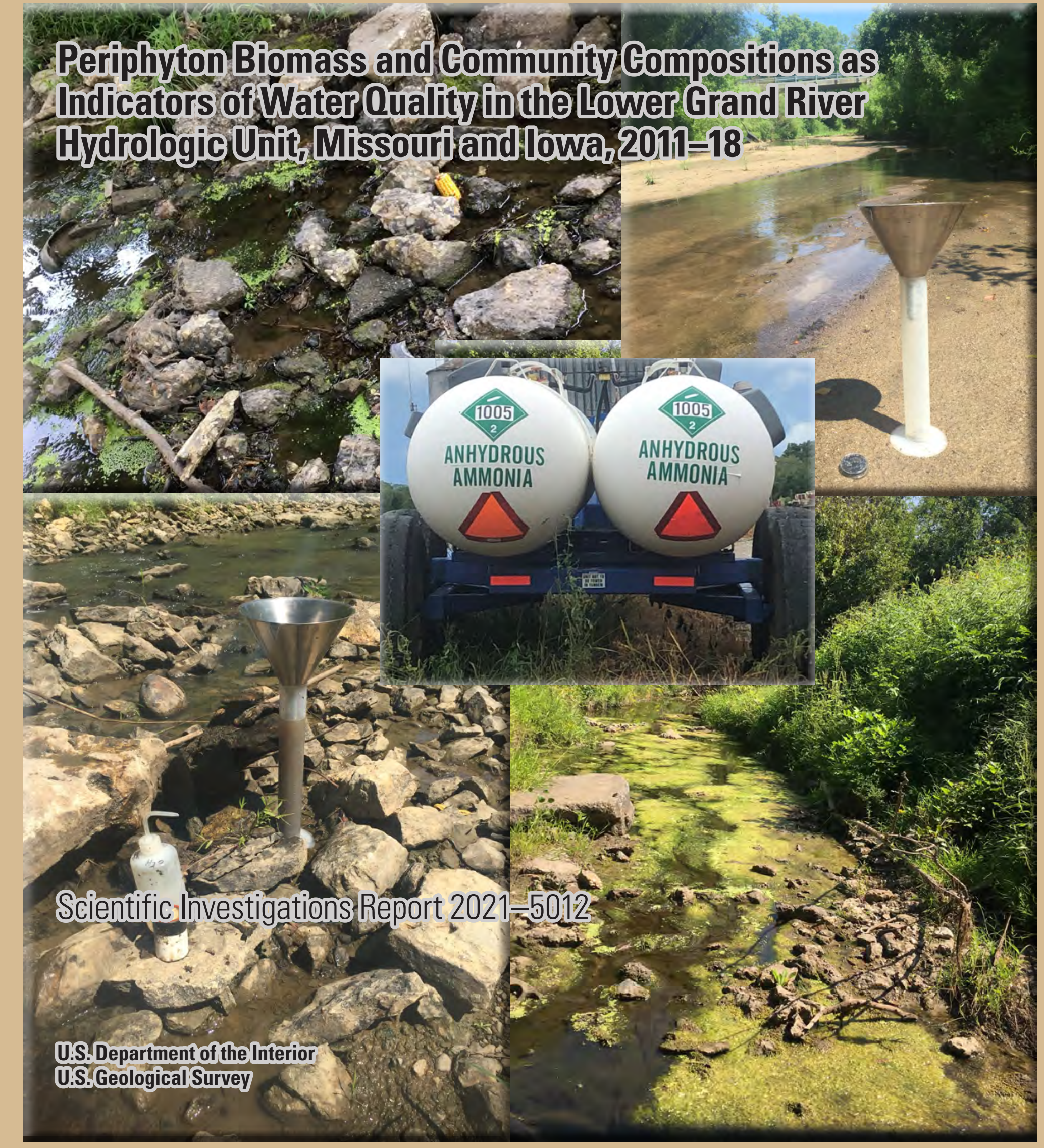




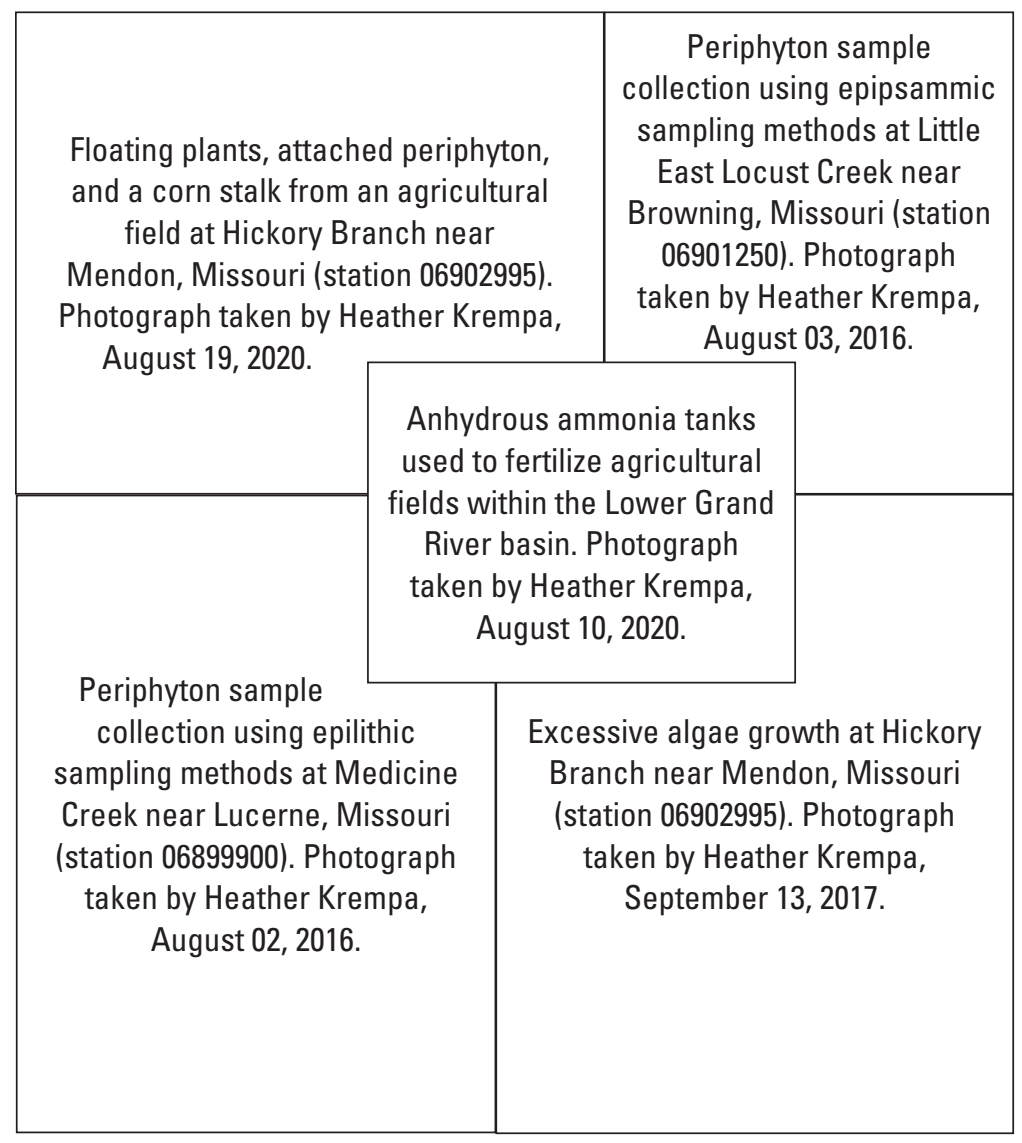




\section{Periphyton Biomass and Community Compositions as Indicators of Water Quality in the Lower Grand River Hydrologic Unit, Missouri and lowa, 2011-18}

By Heather M. Krempa

Prepared in cooperation with the Missouri Department of Natural Resources

Scientific Investigations Report 2021-5012 


\section{U.S. Geological Survey, Reston, Virginia: 2021}

For more information on the USGS - the Federal source for science about the Earth, its natural and living resources, natural hazards, and the environment—visit https://www.usgs.gov or call 1-888-ASK-USGS.

For an overview of USGS information products, including maps, imagery, and publications, visit https://store.usgs.gov/.

Any use of trade, firm, or product names is for descriptive purposes only and does not imply endorsement by the U.S. Government.

Although this information product, for the most part, is in the public domain, it also may contain copyrighted materials as noted in the text. Permission to reproduce copyrighted items must be secured from the copyright owner.

Suggested citation:

Krempa, H.M., 2021, Periphyton biomass and community compositions as indicators of water quality in the Lower Grand River hydrologic unit, Missouri and lowa, 2011-18: U.S. Geological Survey Scientific Investigations Report 2021-5012, 51 p., https://doi.org/10.3133/sir20215012.

Associated data for this publication:

Krempa, H.M., 2020, Periphyton community data within the Lower Grand River hydrologic unit code 10280103, Missouri and lowa, 2011-2018: U.S. Geological Survey data release, https://doi.org/10.5066/P9BYF1EN.

U.S. Geological Survey, 2020, USGS water data for the Nation: U.S. Geological Survey National Water Information System database, https://doi.org/10.5066/F7P55KJN.

ISSN 2328-0328 (online) 


\section{Contents}

Abstract

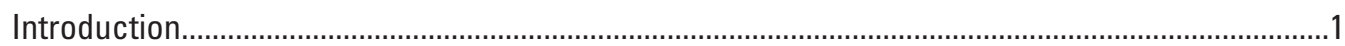

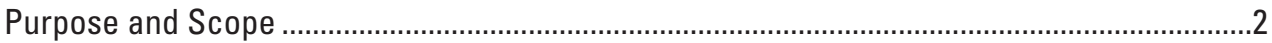

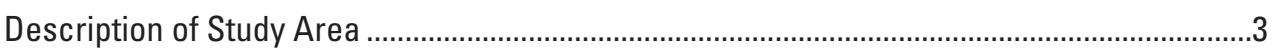

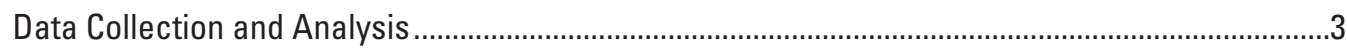

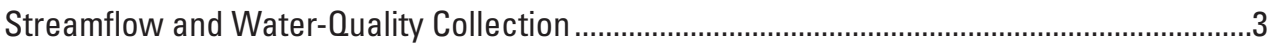

Periphyton Sample Collection .................................................................................................

Quality Assurance and Quality Control ...................................................................................

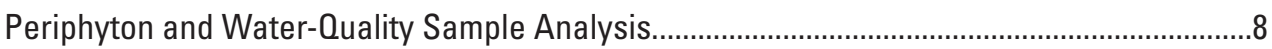

Water-Quality Sample Concentrations...........................................................................

Periphyton Biomass and Water-Quality Relations ............................................................12

Periphyton Community Composition ................................................................................12

Water-Quality Effects on Periphyton Community Similarities ............................................12

Periphyton Community Attributes and Taxa Metrics .....................................................12

Water-Quality Sample Concentrations.....................................................................................13

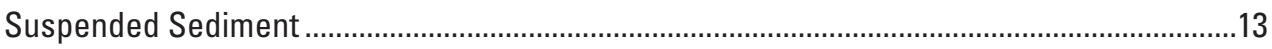

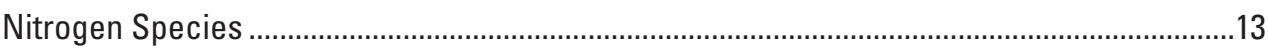

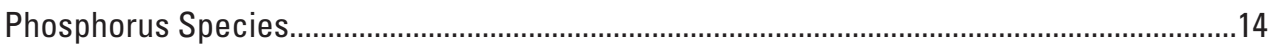

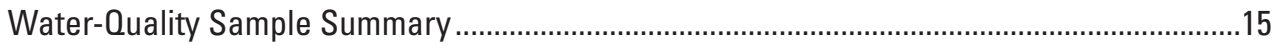

Periphyton Biomass and Community Structure ......................................................................15

Periphyton Biomass and Water-Quality Relations ..............................................................16

Periphyton Community Composition...................................................................................21

Water-Quality Effects on Periphyton Community Similarities ..................................................27

Periphyton Community Attributes and Taxa Metrics ...............................................................2

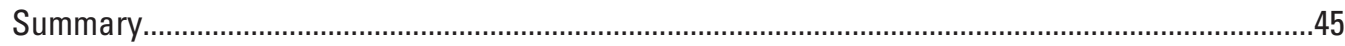

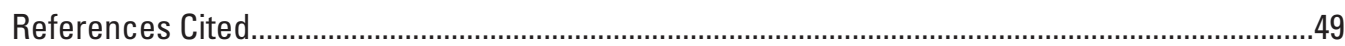

\section{Figures}

1. Map showing locations of U.S. Geological Survey water-quality collection sites in the Lower Grand River hydrologic unit, Missouri and lowa.........................................

2. Photographs showing periphyton sample collection at water-quality collection sites in the Lower Grand River hydrologic unit, Missouri and lowa .................................6

3. Nonparametric multidimensional scaling plot of periphyton taxa biovolume with year and identifying laboratory indic ated......................................................................

4. Graphs showing ash-free dry mass and chlorophyll concentrations at water-quality collection sites in the Lower Grand River hydrologic unit, Missouri and lowa, 2010 through 2018. 


\section{Tables}

1. Description of U.S. Geological Survey water-quality collection sites in the Lower Grand River hydrologic unit, Missouri and lowa, including land use within each site's drainage area.

2. Statistical information describing periphyton sample concentrations and physical parameters at sites in the Lower Grand River hydrologic unit, Missouri and lowa, 2010 through 2018.

3. Statistical information describing water-quality sample concentrations at sites in the Lower Grand River hydrologic unit, Missouri and lowa, 2010 through 2018

4. Probability values and coefficients of determination determined from ordinary least squares regression models between ash-free dry mass and chlorophyll concentrations with water-quality constituents at sites in the Lower Grand River hydrologic unit, Missouri and lowa, 2010 through 2018.

5. Periphyton taxa abundance summary information from samples collected at sites in the Lower Grand River hydrologic unit, Missouri and lowa, 2011 through 2018

6. Dominant periphyton taxa summary information from samples collected at sites in the Lower Grand River hydrologic unit, Missouri and lowa, 2011 through 2018.

7. Periphyton attribute statistical summary information of metric classes for periphyton samples collected in the Lower Grand River hydrologic unit, Missouri and lowa, 2011 through 2018.

8. Relative abundance of national attributes describing nutrient concentrations by metric class for periphyton samples collected in the Lower Grand River hydrologic unit, Missouri and lowa, 2011 through 2018

9. Relative abundance of national and regional attributes describing total nitrogen or total phosphorus concentrations by metric class for periphyton samples collected in the Lower Grand River hydrologic unit, Missouri and lowa, 2011 through 2018 .

10. Relative abundance of national attributes describing organic enrichment by metric class for periphyton samples collected in the Lower Grand River hydrologic unit, Missouri and lowa, 2011 through 2018.

11. Relative abundance of national attributes describing nuisance algae, $\mathrm{pH}$, and salinity by metric class for periphyton samples collected in the Lower Grand River hydrologic unit, Missouri and lowa, 2011 through 2018.

12. Relative abundance of national attributes describing conductance and chloride concentrations by metric class for periphyton samples collected in the Lower Grand River hydrologic unit, Missouri and lowa, 2011 through 2018.

13. Relative abundance of national attributes describing microhabitats, suspended sediments, and calcium concentrations by metric class for periphyton samples collected in the Lower Grand River hydrologic unit, Missouri and lowa, 2011 through 2018 


\section{Conversion Factors}

International System of Units to U.S. customary units

\begin{tabular}{lll}
\hline \multicolumn{1}{c}{ Multiply } & By & To obtain \\
\hline & Area & \\
\hline square kilometer $\left(\mathrm{km}^{2}\right)$ & 0.3861 & square mile $\left(\mathrm{mi}^{2}\right)$ \\
\hline & Volume & \\
\hline milliliter $(\mathrm{mL})$ & 0.033814 & ounce, fluid (fl. oz) \\
\hline
\end{tabular}

Temperature in degrees Celsius $\left({ }^{\circ} \mathrm{C}\right)$ may be converted to degrees Fahrenheit $\left({ }^{\circ} \mathrm{F}\right)$ as follows:

$$
{ }^{\circ} \mathrm{F}=\left(1.8 \times{ }^{\circ} \mathrm{C}\right)+32 \text {. }
$$

\section{Datum}

Vertical coordinate information is referenced to the North American Vertical Datum of 1988 (NAVD 88).

Horizontal coordinate information is referenced to North American Datum of 1983 (NAD 83).

\section{Supplemental Information}

Specific conductance is given in microsiemens per centimeter at 25 degrees Celsius $(\mu \mathrm{S} / \mathrm{cm}$ at $\left.25^{\circ} \mathrm{C}\right)$.

Concentrations of chemical constituents in water are given in either milligrams per liter (mg/L) or micrograms per liter $(\mu \mathrm{g} / \mathrm{L})$.

Ash-free dry mass concentrations are given in grams per square meter $\left(\mathrm{g} / \mathrm{m}^{2}\right)$.

Chlorophyll concentrations are given in milligrams per square meter $\left(\mathrm{mg} / \mathrm{m}^{2}\right)$.

Biovolume is given in cubic centimeters per square meter $\left(\mathrm{cm}^{3} / \mathrm{m}^{2}\right)$.

Discharge is given in cubic feet per second ( $\mathrm{ft} 3 / \mathrm{s})$. 


\section{Abbreviations}

$\begin{array}{ll}\text { AFDM } & \text { ash-free dry mass } \\ \text { BOD } & \text { biochemical oxygen demand } \\ \text { EPA } & \text { U.S. Environmental Protection Agency } \\ \text { MCL } & \text { maximum contamination limit } \\ \text { MDS } & \text { multidimensional scaling } \\ \text { MRBI } & \text { Mississippi River Basin Healthy Watersheds Initiative } \\ \text { NRCS } & \text { Natural Resources Conservation Service } \\ \text { NWIS } & \text { National Water Information System } \\ \text { OBN } & \text { organically bound nitrogen } \\ p \text {-value } & \text { statistical probability value } \\ R^{2} & \text { coefficient of determination } \\ \text { USGS } & \text { U.S. Geological Survey }\end{array}$




\title{
Periphyton Biomass and Community Compositions as Indicators of Water Quality in the Lower Grand River Hydrologic Unit, Missouri and lowa, 2011-18
}

\author{
By Heather M. Krempa
}

\section{Abstract}

Biological communities, including periphyton, are continuously affected by chemical, physical, and other biological factors, and the health of these communities can reflect the overall health of the aquatic system. A diverse community is more robust, and communities with lower richness and evenness often indicate a degraded community dominated by few taxa tolerant to the degraded conditions, which makes the community more susceptible to ecological changes. Water-quality nutrient samples were collected at sites in the Lower Grand River during 2010 through 2018 and periphyton sample collections began in 2011 to describe the periphyton community and overall ecological health. Nutrient sample concentrations were generally elevated at these sites, which can lead to eutrophication, excessive plant and algae growth, drinking-water taste and odor problems, low dissolved-oxygen concentrations, and harmful algal blooms. Concentrations of total nitrogen were greater than acceptable as described by the U.S. Environmental Protection Agency, and total phosphorus concentrations were greater than reference concentrations. Periphyton communities were dominated by taxa that are tolerant to or indicative of elevated nutrient concentrations; and nuisance algae, or harmful algal bloom producers, were identified at all sites, except one. The presence of these producers indicates that harmful algal blooms may have high potential during optimal conditions at these sites. Chlorophyll concentrations that exceed 100 milligrams per square meter are considered nuisance and were determined in 11 percent of the samples and at every site during September 2012. Samples were collected during low-flow conditions when nutrient concentrations are generally lower than during high-flow and runoff conditions. Elevated nutrient concentrations during low-flow conditions indicate nutrient concentrations are likely elevated throughout most of the year. Agriculture is the primary land use within the Lower Grand River and is likely a primary source of nutrients and sediments. Conservation practices intended to reduce nutrient loss from agriculture fields have increased because of the Mississippi River Basin Healthy Watersheds Initiative and will potentially increase the ecological, chemical, and physical health of these waterways.

\section{Introduction}

Water quality can describe the chemical, physical, and biological state of water, which can change frequently, rapidly, and in response to natural factors and human activities.

Ideal water-quality conditions vary regionally, vary among waterbodies, and can be different depending on the water use considered. This variability makes it difficult to determine the overall health of a stream, which often is compared to "least impacted" streams, similar waterbodies, or in relation to specific biological communities or human uses. Biological communities are continuously affected by numerous chemical, physical, and other biological factors, and the health of these communities can reflect the overall health of the aquatic system over time and space.

Nutrients, specifically nitrogen and phosphorus, in aquatic systems are essential for biological growth; however, excessive nutrient concentrations impair the health of the aquatic community. Nitrogen or phosphorus is usually the factor limiting plant and algae growth, and high concentrations often result in excessive growth of plants and periphyton, a process known as eutrophication, which can lead to dissolved-oxygen concentrations low enough to kill fish and other aquatic life. Excessive nutrients can also cause harmful algal blooms that are toxic to wildlife, pets, and humans and cause taste and odor problems in drinking-water sources. Excessive growth of plants, periphyton, and harmful algal blooms are also economically damaging because they reduce recreational opportunities such as boating, swimming, and fishing and increase costs for irrigation and drinking-water treatment. Additionally, excessive nitrate and nitrite in drinking water can cause adverse human health effects including restricting oxygen transport in the bloodstream (Land and others, 1998), causing infant methemoglobinemia, cancer, and adverse reproductive outcomes (National Research Council, 1995; Ward and others, 2018). 
Nutrients are present naturally from plant decay and wildlife waste and are produced by many human activities including wastewater treatment plants, motor vehicle emissions, industrial discharges, urban lawn and golf course fertilizers, agriculture field drainage and runoff, and pet and livestock waste. Nutrients have been listed as one of the top five reported causes of impairment in assessed streams and rivers in the National Water Quality Inventory Report to Congress every year since the initial report in 1992 (U.S. Environmental Protection Agency [EPA], variously dated). The EPA National Rivers and Streams Assessment determined that biological condition is the best descriptor for waterbody health because healthy biological communities are typically found in waters with good chemical and physical conditions as well (EPA, 2017). This study determined that 46 percent of river and stream miles are in poor biological condition, excess nutrients had the greatest impact on the biological condition, and excess nutrients were the most widespread chemical stressor (EPA, 2017). The physical habitat stressor that had the greatest effect on biological condition was sediments, even though poor riparian vegetative cover and high levels of riparian disturbance were more widespread.

Many biological communities are used as indicators of water-quality and ecological health. Periphyton communities consist of algae, bacteria, microbes, and other organisms that are attached to submerged substrates. They are the base of the stream system food web, and they link nonliving factors, including nutrients, to higher trophic levels, such as macroinvertebrates and fish, that consume them. Periphyton communities have short life cycles allowing them to respond rapidly to chemical and physical changes in the environment, and many communities are sedentary making them sensitive to changes in water quality. Additionally, they have been well studied, so their ability to tolerate physical and chemical hardships are described for many taxa. These characteristics make periphyton good indicators of water quality and ecological health.

Periphyton biomass has been related to nutrient availability and is expected to increase with nutrients; however, many factors, other than nutrient availability, affect periphyton growth. Optimum nutrient ratios (ratio of nitrogen to phosphorus) differ among periphyton species complicating responses to nutrient availability (Borchardt, 1996; Petersen and Femmer, 2002). Other factors include light availability, water temperature, grazing pressure, and physical and chemical disturbances. Light is needed for photosynthesis, and riparian vegetation is often reduced in agricultural and urban streams compared to streams in forested watersheds, increasing light availability. Riparian shading also affects water temperature, which affects metabolic rates and periphyton species composition (Petersen and Femmer, 2002). Scouring during streamflow increases and grazing herbivores can reduce overall biomass and alter species composition. Although many factors affect periphyton biomass and species composition, their tolerance, preference, and optimum range for a variety of physical and chemical factors are known and can be used to assess the ecological condition of aquatic systems.

The U.S. Geological Survey (USGS) and the Missouri Department of Natural Resources began a cooperative study in the Lower Grand River hydrologic unit in Missouri and Iowa (hereafter referred to as "Lower Grand River") in 2010 to describe stream nutrient changes in the Lower Grand River using nutrient and periphyton samples. The Lower Grand River was determined to be a priority area for the Mississippi River Basin Healthy Watersheds Initiative (MRBI; Natural Resources Conservation Service [NRCS], variously dated). The MRBI offers financial and technical assistance to agricultural producers in priority watersheds, including the Lower Grand River, to implement voluntary conservation practices on working agricultural lands. Watersheds were determined to be priorities based on large areas of agricultural land use. The intent is to reduce nutrient and sediment export to surface waters while improving infield soil health within the Missouri River Basin, solving local resource issues on individual participant's land and, in doing so, improving water quality locally and within the Mississippi River watershed.

The Mississippi River watershed was identified as a top priority for nutrient reductions by the U.S. Department of Agriculture NRCS because the primary sources of organic matter in the northern Gulf of Mexico are driven by nutrient inputs, especially nitrogen, from the Mississippi River watershed (Rabalais and others, 2002), where the primary land use is agriculture, and nitrogen inputs are dominated by agricultural sources (Howarth, 2008). Nutrient loading degrades local waterbodies and results in the annual midsummer northern Gulf of Mexico hypoxic zone or "dead zone" (Rabalais and others, 2002). This hypoxic zone occurs during summer stratification when the decomposition of organic matter, which is an oxygen-consuming process, outpaces oxygen diffusion, which results in oxygen concentrations below critical thresholds for most living organisms in the lower stratified zone (Rabalais and others, 2002).

\section{Purpose and Scope}

The purpose of this report is to present the results of an assessment of the water-quality and ecological health of streams within the Lower Grand River by characterizing the periphyton community at six sites. Periphyton sample and taxonomic information was published in a publicly available data release (Krempa, 2020). Ash-free dry mass (AFDM) and chlorophyll concentrations were used to assess relations between periphyton biomass and physical and chemical parameters using ordinary least squares regression models. 
Chlorophyll concentrations that exceed 100 milligrams per square meter $\left(\mathrm{mg} / \mathrm{m}^{2}\right)$ have been described as nuisance algal conditions (Horner and others, 1983; Lohman and others, 1992; Rasmussen and others, 2009; Welch and others, 1988), and concentrations for this report were compared to this threshold. Nonparametric multidimensional scaling (MDS) was used to display similarities among samples using periphyton taxa biovolumes. Factors including site, year, month, and tertials of total nitrogen, total phosphorus, suspended sediment, chlorophyll, and AFDM were displayed on the MDS graph to assess effect on sample similarities. The periphyton community and ecological health were assessed using community attributes and taxa metrics to describe the community composition and characteristics.

\section{Description of Study Area}

The Lower Grand River was the focus of this study because it was considered a priority area for the MRBI and received increased funding to support voluntary conservation practices and monitoring beginning in 2010 (NRCS, variously dated). The primary objectives of the study have been to collect water-quality and hydrologic data, to characterize concentrations of nutrients and suspended sediments, and to assess the ecological condition using biological communities at six sites in the Lower Grand River. Previous studies have assessed the water quality using nutrient and sediment concentrations, determined changes in nutrient concentrations among sites and years, and determined relations between nutrient concentrations and conservation practices and agricultural activities (Wilkison and Armstrong, 2015; Krempa and Flickinger, 2017).

The Lower Grand River hydrological unit, a tributary to the Missouri River (fig. 1), is part of the Grand River Basin, which was a priority watershed for the MRBI beginning in 2010. Six water-quality collection sites were established in the Lower Grand River in October or November 2010 (fig. 1; table 1). The drainage areas of these sites' range from 36 to 1,434 square kilometers $\left(\mathrm{km}^{2}\right)$, and agriculture is the primary land use within each site's drainage area (69 to 88 percent). Forest is the secondary land use, and the greatest amount of forest was 21 percent. Less than 5 percent of each site's drainage area is described as urban, wetland, grassland, or open water (Homer and others, 2015).

\section{Data Collection and Analysis}

Physical parameters, water-quality samples, and biological data were collected at each site. Water-level stage (height of water level referenced to a known elevation) was used to determine streamflow from stage-streamflow relations. Streamflow was measured regularly, and physical parameters and water-quality samples were collected with periphyton samples. Additional water-quality samples were collected (about 12 times annually) at these sites to describe nutrient concentration changes and responses to conservation practices (Wilkison and Armstrong, 2015; Krempa and Flickinger, 2017). Water-quality samples collected with periphyton samples were used to describe the conditions during periphyton sampling. Periphyton biomass samples were collected after a 2-week period without substantial streamflow increases to remove bias from scour effects and 1-5 times annually, except in 2015 when there was not a period without 2 weeks of substantial streamflow increases.

\section{Streamflow and Water-Quality Collection}

USGS streamflow-gaging stations were established at water-quality collection sites. Water-level stage data were recorded every 15 minutes using nonsubmersible pressure transducers and uploaded to the USGS National Water Information System (NWIS) database (USGS, 2020). Streamflow measurements routinely were made using standard USGS procedures to develop and maintain stage-streamflow relations for each site (Turnipseed and Sauer, 2010). This relation was used to compute streamflow from stage data, which is stored in the USGS National Water Information System database. Streamflow values recorded at the time closest to periphyton sample collections were used in analyses.

Physical parameters and water-quality samples were collected with periphyton samples. Physical parameters, including dissolved oxygen, $\mathrm{pH}$, specific conductance, turbidity, and water temperature, were measured using a multiparameter field-measurement instrument and appropriate USGS guidelines (USGS, 2008). Water-quality samples were analyzed for suspended-sediment and nutrient concentrations including ammonia plus organic nitrogen, dissolved ammonia, dissolved nitrite, dissolved nitrate plus nitrite, organic nitrogen, total nitrogen, dissolved phosphorus, dissolved orthophosphate, and total phosphorus. Suspended-sediment and nutrient samples were collected and processed using standard equal-width increment collection methods representative of the entire water column (USGS, variously dated). Suspended-sediment samples were analyzed at the Missouri Sediment Laboratory (Rolla, Missouri), and nutrient samples were analyzed at the USGS National Water Quality Laboratory according to published USGS laboratory methods in use during the time of sample collection and analysis (Fishman, 1993; Fishman and others, 1994; Patton and Kryskalla, 2003, 2011; Patton and Truitt, 1992, 2000; EPA, 1993). 


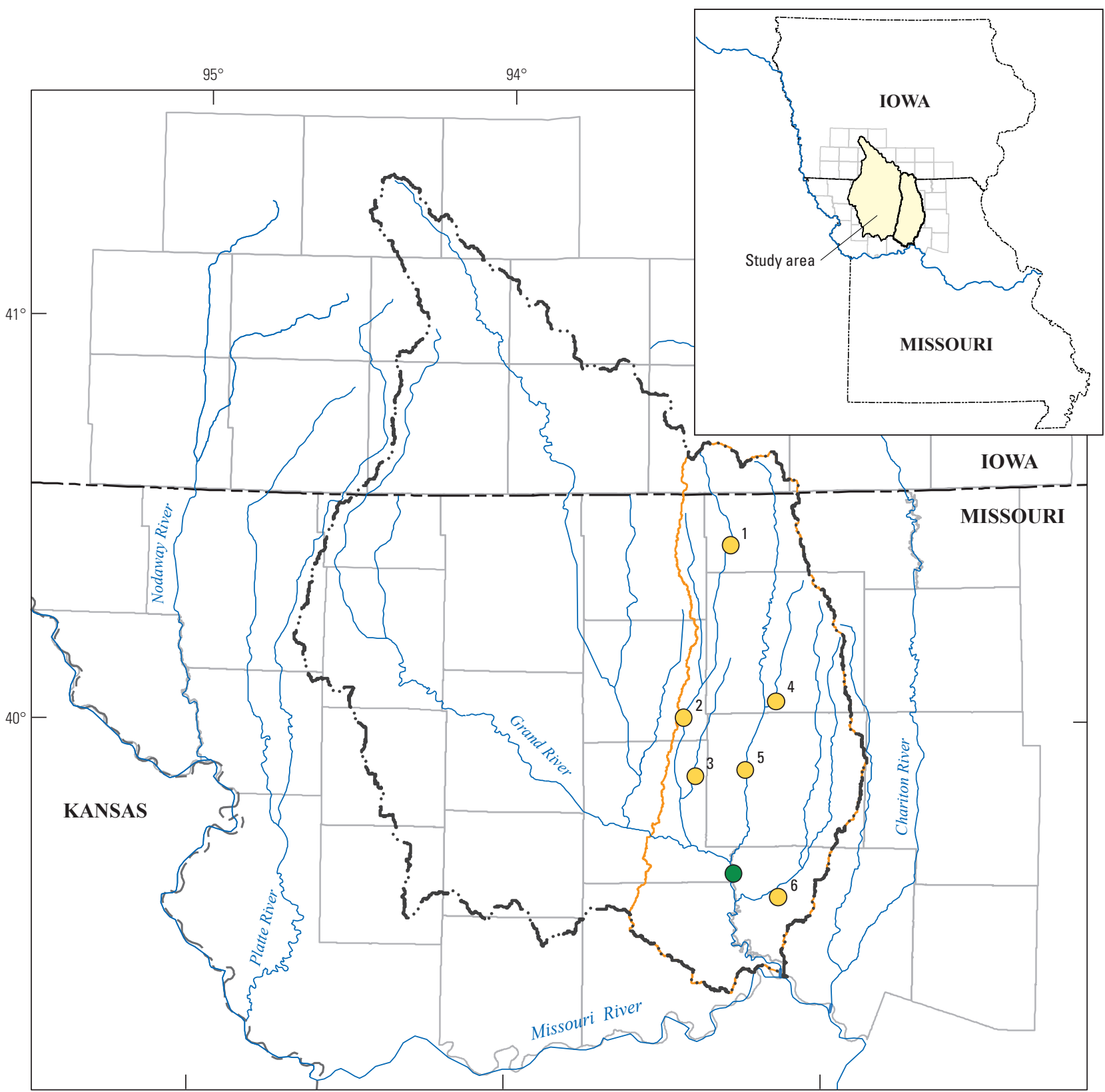

Base from U.S. Geological Survey digital data, 1:2,220,000, 2015 Universal Transverse Mercator projection, Zone $15 \mathrm{~N}$.

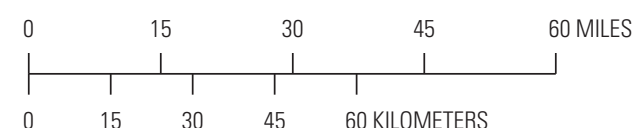

\section{EXPLANATION}

\section{County boundary}

Grand River watershed boundary

Lower Grand River hydrologic unit boundary $\bigcirc^{1}$ Mississippi River Basin Healthy Watersheds Initiative site and identifier (table 1)

U.S. Geological Survey long-term ambient water-quality Grand River near Sumner, Missouri (site number 06902000)

Figure 1. Locations of U.S. Geological Survey water-quality collection sites in the Lower Grand River hydrologic unit, Missouri and lowa. 


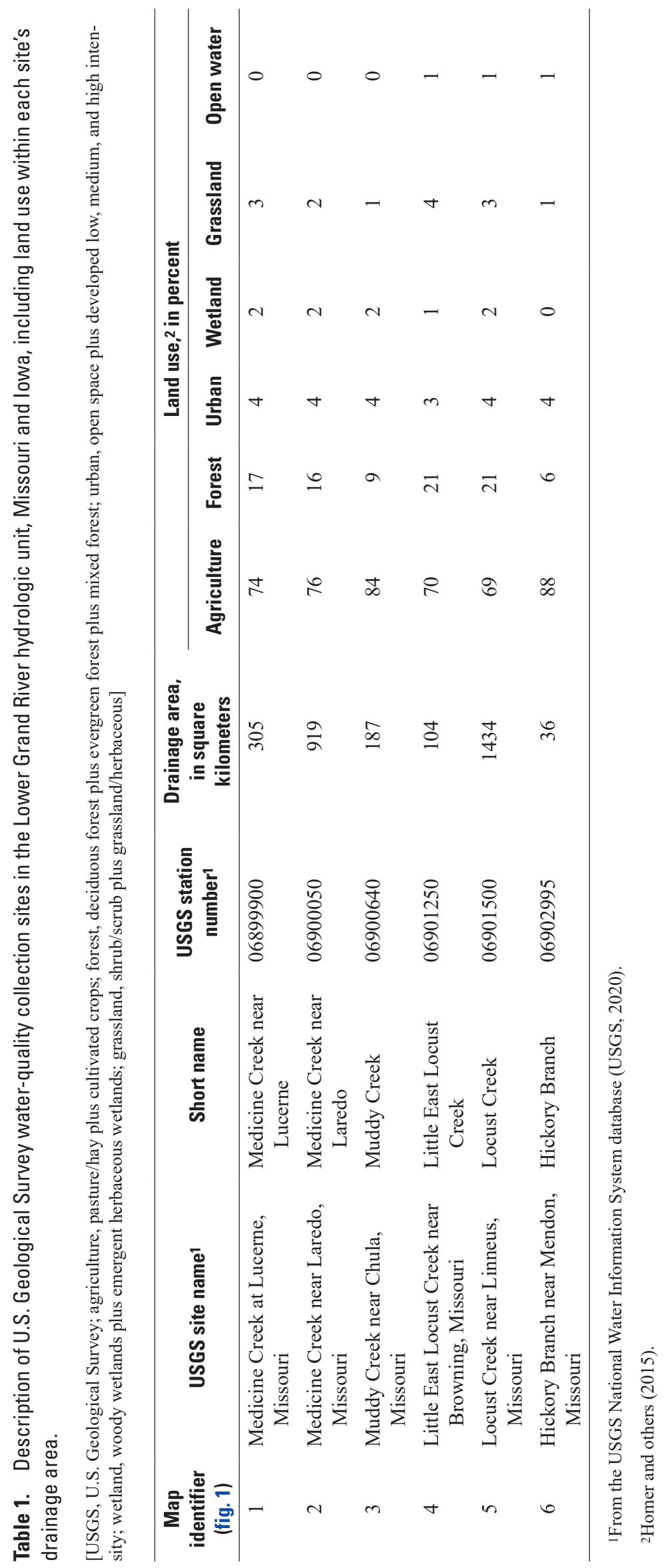




\section{Periphyton Sample Collection}

Periphyton samples were collected during the summer (July through September) from submerged rocks (epilithic sample), when available, or sand-sized particles (epipsammic sample) at each site (Moulton and others, 2002). An epipsammic sample was collected only when enough rocks were not available for an epilithic sample. Epilithic and epipsammic samples result in a composited periphyton sample representing a known surface area at each site, allowing for sample comparability.

Epilithic samples were collected using the "top-rock scrape" method or methods like those described for the SG-92 sampler (Hambrook-Berkman and Canova, 2007; Moulton and others, 2002). Methods described for the SG-92 sampler were modified by using a piece of polyvinyl chloride pipe fitted with a rubber gasket having a diameter of 5.00 centimeters (fig. $2 A$ ), as opposed to the described syringe. Epilithic samples were collected from about 10 rocks at each site depending on availability. Rocks for the "top-rock scrape" method were chosen from multiple areas without prejudgment of selection. Rocks with a flat area that was at least as large as the polyvinyl chloride sampler were selected from multiple areas for the modified SG-92 method to allow for a precise sample and an accurate determination of the sampled area. Scrape samples from each rock were composited into a single sample representing a known surface area.

Epipsammic samples were collected using the inverted petri dish method (Hambrook-Berkman and Canova, 2007). Samples were collected by gently pressing an inverted petri dish with a diameter of 5.97 centimeters into the streambed sediment, using care to remove air bubbles before pressing into substrate and to not disturb the sediment within the sample area. A spatula or the flat side of the petri lid was gently slid under and pressed firmly against the inverted petri dish (fig. 2B). The sample was gently lifted from the water column and rinsed into a sample container using stream water. Epipsammic samples were collected from about 10 sand substrate areas at each site, with additional samples collected if the algae density seemed low to ensure a large enough sample size, and each sand sample was composited into a single sample representing a known surface area.

\section{A}

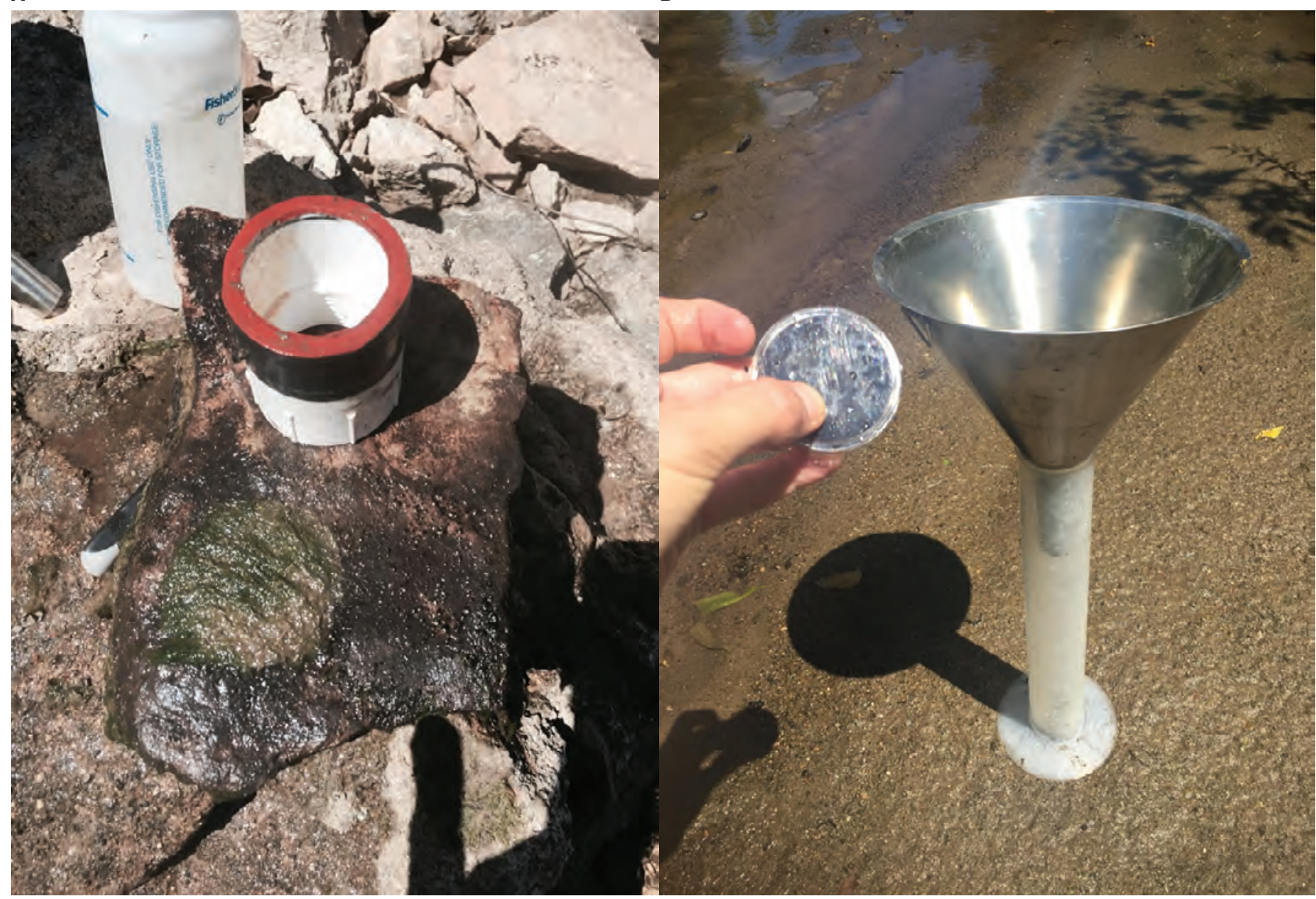

Figure 2. Periphyton sample collection at water-quality collection sites in the Lower Grand River hydrologic unit, Missouri and lowa. $A$, an epilithic sample. $B$, an epipsammic sample. 
Composite periphyton samples were split for a biomass and a periphyton community sample. The composite sample bottle was shaken vigorously before biomass samples were collected using methods described in Hambrook-Berkman and Canova (2007) and Moulton and others (2002) and analyzed at the USGS National Water Quality Laboratory for AFDM and chlorophyll concentrations. Periphyton community samples were processed by preserving 90 milliliters of a sample with 10 milliliters of a 9 to 1 ratio of Lugol's iodine to acetic acid solution for taxonomic identification and determination of biovolume and cell density at the Philadelphia Academy of Natural Sciences (Philadelphia, Pennsylvania; 2011 through 2013) or BSA Environmental Services (Beachwood, Ohio; 2014 through 2018). AFDM represent the total organic weight of the sample and can include the biomass of bacteria, fungi, small fauna, and detritus (Barbour and others, 1999). Chlorophyll is the primary photosynthetic pigment of periphyton (Barbour and others, 1999; MacCoy, 2004; Rasmussen and others, 2009). Biovolume and cell densities are determined from community samples by identifying, counting, and measuring algal cells, which is more costly and labor and time intensive than AFDM or chlorophyll analyses. Biovolume is the volume of cells per unit area, and cell density represents the total number of cells per unit area without regard to cell size. Therefore, biovolume is a better indicator of total periphyton biomass than cell density. AFDM, chlorophyll, and biovolume can be good indicators of overall periphyton biomass (Barbour and others, 1999; MacCoy, 2004; Rasmussen and others, 2009).

Periphyton AFDM and chlorophyll samples were collected 1-5 times annually, and community samples were generally collected annually except during 2015 because there was not a two-week period without substantial streamflow increases, which is necessary to avoid bias from scouring effects. Also, periphyton AFDM samples were not collected at Hickory Branch in 2018 because there was no streamflow during the time of sample collection.

\section{Quality Assurance and Quality Control}

Blank and replicate samples were collected with field samples throughout the year at these sites, and all samples, including those that were not collected with periphyton, were included in quality-assurance and quality-control analyses. In total, 30 blank samples were collected, and 95 percent of sample concentrations were less than the laboratory reporting limits. Concentrations that were not less than the reporting limits were determined for total phosphorus, dissolved nitrate plus nitrite, ammonia, nitrite, and dissolved phosphorus. Five ammonia concentrations were greater than the reporting limit ( 0.01 milligram per liter $[\mathrm{mg} / \mathrm{L}])$; however, four of those sample concentrations were at the reporting limit, and the other sample was $0.02 \mathrm{mg} / \mathrm{L}$. One of the blank samples had an ammonia concentration of $0.003 \mathrm{mg} / \mathrm{L}$, and the reporting limit was $0.001 \mathrm{mg} / \mathrm{L}$. Four concentrations of dissolved phosphorus were greater than the reporting limit $(0.004 \mathrm{mg} / \mathrm{L})$. The greatest dissolved phosphorus concentration of these blank samples was $0.051 \mathrm{mg} / \mathrm{L}$; however, the total phosphorus concentration of this blank sample was less than the reporting limit, no other constituents had concentrations greater than their reporting limits, and the dissolved phosphorus concentration of the field sample was less than the reporting limit. Having a dissolved phosphorus concentration greater than the total phosphorus concentration is problematic and having a field sample concentration less than the blank sample concentration is unusual, and more likely, the values for the blank and field samples were switched. The other three dissolved phosphorus concentrations that were greater than or equal to the reporting limit $(0.004 \mathrm{mg} / \mathrm{L})$ were $0.11,0.008$, and $0.004 \mathrm{mg} / \mathrm{L}$. These three blank samples also had total phosphorus concentrations that were greater than the reporting limit $(0.004 \mathrm{mg} / \mathrm{L})$ : one concentration was $0.007 \mathrm{mg} / \mathrm{L}$, and two were $0.005 \mathrm{mg} / \mathrm{L}$. These phosphorus concentrations were unusual because the dissolved phosphorus concentrations were greater than the total phosphorus concentrations in two of these samples. Two dissolved nitrate plus nitrite blank sample concentrations were greater than the reporting limit; however, in both of these samples, concentrations of the field samples were less than the reporting limit, and no other blank sample constituents had concentrations greater than their reporting limit, which, again, indicates contamination was unusual or, more likely, the values for the blank and field samples were switched. Although blank sample concentrations were greater than the reporting limit for some constituents, 95 percent were less than the laboratory reporting limits, and most concentrations were not substantially greater than the reporting limit or the concentrations were likely switched with field sample concentrations.

In total, 53 replicate water-quality samples were collected. The greatest average relative percent difference between field and replicate concentrations was for suspended sediment (10 percent). The other water-quality constituents had an average relative percent difference of 6 percent or less, and the lowest average relative percent difference was for total phosphorus ( 3 percent). Overall, water-quality concentrations between field and replicate samples were similar. 
Replicate periphyton samples were also collected, including 30 AFDM, 12 chlorophyll, and 4 community samples. The average relative percent difference between field and replicate samples was 5 percent for AFDM and 6 percent for chlorophyll samples. Because community samples are collected to compare taxa relative abundances and determine sample similarities, replicate samples were compared using MDS, which displays relative likeness among samples by distance, where similar samples are near each other and more dissimilar samples are farther apart. Field and replicate samples that were collected together were closer in proximity than other field samples (fig. 3). This proximity indicates there is a greater relation to each other than to other field samples, and the variability between field and replicate samples is acceptable for community analysis. Expected variability among community samples is not well documented and continued replicate analysis will further the understanding of expected variability among samples.

\section{Periphyton and Water-Quality Sample Analysis}

Water-quality sample concentrations and physical parameters were compared to periphyton samples to explore potential effects on periphyton biomass. Periphyton community compositions were compared among sites and years and were used in ordinary least squares regression models with AFDM and chlorophyll concentrations to explore relations between periphyton biomass and physical and chemical factors. Sample information and water-quality concentrations were used in MDS to visually display effects on sample similarities. Community sample attributes were calculated using taxa metrics, and water-quality factors were compared to the overall biomass, taxa abundance, and community composition.

\section{Water-Quality Sample Concentrations}

Water-quality sample concentrations that were collected with periphyton were used to describe conditions during periphyton sampling. The average, maximum, minimum, range, and standard deviation were calculated for each sampled constituent at each site (tables 2,3). Ammonia concentrations were compared to national recommended criteria, nitrate and nitrite were compared to their drinking water maximum contamination limit (MCL), total nitrogen was compared to acceptable concentration ranges, and total phosphorus was compared to appropriate instream reference levels. The proportions of specific forms of nitrogen and phosphorus were discussed to better understand the primary sources of total nitrogen and phosphorus. Nutrient concentrations are potentially related to periphyton biomass and taxa composition.

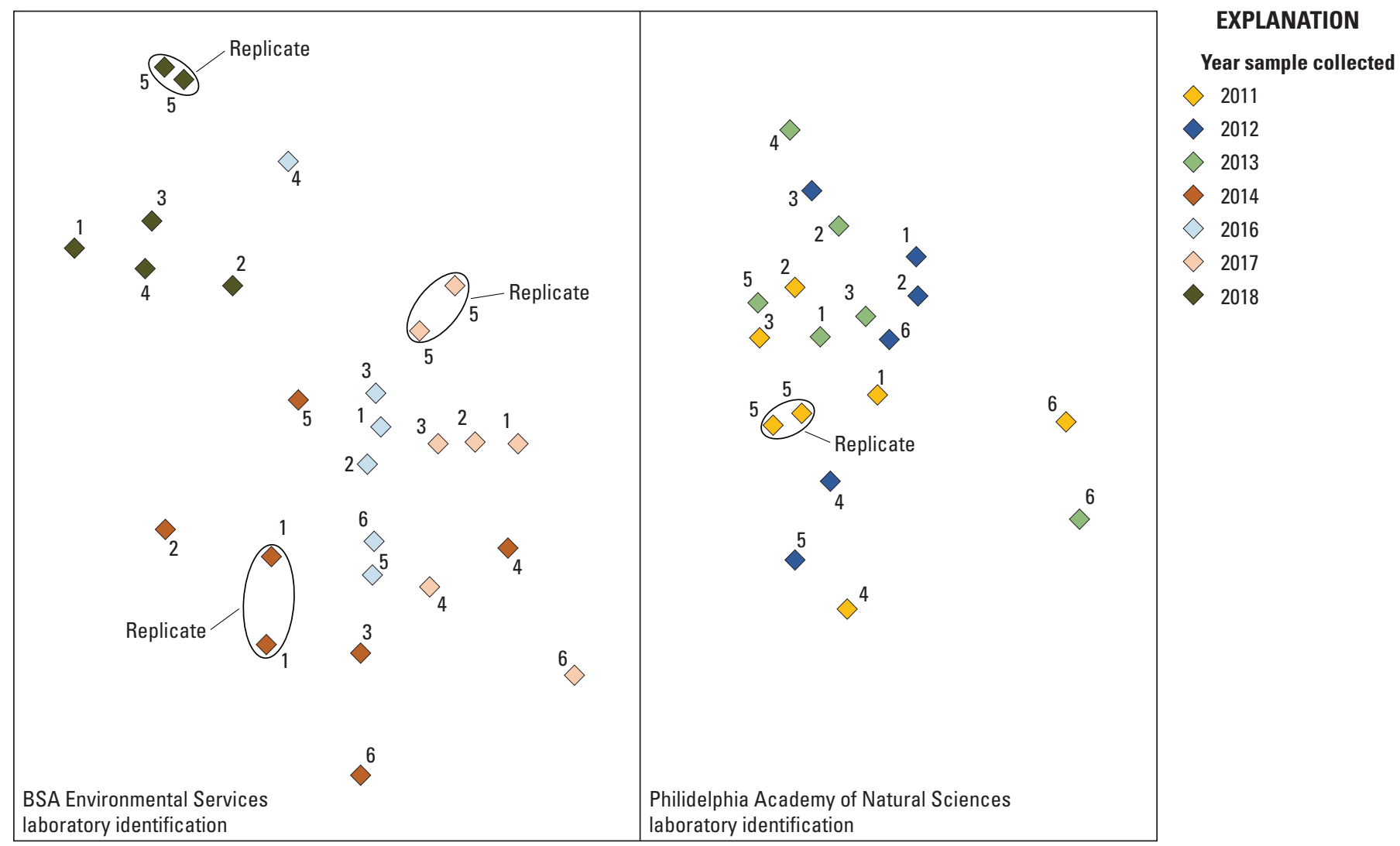

Figure 3. Nonparametric multidimensional scaling plot of periphyton taxa biovolume with year and identifying laboratory indicated. 


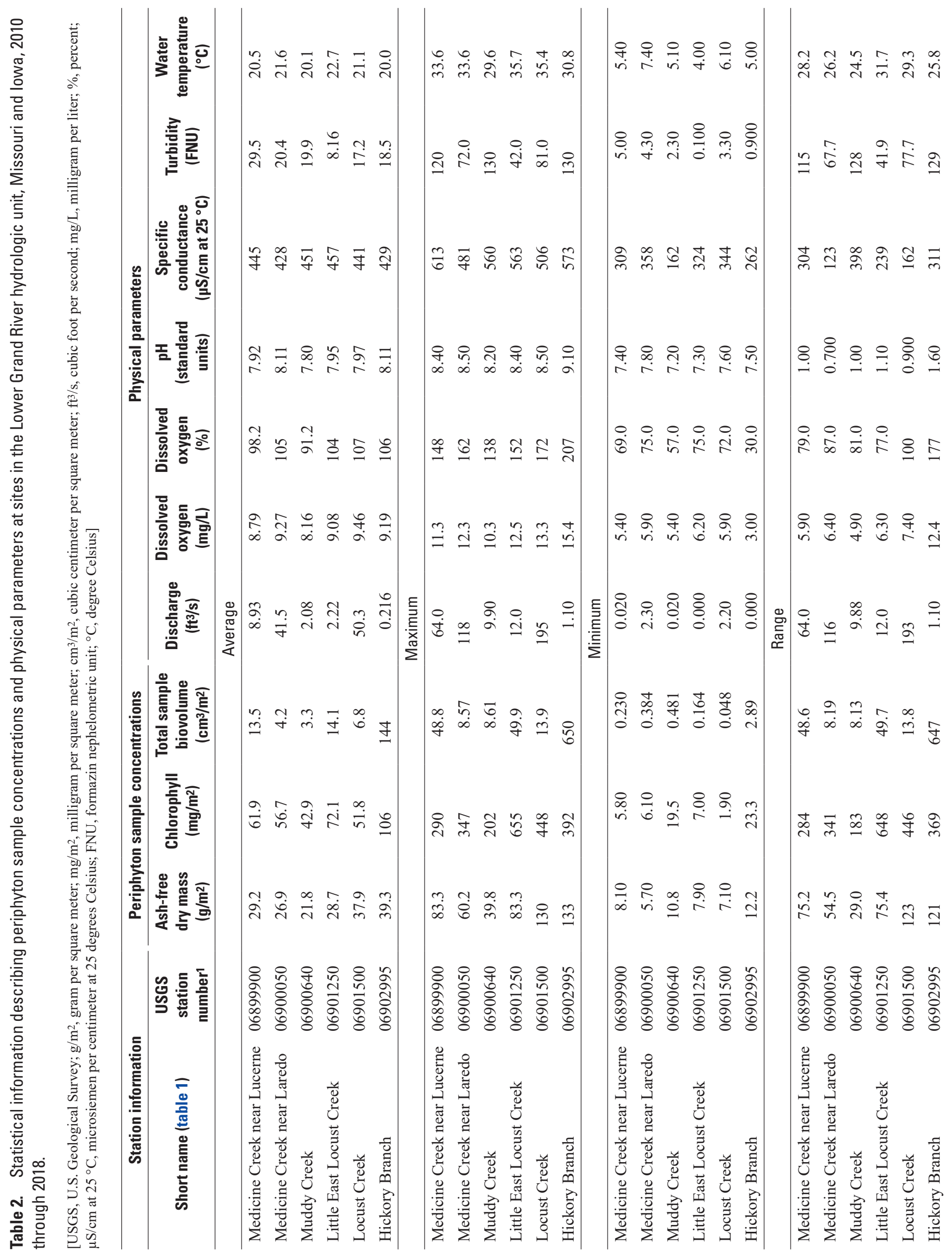




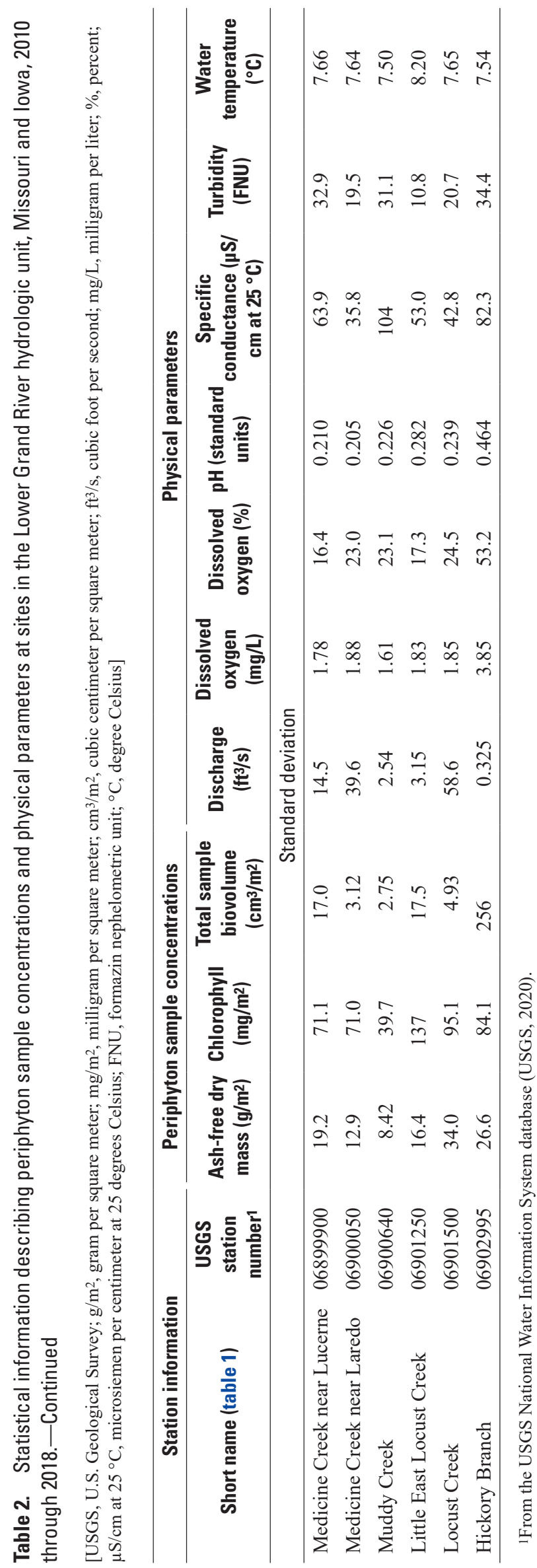

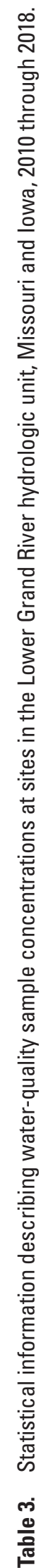

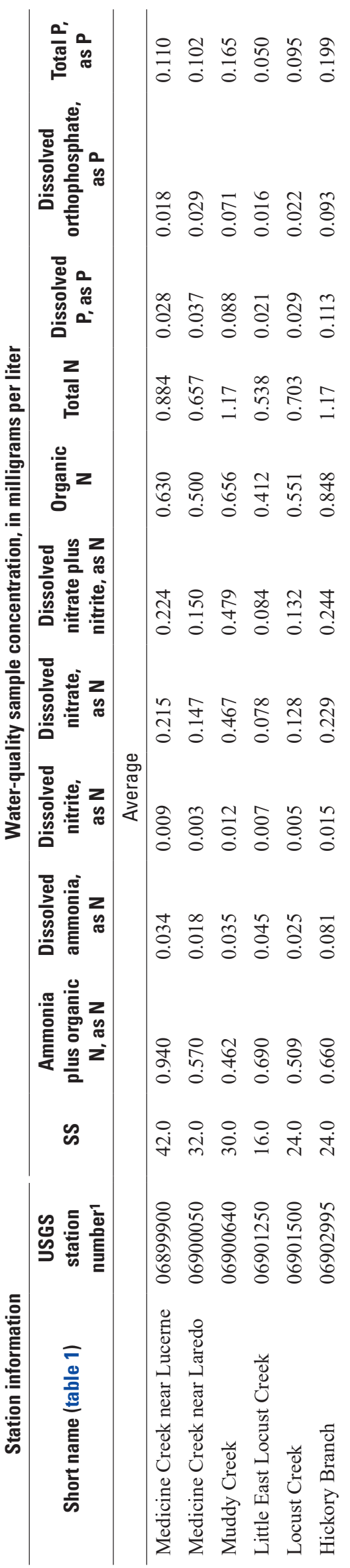




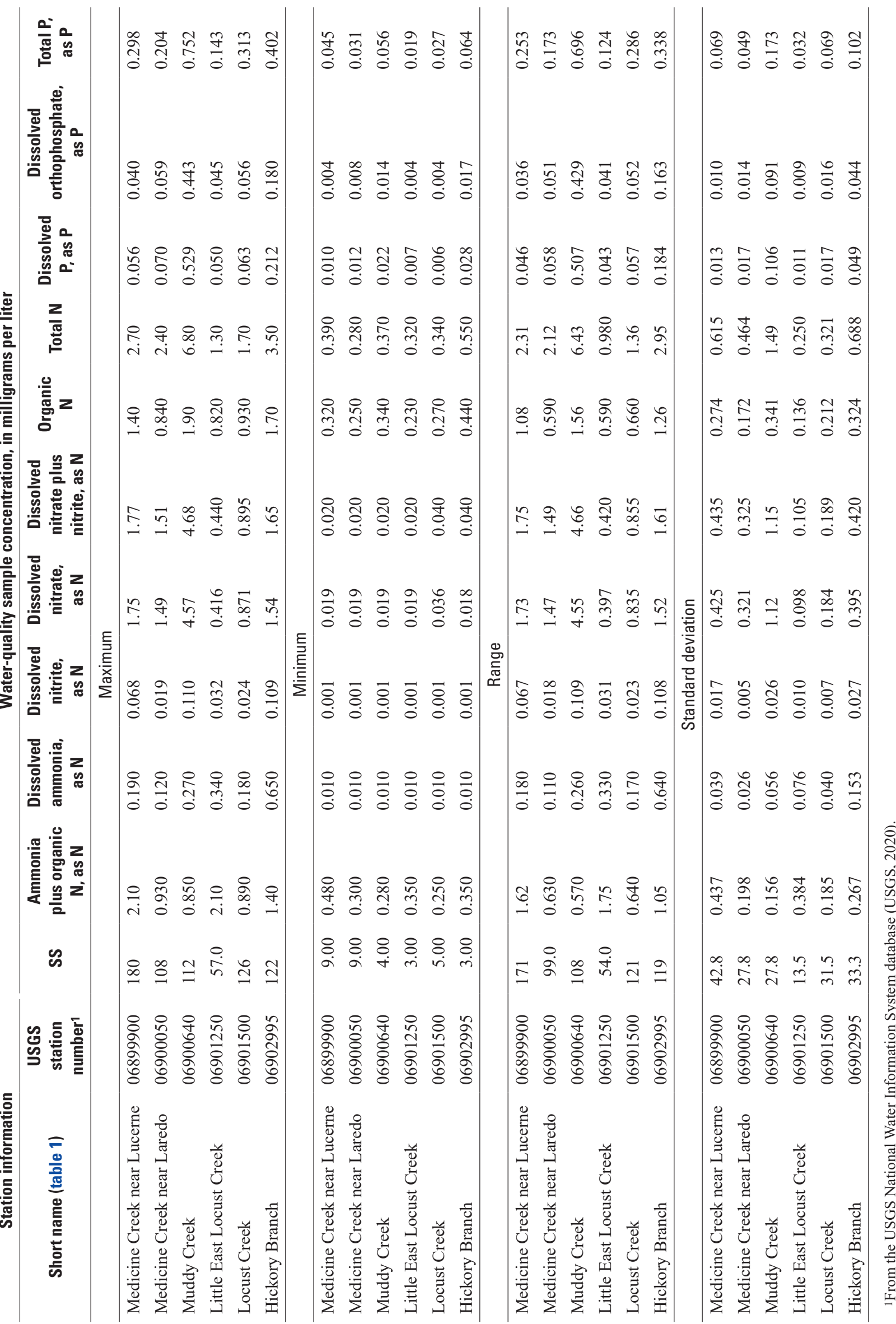




\section{Periphyton Biomass and Water-Quality Relations}

AFDM and chlorophyll concentrations were used to compare periphyton biomass among sites and years and were used in ordinary least squares regression models to determine relations with physical and chemical factors. Chlorophyll concentrations that exceed $100 \mathrm{mg} / \mathrm{m}^{2}$ have been described as nuisance algal conditions (Horner and others, 1983; Lohman and others, 1992; Rasmussen and others, 2009; Welch and others, 1988), and sample chlorophyll concentrations were compared to this threshold. AFDM and chlorophyll concentrations were used in ordinary least squares regression models with water-quality sample concentrations to explore relations. Relations were determined significant if the statistical probability values ( $p$-values) were less than 0.05 , indicating AFDM or chlorophyll concentrations increase or decrease significantly as physical or chemical factors increase or decrease. The coefficient of determination $\left(R^{2}\right)$ was used to determine if significant relations were strong $\left(R^{2}\right.$ greater than 0.80 ). All samples grouped together and samples from each site individually were used in ordinary least squares regression models to explore relations between periphyton biomass and physical and chemical factors.

\section{Periphyton Community Composition}

The periphyton community composition was described to qualitatively assess the ecological health. When environments are degraded, communities are often dominated by a few taxa that are tolerant to the degraded environment conditions. Community attributes can be used to assess ecological health including taxa richness (total number of taxa identified), number of taxa per algal division, dominant algal type, relative biovolume of dominant species, and taxa tolerances of common species.

\section{Water-Quality Effects on Periphyton Community Similarities}

Sample similarities were determined using a two-dimensional MDS plot with taxa biovolumes (micrometer per square centimeter) from community samples. MDS is a nonparametric ordination technique that displays relative likeness among samples by distances, where similar samples are near each other and more dissimilar samples are farther apart. Biovolumes of taxa were square root transformed with Bray-Curtis resemblance matrix calculations (Clarke and others, 2014). The MDS plot was visually compared to site information and water-quality sample concentrations by changing the symbology of the plot to display factors that may affect sample similarities including site, year, month, and tertials of total nitrogen, total phosphorus, suspended sediment, chlorophyll, and AFDM concentrations. Changing the symbology of the MDS plot to display factors does not affect distances among sample points, but allows for a visual comparison between community sample similarities and sample factor similarities; if sample factors group similar to community samples, then the sample factor likely affects the community structure.

\section{Periphyton Community Attributes and Taxa Metrics}

Periphyton community attributes were calculated using taxa metrics to describe community characteristics. Taxa biovolumes and cell densities were determined from community samples. Biovolume is the volume of an identified taxa per unit area, and cell density is the total number of cells per unit area, which does not account for the size of the cells. Relative biovolumes of taxa were used instead of cell density because it more accurately relates to the overall taxa biomass. Community attributes and taxa metrics were described in Porter (2008). Taxa metrics are described for diatoms, soft algae, or both. These sites are located within the central and western plains region, and two regional indicators of nutrient concentrations and trophic condition were used (Porter, 2008). National indicators included 8 indicators of organic enrichment; 9 indicators of $\mathrm{pH}$, salinity, specific conductance, and chloride concentrations; and 4 indicators of microhabitat traits, suspended-sediment, and calcium concentrations. Differences between laboratory-provided periphyton nomenclature and nomenclature in Porter (2008) were resolved by reviewing applicable literature (Guiry and Guiry, 2020; Wehr and others, 2015). Ambiguous (taxa identified to a greater taxonomic level than genus) and rare (present in two or less samples or less than 1 percent of any sample) taxa were not deleted. Taxa metrics were not described for all identified taxa; therefore, community metrics may not equal 100 percent. Although, not all taxa have described metrics available, information from taxa that are described can be used to evaluate factors affecting taxa abundances and community composition. 


\section{Water-Quality Sample Concentrations}

Physical parameters were measured, and water-quality samples were collected with periphyton samples (tables 2, 3 ). Samples were collected during the summer and at least 2 weeks after substantial streamflow increases when streamflow was low and close to baseflow. Krempa and Flickinger (2017) determined that nutrient concentrations at these sites are generally the lowest during these conditions and that concentrations increase with streamflow. Average water-quality sample concentrations during periphyton sampling were lower than the average concentrations of samples collected throughout the entire year. Samples were qualified as less than reporting limits or estimated according to standard laboratory procedures (Childress and others, 1999), and many constituents had concentrations less than reporting limits. Because the concern in the Lower Grand River is excessive nutrients, the maximum concentrations, or reporting levels, were used for values reported as less than to avoid underestimating concentrations. Water-quality sample concentrations that were collected with periphyton are discussed to describe conditions during periphyton sampling.

\section{Suspended Sediment}

Suspended sediment can bond to phosphorus and harmful contaminants (such as heavy metals), reduces light availability, and can settle on streambeds smothering habitat necessary for periphyton attachment and macroinvertebrate and fish foraging, refugia, breeding, and egg laying. Suspended-sediment sample concentrations ranged from 3 to $180 \mathrm{mg} / \mathrm{L}$ (table 3). The greatest concentrations were at Medicine Creek near Lucerne, which had the greatest average $(42 \mathrm{mg} / \mathrm{L})$, maximum $(180 \mathrm{mg} / \mathrm{L})$, and minimum $(9 \mathrm{mg} / \mathrm{L})$ concentrations. Little East Locust Creek had the lowest average $(16 \mathrm{mg} / \mathrm{L})$, maximum $(57 \mathrm{mg} / \mathrm{L})$, and minimum ( $3 \mathrm{mg} / \mathrm{L})$ concentrations. Water-quality standards for East Fork Medicine Creek, which includes Medicine Creek near Lucerne, were exceeded because of sediment, and a total maximum daily load was established (EPA,
2006). Medicine Creek near Laredo also had a minimum concentration of $9 \mathrm{mg} / \mathrm{L}$ (table 3). Little East Locust Creek had the lowest maximum $(57 \mathrm{mg} / \mathrm{L})$, minimum $(3 \mathrm{mg} / \mathrm{L})$, and average $(16 \mathrm{mg} / \mathrm{L})$ concentrations. Hickory Branch also had a minimum concentration of $3 \mathrm{mg} / \mathrm{L}$. All sites, except Little East Locust Creek, had maximum concentrations greater than $100 \mathrm{mg} / \mathrm{L}$ (table 3). Suspended-sediment concentrations in the Lower Grand River had large variability among years, especially because samples were collected during low flow, but concentrations were similar among sites. The greatest concentrations were at Medicine Creek near Lucerne, which exceeded water-quality standards because of sediment, and the lowest concentrations were at Little East Locust Creek.

\section{Nitrogen Species}

Ammonia is a form of nitrogen that is directly toxic to aquatic life, unlike other forms of nitrogen, which contribute to eutrophication but are not directly toxic (EPA, 2013a). Ammonia is present in agricultural land runoff, wastewater effluent, and animal waste. In 2003, the EPA set national recommended ambient water-quality criteria for protecting freshwater organisms from potential effects of ammonia. The acute recommendation was described as $17 \mathrm{mg} / \mathrm{L}$ total ammonia as nitrogen, and the chronic ambient water-quality criteria was described as $1.9 \mathrm{mg} / \mathrm{L}$ total ammonia as nitrogen (EPA, 2013a). No dissolved ammonia as nitrogen concentrations were greater than the ambient water-quality criteria in samples collected with periphyton sampling (tables 3) or in any samples collected during 2010 through 2018 (USGS, 2020); however, the criteria are for total ammonia, and dissolved ammonia as nitrogen concentrations are less than total ammonia concentrations. Average dissolved ammonia as nitrogen concentrations were low (ranged from 0.018 to $0.081 \mathrm{mg} / \mathrm{L}$ ), 50 percent of dissolved ammonia samples were at or less than the laboratory reporting level of $0.01 \mathrm{mg} / \mathrm{L}$, and the greatest concentration of dissolved ammonia as nitrogen was $0.65 \mathrm{mg} / \mathrm{L}$ at Hickory Branch in October 2013 (table 3; USGS, 2020). Ammonia concentrations in the Lower Grand River do not indicate excessive ammonia is an issue during low-flow conditions. 
Nitrate and nitrite are inorganic forms of nitrogen that occur naturally and are in urban and agricultural fertilizers. Excessive nitrate and nitrite in drinking water can cause adverse human-health effects including restricting oxygen transport in the bloodstream (Land and others, 1998), causing infant methemoglobinemia, cancer, and adverse reproductive outcomes (National Research Council, 1995; Ward and others, 2018); and nitrite in aquatic systems is toxic to fish (Kroupova and others, 2005; Jensen, 2003). The drinking-water MCL of nitrite is $1 \mathrm{mg} / \mathrm{L}$, and the MCL of nitrate is $10 \mathrm{mg} / \mathrm{L}$ (EPA, 2020). No samples had concentrations of dissolved nitrite or nitrate greater than their MCLs (table 3). Most nitrites in the environment are quickly converted to nitrate because nitrate is more stable, but nitrates are converted to nitrites in the human body. Therefore, nitrate and nitrite human-health effects are additive. Total dissolved nitrate plus nitrite concentrations did not exceed the MCL for nitrate. In fact, in all samples collected throughout the entire year at these sites during 2010 through 2018, only one concentration of dissolved nitrate plus nitrite at Muddy Creek in May 2018 was reported at the MCL for nitrate $(10 \mathrm{mg} / \mathrm{L})$. No other concentrations of dissolved nitrate or nitrite were at or above the MCLs (USGS, 2020). Almost one-half of samples collected with periphyton (43 percent) had dissolved nitrite concentrations less than or equal to the reporting level $(0.001 \mathrm{mg} / \mathrm{L})$, and the greatest concentration was $0.110 \mathrm{mg} / \mathrm{L}$ at Muddy Creek in September 2012. Overall, in samples collected with periphyton dissolved nitrate and nitrite concentrations were low. Dissolved nitrite concentrations were not high enough to be toxic to fish, and dissolved nitrate plus nitrite concentrations were not high enough to be directly toxic to humans. However, nitrate and nitrite contribute to total nitrogen concentrations, which can lead to eutrophication, excessive plant and algae growth, drinking-water taste and odor problems, low dissolved-oxygen concentrations, and harmful algal blooms.

Organic nitrogen also contributes to total nitrogen concentrations and can enter waterways from wastewater effluent and livestock manure. In total, 40 percent of organic nitrogen samples were less than reporting levels, which ranged from 0.230 to $1.4 \mathrm{mg} / \mathrm{L}$. Average concentrations ranged from 0.412 to $0.848 \mathrm{mg} / \mathrm{L}$, the greatest concentration was $1.9 \mathrm{mg} / \mathrm{L}$ at Muddy Creek during September 2012, and minimum concentrations were less than $0.5 \mathrm{mg} / \mathrm{L}$ at all sites (table 3; USGS, 2020). Organic nitrogen concentrations were greater than dissolved ammonia in all samples and greater than dissolved nitrate plus nitrite in 94 percent of samples. Organic nitrogen generally was the greatest source to total nitrogen.

Total nitrogen includes ammonia, nitrate, nitrite, and organic nitrogen; and elevated nitrogen concentrations can lead to eutrophication, excessive plant and algae growth, drinking-water taste and odor problems, low dissolved-oxygen concentrations, and harmful algal blooms. The reporting level was used for concentrations reported as less than the reporting level to avoid underestimating concentrations, and 52 percent of samples were less than the reporting level. Average total nitrogen concentrations ranged from 0.538 to $1.17 \mathrm{mg} / \mathrm{L}$. Maximum concentrations were greater than $1 \mathrm{mg} / \mathrm{L}$ at all sites, and the greatest concentration was $6.8 \mathrm{mg} / \mathrm{L}$ at Muddy Creek in September 2012. Minimum concentrations were $0.550 \mathrm{mg} / \mathrm{L}$ or less (table 3; USGS, 2020). According to the EPA, acceptable total nitrogen concentrations range from 2 to $6 \mathrm{mg} / \mathrm{L}$ (EPA, 2013b). Concentrations greater than $2 \mathrm{mg} / \mathrm{L}$ were determined at all sites except Little East Locust Creek and Locust Creek, and a concentration greater than $6 \mathrm{mg} / \mathrm{L}$ was determined at Muddy Creek. These samples were collected during periods of low flow when nitrogen concentrations are lower than during high-flow and runoff conditions (Krempa and Flickinger, 2017), which indicates total nitrogen concentrations likely are often greater than acceptable concentrations at these sites. The primary land use in the Lower Grand River is agriculture, and nitrogen inputs are likely dominated by agricultural sources.

\section{Phosphorus Species}

Phosphorus is an essential nutrient that enters aquatic systems from rocks, sediments, fertilized lawns and croplands, animal manure, water-treatment plants, phosphate detergents, and decomposition of organic matter. Excessive phosphorus, like nitrogen, can cause eutrophication and subsequent problems. Phosphorus can bind to particulates or is dissolved. Orthophosphate is inorganic phosphorus that is readily absorbed by plants and algae. Dissolved phosphate, dissolved orthophosphate, and total phosphorus concentrations were determined.

Phosphorus that enters waterways during runoff events is generally bound to sediments, and dissolved forms are more likely associated with groundwater (Schilling and others, 2017). Average dissolved phosphate concentrations ranged from 0.021 to $0.113 \mathrm{mg} / \mathrm{L}$, the maximum concentration was $0.529 \mathrm{mg} / \mathrm{L}$ at Muddy Creek in September 2012, and minimum concentrations were less than $0.03 \mathrm{mg} / \mathrm{L}$ at all sites (table 3; USGS, 2020). Dissolved phosphate concentrations ranged from 5 to 86 percent of total phosphorous, and concentrations were less than one-half of the total phosphorous in most samples (70 percent). These samples were collected during low flow, not during runoff conditions, and more phosphorus was bound to sediment than dissolved phosphate in most samples. This bonding indicates field runoff or resuspension of bank or bed sources are likely a large source of phosphorus because phosphorus bound to sediment is more likely from runoff events than groundwater. 
Dissolved orthophosphate is an inorganic form of dissolved phosphate that is readily absorbed by plants and algae and can enter waterways from sewage and urban and agricultural fertilizers. Average dissolved orthophosphate concentrations ranged from 0.016 to $0.093 \mathrm{mg} / \mathrm{L}$, the maximum concentration was $0.0443 \mathrm{mg} / \mathrm{L}$ at Muddy Creek in September 2012, and minimum concentrations were less than $0.02 \mathrm{mg} / \mathrm{L}$ at all sites (table 3; USGS, 2020). Concentrations of dissolved orthophosphate were low, which was expected during low-flow conditions, and were likely greater during high-flow and runoff conditions.

Total phosphorus is often the nutrient that is limiting plant and algae growth and, like total nitrogen, can lead to eutrophication, excessive plant and algae growth, drinking-water taste and odor problems, low dissolved-oxygen concentrations, and harmful algal blooms. Average total phosphorus concentrations from samples collected with periphyton ranged from 0.050 to $0.199 \mathrm{mg} / \mathrm{L}$, the maximum concentration was $0.752 \mathrm{mg} / \mathrm{L}$ at Muddy Creek in September 2012, and minimum concentrations were less than $0.064 \mathrm{mg} / \mathrm{L}$ at all sites (table 3; USGS, 2020). Neither a drinking-water MCL nor a national water-quality criterion for total phosphorus have been determined, but the EPA states that appropriate instream reference concentrations may range from 0.01 to $0.075 \mathrm{mg} / \mathrm{L}$, depending on the ecoregion (EPA, 2019). All concentrations of total phosphorus from samples collected with periphyton were greater than the low reference condition $(0.01 \mathrm{mg} / \mathrm{L}), 57$ percent of samples were greater than the high reference level $(0.075 \mathrm{mg} / \mathrm{L})$, and at least three samples at each site were greater than the high reference level. Most of the samples collected throughout the entire year at these sites from 2010 through 2018 (72 percent) had total phosphorus concentrations greater than the high reference level (USGS, 2020), which indicates total phosphorus concentrations are elevated throughout most the year. Phosphorus is often the nutrient limiting plant and algae growth, and these elevated concentrations likely contribute to eutrophic conditions and subsequent problems. The primary land use in the Lower Grand River is agriculture, and phosphorus inputs are likely dominated by agricultural sources.

\section{Water-Quality Sample Summary}

Measured constituent concentrations were generally elevated at these sites. The greatest sample concentrations were from Muddy Creek in September 2012 for all sampled constituents except dissolved ammonia, when the sample from Hickory Branch in September 2013 had the greatest concentration, followed by the Muddy Creek September 2012 sample (table 3; USGS, 2020). Hickory Branch and Muddy Creek samples were consistently among the greatest sample concentrations, especially in September 2012 at Muddy Creek and June or October 2013 at Hickory Branch.
Total nitrogen includes ammonia, nitrate, nitrite, and organic nitrogen; and elevated concentrations can lead to eutrophication, excessive plant and algae growth, drinking-water taste and odor problems, low dissolved-oxygen concentrations, and harmful algal blooms. Ammonia concentrations were less than water-quality criteria and are likely not a problem during these conditions. Dissolved nitrate and nitrite concentrations were not high enough to be directly toxic to humans. Nitrate and nitrite contribute to total nitrogen; however, organic nitrogen generally was the greatest source to total nitrogen. Total nitrogen concentrations were greater than acceptable concentrations described by the EPA.

Total phosphorus includes phosphorus bound to sediment and dissolved phosphates, and elevated phosphorus concentrations can also lead to eutrophication and subsequent problems. Field runoff or resuspension of bank or bed sources is likely a large source because phosphorus bound to sediment is more likely from runoff events than groundwater, and dissolved phosphate concentrations were less than one-half of the total phosphorous concentration in most samples. Concentrations of dissolved orthophosphorus were low, which was expected during low-flow conditions, and were likely greater during high-flow and runoff conditions. Total phosphorus concentrations were greater than described low-reference condition concentrations in all samples, and more than 50 percent of the sample concentrations were greater than the high reference level. Samples were collected during low-flow conditions when nutrients are less than during high-flow and runoff conditions; elevated nutrient concentrations during these conditions indicate nutrient concentrations are likely elevated throughout most of the year. Agriculture is the primary land use in the Lower Grand River and is likely a primary source of nutrients and sediments.

\section{Periphyton Biomass and Community Structure}

Periphyton are good indicators of water-quality and ecological health. They are the base of the stream system food web, they link physical and chemical parameters to higher trophic levels, and they have short life cycles allowing them to respond rapidly to physical and chemical changes. Periphyton species' tolerances, preferences, optimum ranges, and ability to tolerate physical and chemical hardships are described for many water-quality constituents, physical parameters, and chemical concentrations (Porter, 2008). Many factors affect periphyton biomass and species composition including nutrient and light availability, water temperature, grazing pressure, nutrient ratios, and physical and chemical disturbances. 


\section{Periphyton Biomass and Water-Quality Relations}

Total periphyton biomass is important because excessive amounts of periphyton can lead to low dissolved-oxygen concentrations that kill fish and other aquatic life, can reduce recreational opportunities such as boating, swimming, and fishing, and can increase costs for irrigation and drinking-water treatment. AFDM represents the total organic weight of the sample, and chlorophyll is the primary photosynthetic pigment of periphyton (Barbour and others, 1999; MacCoy, 2004; Rasmussen and others, 2009). Both AFDM and chlorophyll concentrations are good indicators of total periphyton biomass.

Average AFDM concentrations ranged from 21.8 to 37.9 grams per square meter ( $\mathrm{g} / \mathrm{m}^{2}$; table 2; Krempa, 2020). The greatest AFDM concentration was at Hickory Branch in September $2017\left(133 \mathrm{~g} / \mathrm{m}^{2}\right)$ followed by Locust Creek in September $2011\left(130 \mathrm{~g} / \mathrm{m}^{2}\right)$, and the greatest variability was at Locust Creek followed by Hickory Branch (table 2; fig. 4; Krempa, 2020). The least variability in AFDM was at Muddy Creek, which also had the lowest maximum concentration $\left(39.8 \mathrm{~g} / \mathrm{m}^{2}\right)$.

Average chlorophyll concentrations ranged from 42.9 to $106 \mathrm{mg} / \mathrm{m}^{2}$ among sites (table 2). The greatest chlorophyll concentration was $655 \mathrm{mg} / \mathrm{m}^{2}$ at Little East Locust Creek in September 2012 (fig. 4; Krempa, 2020). The maximum chlorophyll concentrations were collected in September 2012 at all sites, except Medicine Creek near Lucerne, where the greatest concentration was in April $2016\left(290 \mathrm{mg} / \mathrm{m}^{2}\right.$, table 2; fig. 4; Krempa, 2020). Samples collected in April 2016 had the second greatest chlorophyll concentrations at all the other sites. The lowest chlorophyll concentration was at Locust Creek in May $2011\left(1.9 \mathrm{mg} / \mathrm{m}^{2}\right)$. Muddy Creek had the least variability in chlorophyll concentrations, and Little East Locust Creek had the greatest variability (table 2; fig. 4; Krempa, 2020).

AFDM and chlorophyll concentrations were used in ordinary least squares regression models to analyze relations between periphyton biomass and water-quality constituents. Relations were determined significant if $p$-values were less than 0.05 ; relations were considered strong if $R^{2}$ was greater than 0.80 . Ordinary least squares regression models were used for all samples combined and for samples from each site individually for both AFDM and chlorophyll concentrations with water-quality constituents.
Although there were significant relations ( $p$-value less than 0.05 ; table 4 [cells highlighted in gray]) determined between AFDM and chlorophyll with water-quality constituents, no relations were strong $\left(R^{2}\right.$ greater than or equal to 0.80 ; table 4). More significant relations were determined between water-quality constituents and chlorophyll than AFDM. Four significant relations were determined with AFDM: dissolved-oxygen concentration and percent for all samples combined, dissolved-oxygen percent at Muddy Creek, and dissolved ammonia at Locust Creek (table 4). Significant relations determined with chlorophyll include dissolved ammonia for all samples combined, Medicine Creek near Lucerne, Muddy Creek, and Locust Creek; water temperature for all sites combined; dissolved phosphorus at Medicine Creek near Lucerne and Muddy Creek; and dissolved orthophosphate at Medicine Creek near Laredo and Muddy Creek (table 4). Other significant relations were determined at Muddy Creek (pH, specific conductance, turbidity, suspended sediment, ammonia plus organic nitrogen, dissolved ammonia, dissolved nitrite, organic nitrogen, dissolved orthophosphate, total nitrogen, and total phosphorus); however, all relations at this site were highly affected by a single large chlorophyll concentration on September 27, 2012 (table 4; fig. 4; Krempa, 2020). Chlorophyll concentrations at all sites were elevated during this period; however, when this data point is removed from the analysis, the only significant relation at Muddy Creek with chlorophyll is between dissolved-oxygen concentration. Dissolved ammonia had the greatest number of significant relations with chlorophyll ( $p$-value less than 0.05 ; table 4 ), which were determined when all samples were combined, at Medicine Creek near Lucerne, Muddy Creek, and Locust Creek. Ammonia can be directly toxic to aquatic life.

Dissolved ammonia concentrations were not greater than the chronic ambient water-quality criteria (EPA, 2013a); however, this criterion is for total ammonia not dissolved ammonia, which was not determined.

Significant relations between AFDM and chlorophyll with water-quality constituents were determined. A national study determined significant relations between chlorophyll concentrations and nitrate, total nitrogen, total phosphorus, ammonium, dissolved oxygen, discharge, and other physical characteristics (Dodds and others, 2002). Although significant relations were determined at these sites, no relations were strong, which indicates that these factors alone are not good predictors of periphyton biomass at these sites or more data are necessary to understand these relations. Factors affecting 

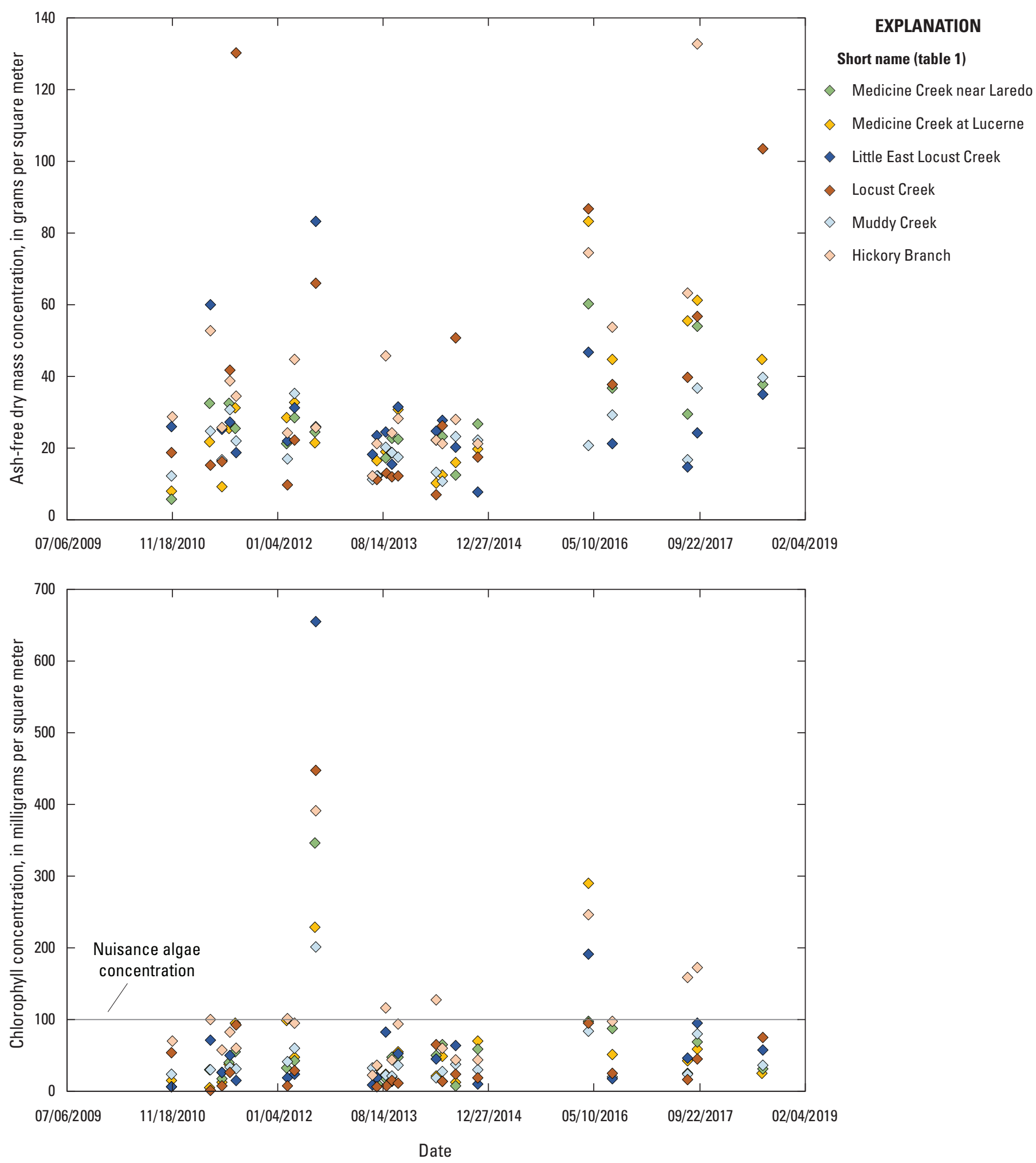

Figure 4. Ash-free dry mass and chlorophyll concentrations at water-quality collection sites in the Lower Grand River hydrologic unit, Missouri and lowa, 2010 through 2018. 


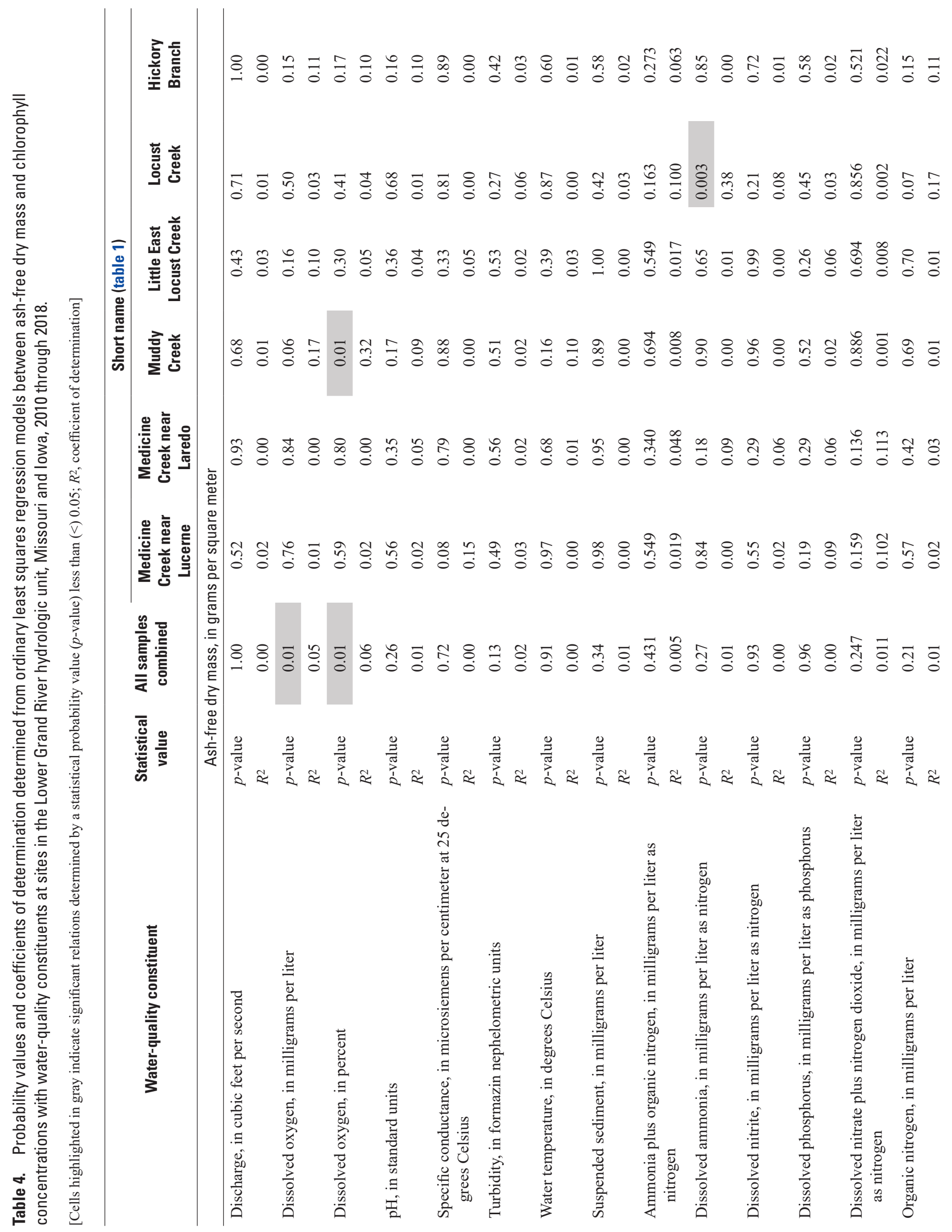




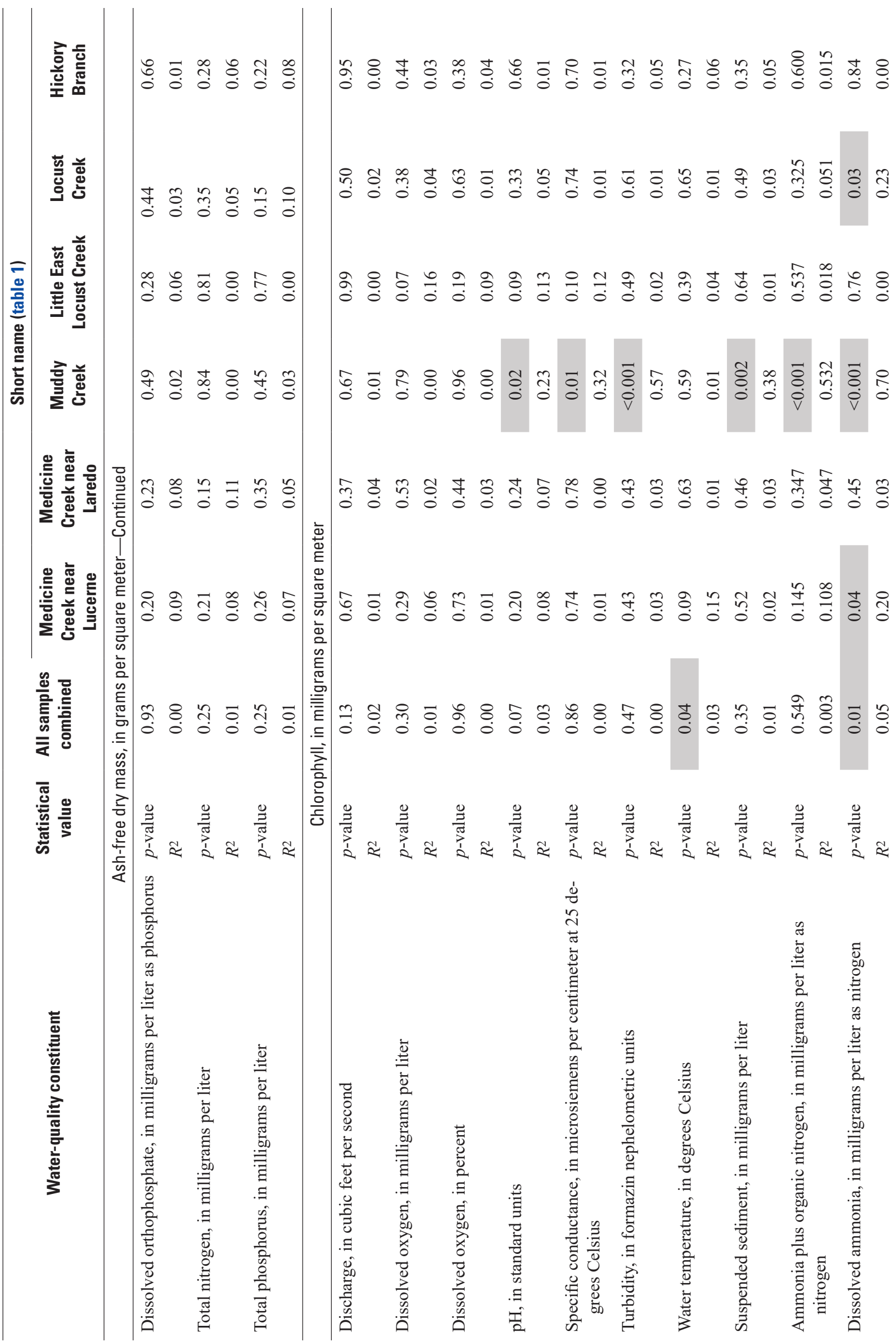




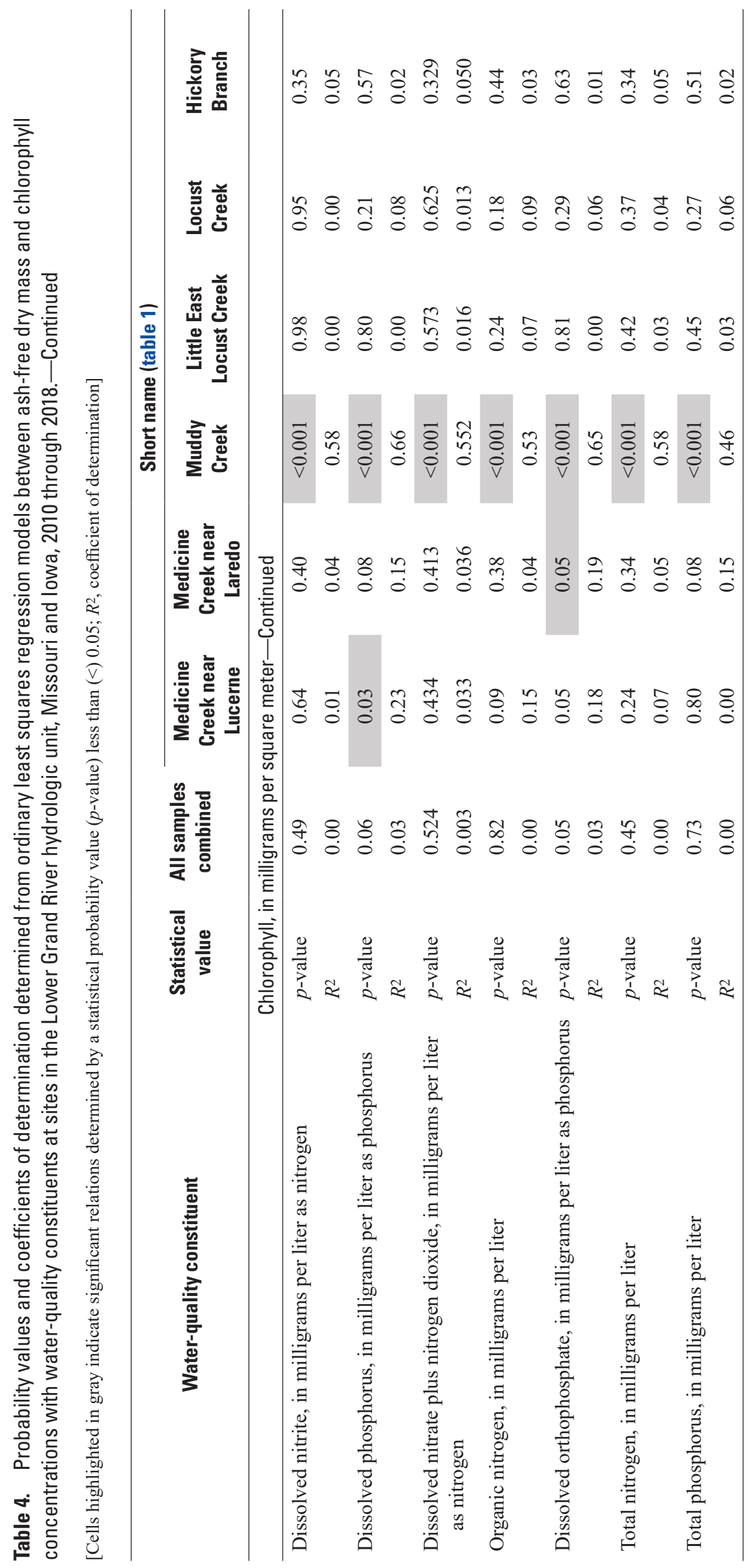


periphyton biomass may be complex, including more than one limiting factor, both physical and chemical factors, and are still not well understood at these sites.

Chlorophyll concentrations that exceed $100 \mathrm{mg} / \mathrm{m}^{2}$ have been described as nuisance algal conditions (Horner and others, 1983; Lohman and others, 1992; Rasmussen and others, 2009; Welch and others, 1988), which can lead to low dissolved-oxygen concentrations that kill fish and other aquatic life; can reduce recreational opportunities such as boating, swimming, and fishing; and can increase costs for irrigation and drinking-water treatment. Nuisance algal conditions were determined at every site during September 2012 (fig. 4; Krempa, 2020). Hickory Branch had the greatest number of exceedances (seven samples), as well as one sample that was equal to $100 \mathrm{mg} / \mathrm{m}^{2}$. Other exceedances were during April 2016 at Medicine Creek at Lucerne and Little East Locust Creek (fig. 4; Krempa, 2020). Nuisance conditions were determined at all sites; and harmful algal blooms are not well understood, the conditions that cause them are not determined, and they can occur and move quickly, which means they may occur more frequently in the Lower Grand River than were sampled.

\section{Periphyton Community Composition}

Degraded communities are more susceptible to ecological changes than more diverse communities; often they are dominated by a small number of taxa that are tolerant to the degraded conditions, and taxa richness and evenness are reduced. In total, 441 periphyton taxa were identified in 45 samples collected at Lower Grand River sites during 2011 through 2018 (Krempa, 2020). Sample taxa richness (total number of taxa; table 5) ranged from 31 to 78 taxa (table 5), with an average of 51 taxa. The most common algal group was diatoms (Bacillariophyceae) with 329 taxa, followed by green algae (Charophyta and Chlorophyta) with 48 taxa; 36 taxa were identified as blue-green algae or Cyanobacteria; 10 taxa were cryptomonads (Chrysophyta and Cryptophyta); and 9 euglenoids (Euglenophycota), 4 yellow-green algae (Ochrophyta), 2 dinoflagellate (Pyrrophycophyta), 2 red algae (Rhodophyta), and 1 unknown algae class were determined (Krempa, 2020). Four ambiguous taxa (taxa identified to a taxonomic level higher than genus) were identified including unknown algal flagellate, unknown cryptophyte, unknown cyanophyte, and unknown dinoflagellate (Krempa, 2020). Unknown cyanophytes were identified in two samples at 63.05 and 14.50 percent. The other ambiguous categories were present in four samples at less than 2.5 percent (Krempa, 2020). Taxa were considered rare if they were present in only one or two samples or were less than 1 percent of any sample; 72 percent of the taxa were considered rare. Ambiguous and rare taxa were not deleted, and the lowest taxonomic level was used.
Characteristics of common and dominate taxa were used to describe water-quality conditions in the Lower Grand River. In total, 9 taxa were present in more than 50 percent of all samples collected during 2011 through 2018 at these sites (at least 22 samples; Krempa, 2020). The 6 most frequently occurring taxa were in more than 30 samples: Cyclotella meneghiniana, Navicula rostellata, Nitzschia amphibia, Nitzschia inconspicua, Nitzschia palea, Planothidium frequentissimum. These taxa are all diatoms associated with eutrophic or hypereutrophic conditions (TROPHIC $=5$ or 6 ) and are indicators of high total nitrogen (DIATASTN=1) and high total phosphorus conditions (DIATASTP=1), except for Planothidium frequentissimum, which has a wide range of tolerance to nutrient conditions (TROPHIC=7) and is only an indicator of high total nitrogen not total phosphorus (Porter, 2008). Diatoms were the dominant division (cells highlighted in gray; table 5) in 60 percent of samples including all samples during 2014 and 2016. Green algae were dominant in 29 percent of samples including all but one sample in 2013. Blue-green algae, which is generally considered nuisance because of its ability to produce toxins, were dominant in two samples at Little East Locust Creek (2011 and 2018), and red algae were dominant in 2011 at Medicine Creek near Laredo and 2012 at Muddy Creek. Cryptomonads were dominant in one sample at Muddy Creek in 2018 (table 5; cell highlighted in gray).

When environments are degraded, communities are often dominated by a few taxa that are tolerant to the degraded environment conditions, and dominant taxa represent a larger abundance of the total biovolume. A diverse community is more robust. The top five most dominant taxa (numbered 1 through 5 in table 6) were determined by relative percentages of the total biovolume. The relative biovolume of dominant taxa 1 ranged from 9 to 99 percent. In 2011, four samples had dominant taxa 1 abundances that were at least 50 percent of the total (table 6). During 2012 and 2013, all samples except Locust Creek in 2012 had dominant taxa 1 that represented more than 50 percent of the total. During 2014, 2016, and 2017 , the only sample that had dominant taxa 1 abundances greater than 50 percent of the total was at Little East Locust Creek in 2017. In 2018, two samples had dominant taxa 1 abundances that were at least 50 percent of the total (table 6). During 2011 through 2013, the sums of the top five dominant taxa were greater than 90 percent in 58 percent of the samples, and no samples during 2014 through 2018 had sums of the top five dominant taxa greater than 90 percent (table 6). More samples during 2011 through 2013 than during 2014 through 2018 had dominant taxa 1 abundances that were at least 50 percent of the total sample and more samples with the sums of the top five dominant taxa greater than 90 percent. The relative abundances of dominant taxa 1 and the sums of the top five dominant taxa may indicate an increase in community diversity, evenness, and overall ecological health. 


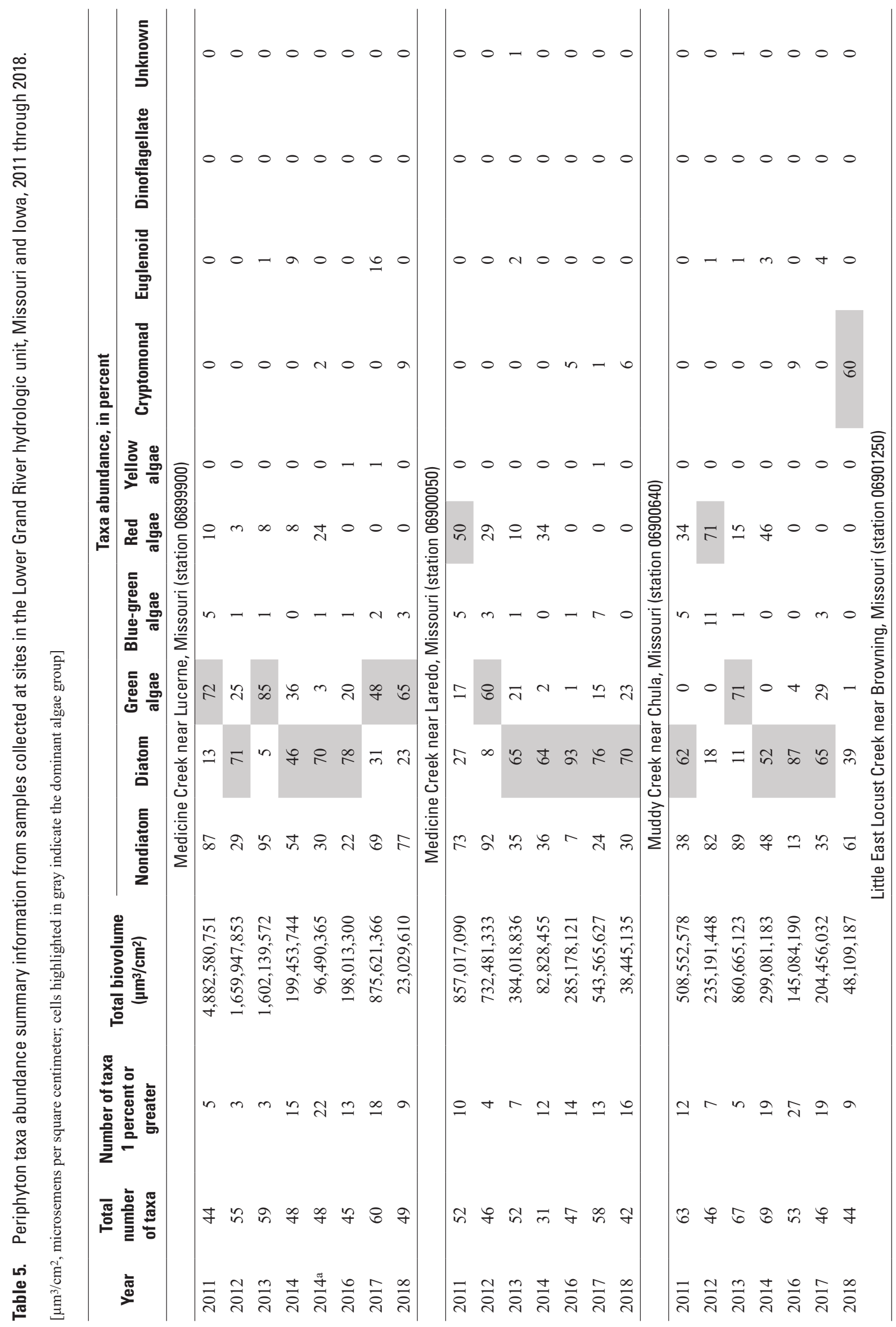




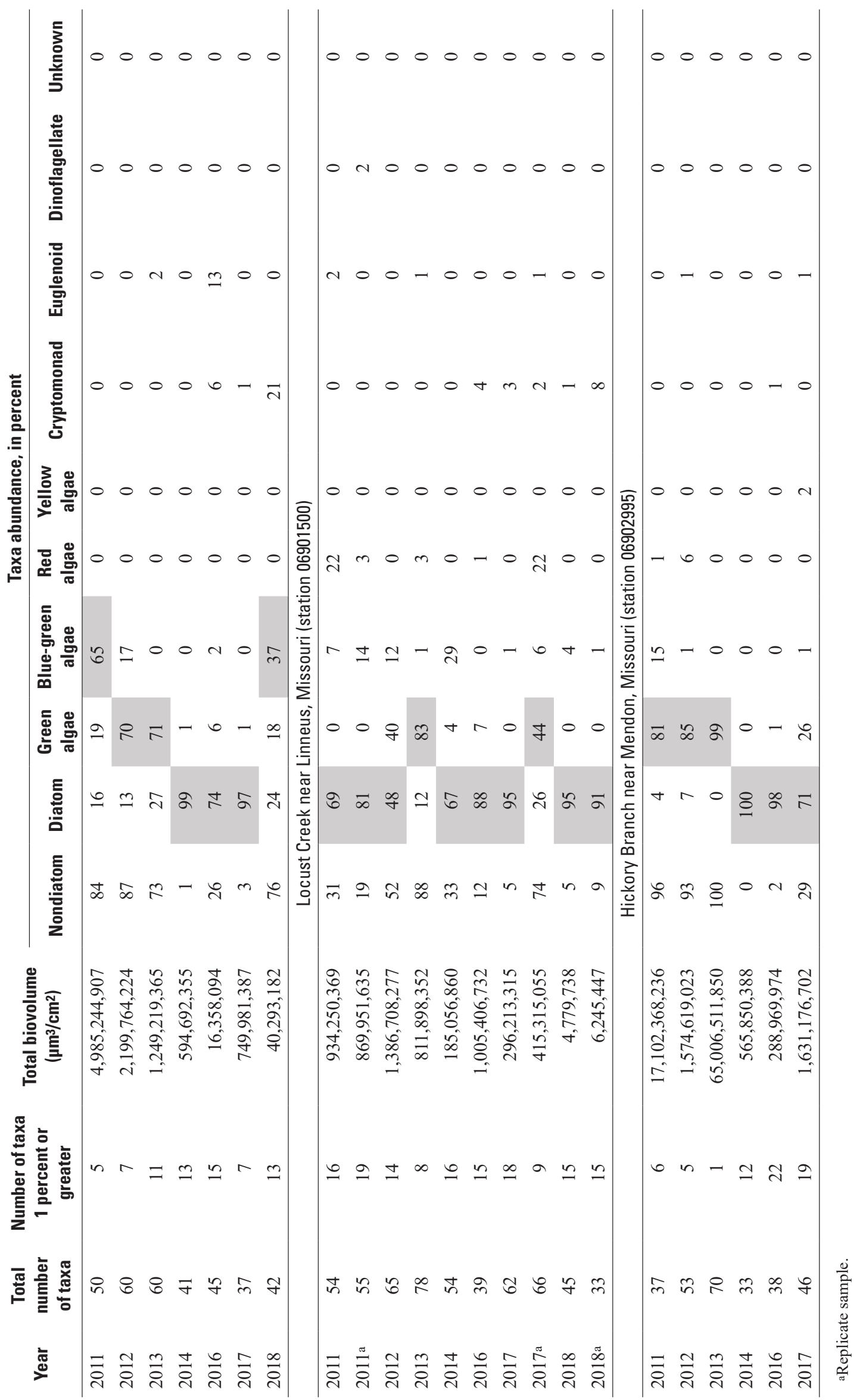




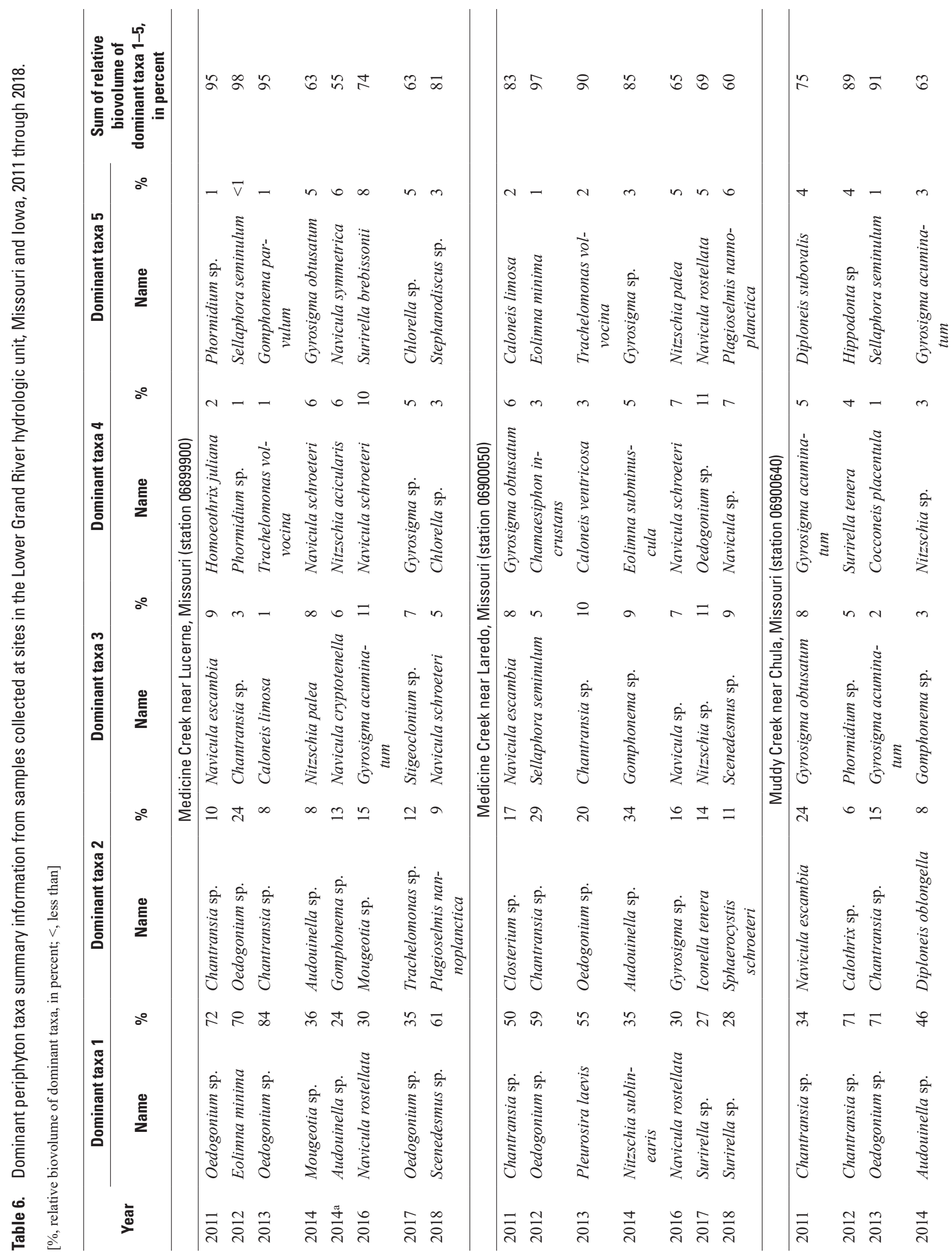




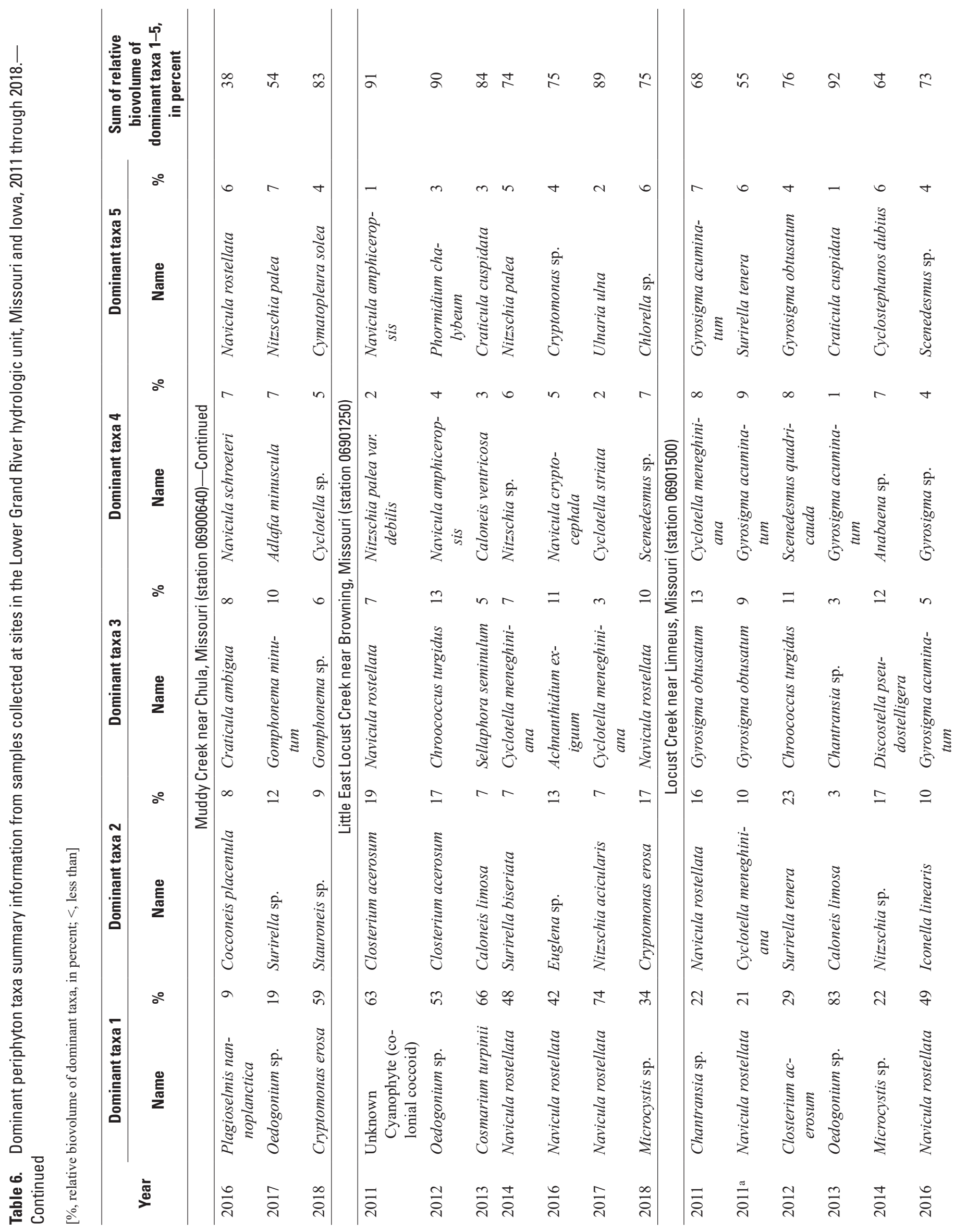




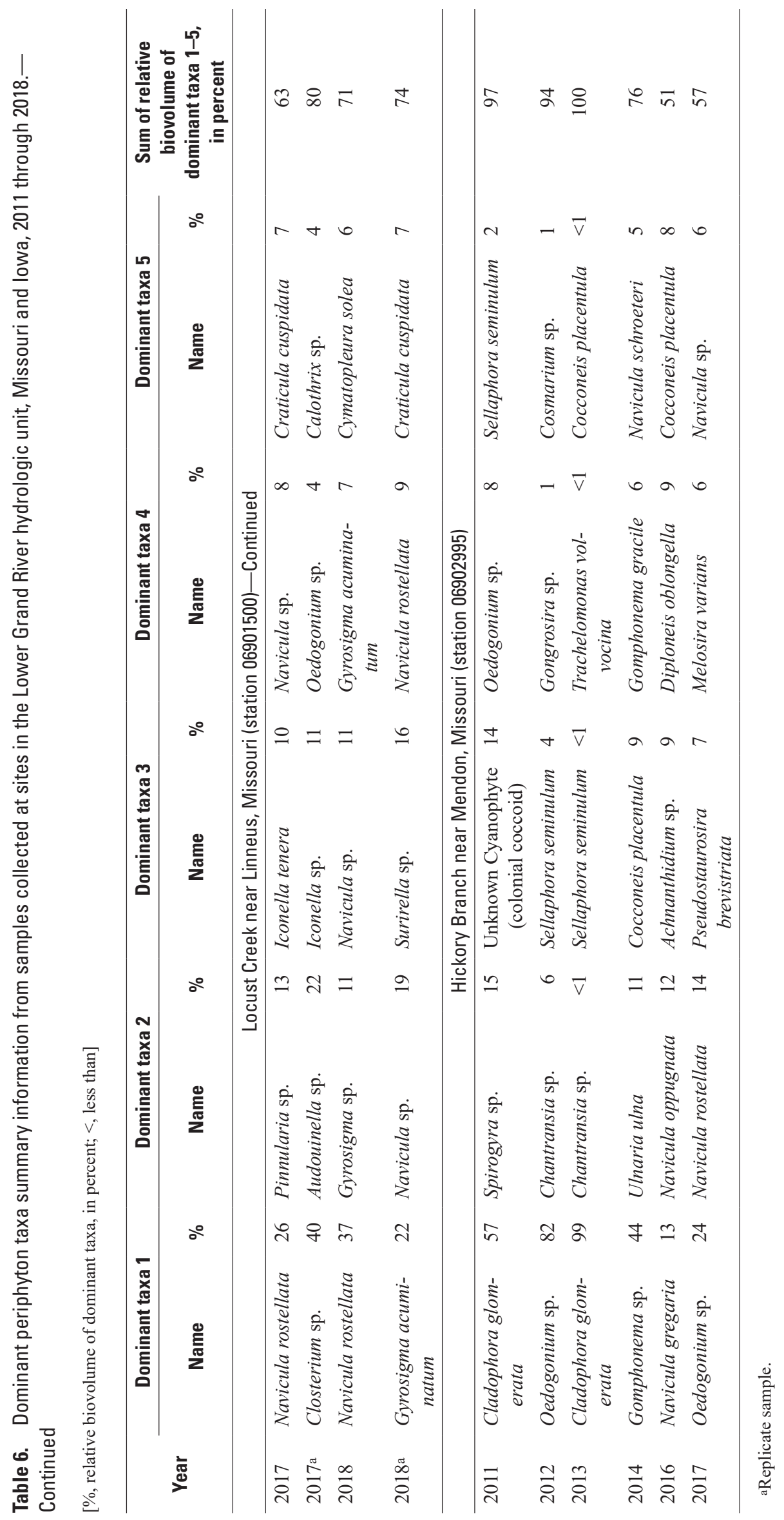


Dominant taxa relative abundances may indicate an increase in community diversity, evenness, and overall ecological health between years 2011 through 2013 and 2014 through 2018; however, it is important to note that the observed changes occurred with the change in identifying laboratories. Samples collected during 2010 through 2013 were identified by the Philadelphia Academy of Natural Sciences, and samples collected during 2014 through 2018 were identified at BSA Environmental Services. Inter-laboratory variability can occur because of many factors including different methods for calculating biomass, size classes, and counting units; different species identifications; varying levels of taxonomic detail; and the use of outdated names (Kann and others, 2015). Although attempts were made to standardize laboratory procedures and resolve taxonomic name differences, there is still potential for inter-laboratory variability that could skew results. The intent of MRBI is to reduce nutrient and sediment export to surface waters, which will improve water quality and likely improve community diversity, evenness, and overall ecological health. The agricultural conservation practices that were implemented were gradual and widespread, with no other observable changes within the watershed, which generally results in gradual ecological changes and rarely results in single year ecological shifts. The relative abundances of dominant taxa provide evidence supporting a more diverse and even periphyton community structure; however, inter-laboratory variability may have impacted and skewed this result.

\section{Water-Quality Effects on Periphyton Community Similarities}

Sample similarities were determined using a two-dimensional MDS plot with taxa biovolumes (micrometer per square centimeter) from community samples. Samples with similar taxa biovolumes plot near each other and more dissimilar samples are farther apart. The MDS plot was visually compared to site information and water-quality sample concentrations by changing the symbology of the plot to display factors that may affect sample similarities including site, year, month, and tertials of total nitrogen, total phosphorus, suspended sediment, chlorophyll, and AFDM concentrations. Changing the symbology of the plot does not affect distances among sample points but allows for a visual comparison between sample community and sample factor similarities. Factors that group like the sample community structure likely impact sample taxa similarities. The site factor that displayed grouping most like community structure was year (fig. 3). There was much overlap among years 2011 through 2013 and 2014 through 2017. Samples from 2018 plotted farther from other samples but were more like 2014 through 2017 samples than 2011 through 2013 samples. The 2016 sample from Little East Locust Creek was more like samples from 2018 than other samples from 2016. Hickory Branch samples for 2011, 2013, 2014, and 2017 plotted farther from other samples collected at other sites during the same year, indicating sample taxa biovolumes from Hickory Branch were generally less like other sites. The sample biovolume MDS plot shows that samples collected during 2011 through 2013 are more similar than samples collected during 2014 through 2018.

Like dominant taxa relative abundances, there is a difference between community taxa biodiversity data collected during 2011 through 2013 and data collected during 2014 through 2018, which could indicate a shift in periphyton community structure. Again, it is important to note that the observed changes occurred with the change in identifying laboratories, and inter-laboratory variability can occur because of many factors (Kann and others, 2015). The agricultural conservation practices that were implemented were gradual and widespread, with no other observable changes within the watershed, which generally results in gradual ecological changes and rarely results in single year ecological shifts. The MDS plot and relative abundances of dominant taxa provide evidence supporting a change in the periphyton community structure; however, because this change occurred with the change in identifying laboratories, inter-laboratory variability cannot be overlooked as a source of the variability in data.

The indication that inter-laboratory variability may have a large effect on results from periphyton community identification and enumeration data poses a problem in the interpretation of periphyton data when different identifying laboratories are used. Direct comparisons of taxa identified by different laboratories may result in substantiable differences because of different procedures and expertise of the identifying laboratory, which could skew or mask the effects of environmental factors on periphyton communities, making it difficult to accurately assess ecological health. However, community attributes that describe taxa traits and taxa tolerances likely could still describe ecological conditions that affect the periphyton communities because community traits are used to assess the communities and specific taxonomic identifications are not compared directly.

\section{Periphyton Community Attributes and Taxa Metrics}

The characteristics of the periphyton community can describe the water-quality condition and ecological health. Periphyton community attributes include tolerances and optimum ranges for a variety of water-quality conditions, and regional and national community attributes were calculated from taxa metrics using relative biovolumes of taxa identified in community samples. Further discussion on community attributes, taxa metrics, and metric classes was provided in Porter (2008). 
In streams with low dissolved nitrogen, large populations of nitrogen-fixing algae can form because they can use atmospheric nitrogen and do not rely completely on dissolved nitrogen (Porter, 2008). The "NF" attribute describes taxa that are nitrogen fixing (metric class 1) and are not nitrogen fixing (metric class 2; tables 7, 8; Porter, 2008). At least 82 percent of each sample was not nitrogen fixing, and the maximum and average relative abundance of nitrogen-fixing algae was 7 and 1 percent, respectively (table 7). Not nitrogen-fixing algae were more abundant than nitrogen-fixing algae, and nitrogen-fixing algae abundances were consistently low. This indicates dissolved-nitrogen concentrations are likely not low enough to affect periphyton community structure.

High nutrient concentrations and subsequent water-quality problems, including excessive plant and algae growth, low light availability, and low dissolved-oxygen concentrations, can affect periphyton communities; and their abilities to tolerate or thrive in different nutrient concentrations are known for many taxa. The "TROPHIC" attribute (tables 7, 8) classifies diatom nutrient tolerances into seven metric classes ranging from low (oligotrophic; metric class 1) to extremely rich nutrient concentrations (hypereutraphentic; metric class 6), includes two intermediate classes, mesotrophic (metric class 3) and mesotrophic-eutrophic (metric class 4), and has one class that includes diatoms that are indifferent or have a wide range of tolerance to nutrients (euytraphentic; metric class 7). Eutrophic diatoms (metric class 5) are associated with high nutrient environments, were present in every sample, and had the greatest average relative abundance (51 percent) of all TROPHIC classes (table 7; Porter, 2008). Hypereutrophic diatoms (metric class 6) were identified in 80 percent of samples; however, relative abundances were generally low. The greatest relative abundance was 18 percent, with an average relative abundance of 3 percent (tables 7 , 8). Taxa associated with low nutrient environments (metric classes 1 and 2) were present in no more than 36 percent of samples, and relative abundances were low. The greatest relative abundance was 12 percent, and average relative abundances were less than 1 percent (table 7). Diatoms associated with high nutrient environments were identified in all samples and at greater abundances than those associated with low nutrient environments, indicating high nutrient conditions are likely affecting the diatom community structure.

Soft algae taxa that are tolerant to or require high nutrient concentrations were described in the "EUTROPHIC SOFT" attribute as eutrophic soft algae (metric class 1; tables 7, 8; Porter, 2008). Taxa that are not classified in metric class 1 (NA) are not tolerant to high nutrient concentrations or do not have available nutrient tolerance information. Eutrophic soft algae were identified in most samples ( 84 percent) and represented up to 100 percent of the sample. Eutrophic soft algae taxa abundances were greatest during 2018, except at Locust Creek where abundances were greater in 2014 and at Hickory Branch, which was not sampled in 2018 because there was no streamflow (table 8). Average relative abundance was greater for taxa not identified as eutrophic (table 7); however, this represents taxa that are sensitive to high nutrients, are indifferent to nutrients, and have unknown nutrient tolerances. Soft algae that are tolerant to or require high nutrient concentrations were identified in most samples and often in high abundances, indicating high nutrient conditions are likely affecting the soft algae community structure.

The "EUTROPHIC" attribute (Porter, 2008) includes diatoms and soft algae, and eutrophic taxa are classified in metric class 1. Eutrophic algae were identified in every sample, and relative abundances ranged from 3 to 100 percent, with an average relative abundance of 43 percent (tables 7,8 ). Average relative abundance was greater for taxa not described as eutrophic (NA); however, the average relative abundances were similar between eutrophic taxa and taxa not described as eutrophic, and undescribed taxa represents taxa sensitive to high nutrients, indifferent to nutrients, and that have unknown nutrient tolerances. Diatoms that are associated with high nutrient environments were identified in all samples and in greater abundances than those associated with low nutrient environments. Soft algae that are tolerant to or require high nutrient concentrations were identified in most samples and often in high abundances. Eutrophic algae, which includes diatoms and soft algae, had an average relative abundance similar to undescribed taxa. This information indicates high nutrient conditions likely are common and are affecting the overall periphyton community structure.

The previous tolerance attributes (NF, TROPHIC, EUTROPHIC SOFT, and EUTROPHIC) describe tolerance to all nutrients, which includes nitrogen and phosphorus, but tolerances can also be identified specifically for total nitrogen and total phosphorus. National total nitrogen and total phosphorus attributes were described for diatoms and soft algae, and regional metrics were described for diatoms. The central and western plains regional attributes were used for the Lower Grand River.

The "DIATASTN" attribute describes diatoms as indicating high (metric class 1 ) or low (metric class 2) total nitrogen (tables 7, 9; Porter, 2008). Diatoms indicating high total nitrogen were identified in all samples, and relative abundances ranged from 5 to 99 percent, with an average relative abundance of 40 percent. Diatoms indicating low total nitrogen were identified in only 20 percent of samples, and the greatest and average relative abundances were 11 and 1 percent, respectively. Only one sample had a greater abundance of diatoms indicating low total nitrogen rather than high total nitrogen (Hickory Branch during 2014), and abundances of diatoms indicating low total nitrogen (11percent) and diatoms indicating high total nitrogen (9 percent) were similar (table 9). Diatoms indicating high total nitrogen conditions were present in all samples and at greater abundances than low total nitrogen diatoms, which indicates that high total nitrogen conditions likely are common and are affecting the diatom community structure. 
Table 7. Periphyton attribute statistical summary information of metric classes for periphyton samples collected in the Lower Grand River hydrologic unit, Missouri and lowa, 2011 through 2018.

[NA, not applicable]

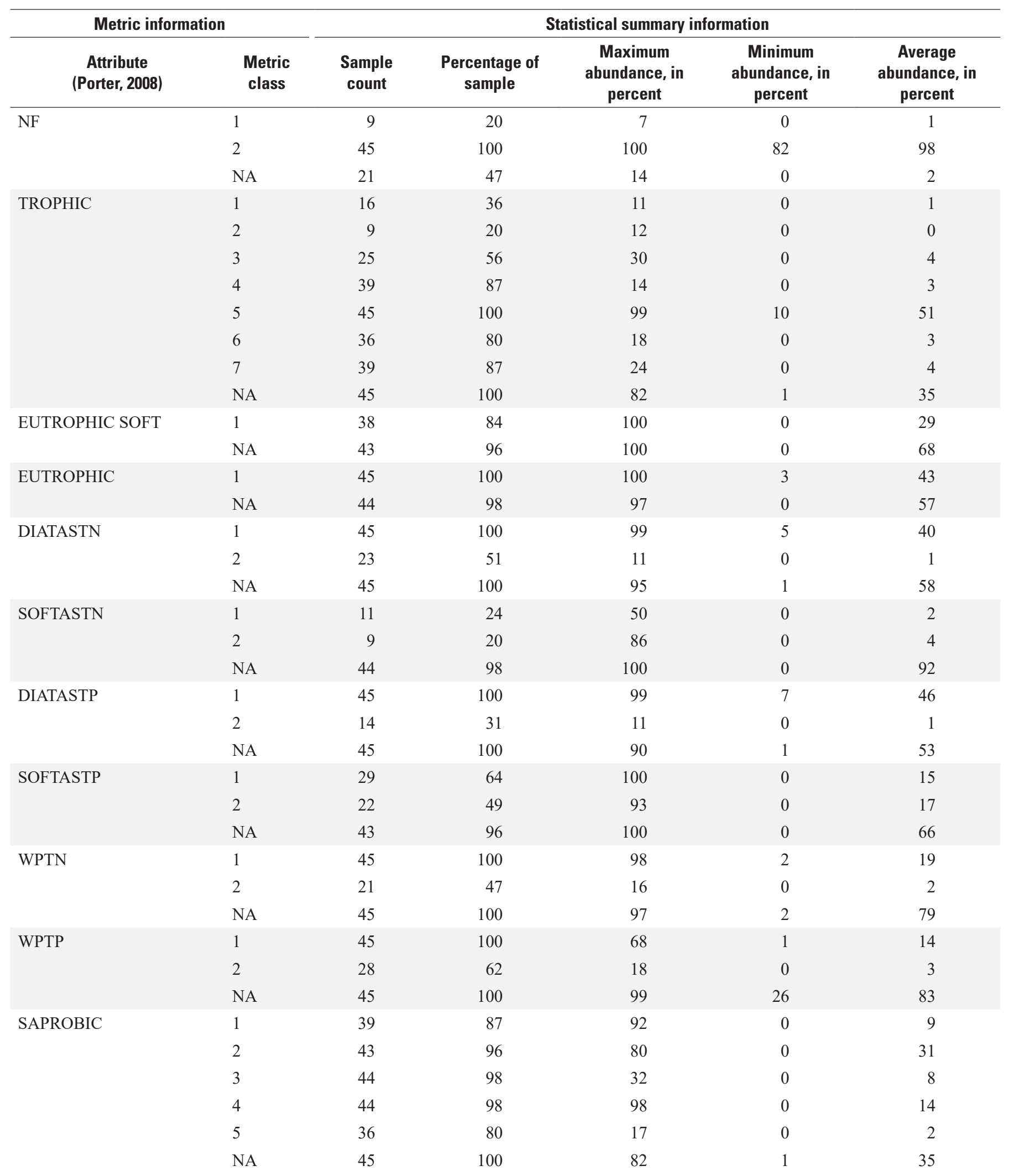


Table 7. Periphyton attribute statistical summary information of metric classes for periphyton samples collected in the Lower Grand River hydrologic unit, Missouri and lowa, 2011 through 2018.—Continued

[NA, not applicable]

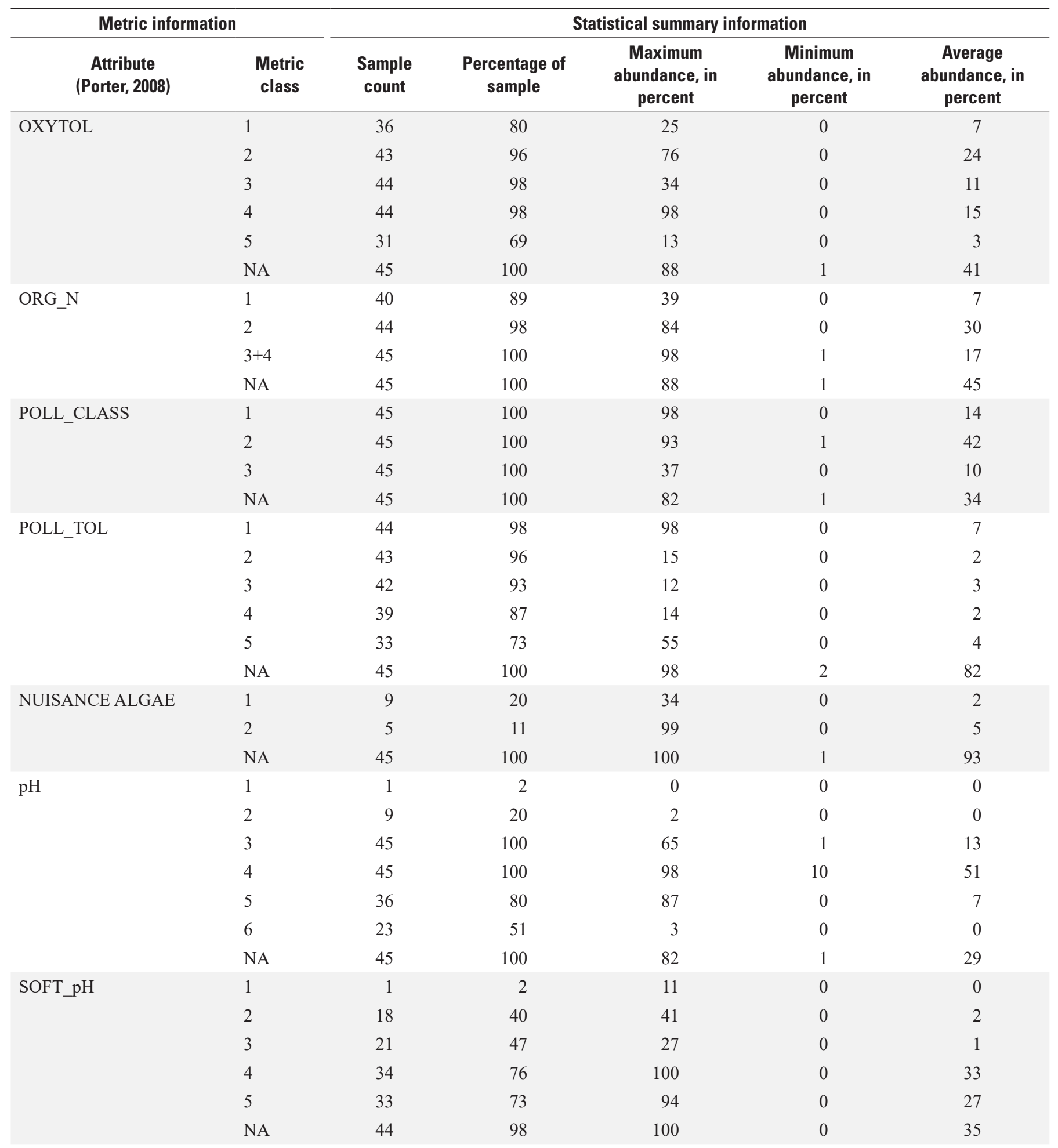


Table 7. Periphyton attribute statistical summary information of metric classes for periphyton samples collected in the Lower Grand River hydrologic unit, Missouri and lowa, 2011 through 2018.-Continued

[NA, not applicable]

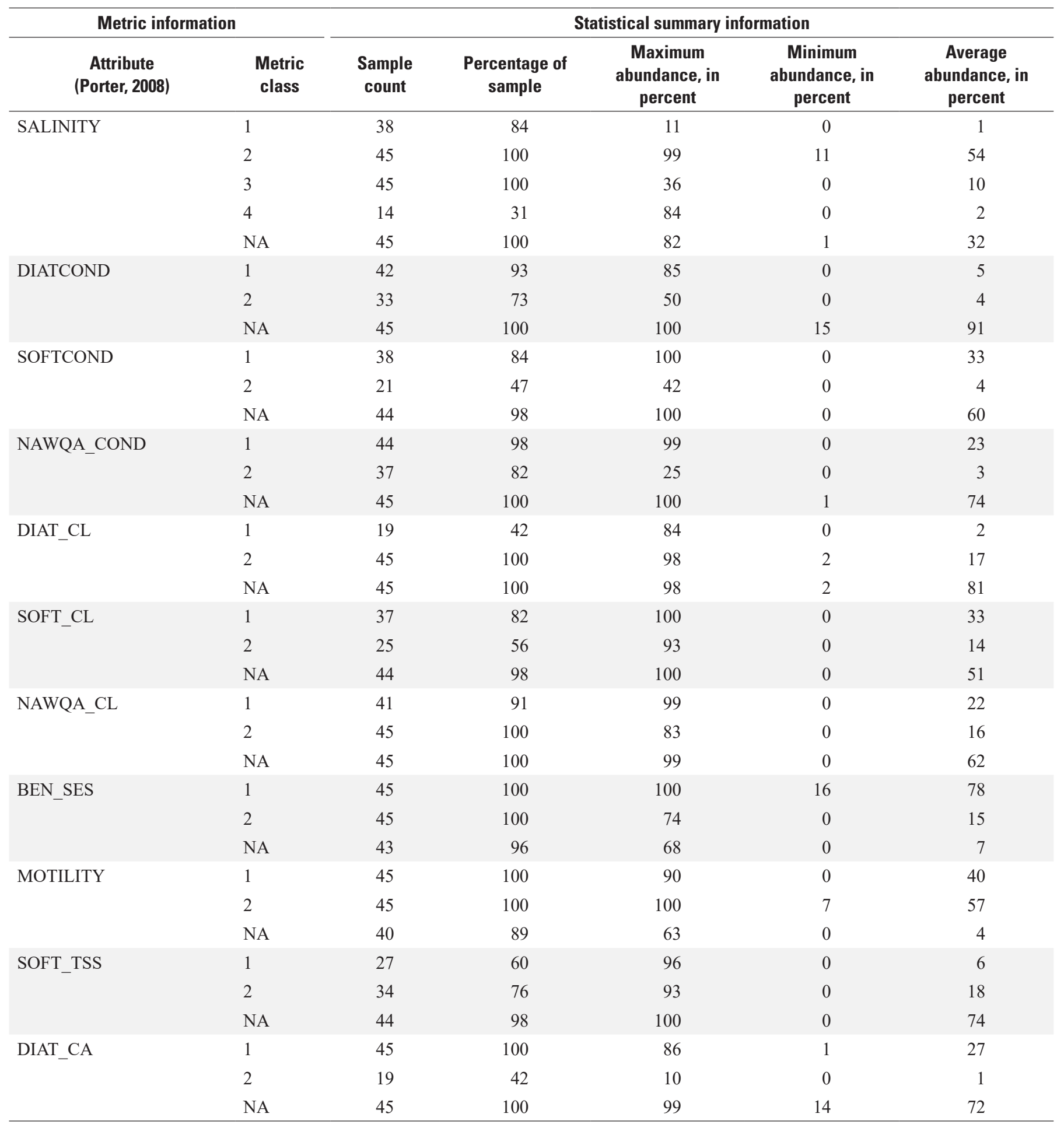


Table 8. Relative abundance of national attributes describing nutrient concentrations (Porter, 2008) by metric class for periphyton samples collected in the Lower Grand River hydrologic unit, Missouri and lowa, 2011 through 2018.

\begin{tabular}{|c|c|c|c|c|c|c|c|c|c|c|c|c|c|c|c|}
\hline \multirow{3}{*}{ Year } & \multicolumn{15}{|c|}{ Attribute (Porter, 2008) relative abundance by metric class, in percent } \\
\hline & \multicolumn{3}{|c|}{ NF } & \multicolumn{8}{|c|}{ TROPHIC } & \multicolumn{2}{|c|}{ EUTROPHIC SOFT } & \multicolumn{2}{|c|}{ EUTROPHIC } \\
\hline & 1 & 2 & NA & 1 & 2 & 3 & 4 & 5 & 6 & 7 & NA & 1 & NA & 1 & NA \\
\hline \multicolumn{16}{|c|}{ Medicine Creek near Lucerne, Missouri } \\
\hline 2011 & 0 & 100 & 0 & 0 & 0 & 4 & 2 & 17 & 1 & 0 & 76 & 0 & 100 & 3 & 97 \\
\hline 2012 & 0 & 100 & 0 & 0 & 0 & 0 & 0 & 99 & 0 & 0 & 1 & 0 & 100 & 71 & 29 \\
\hline 2013 & 0 & 100 & 0 & 2 & 1 & 20 & 5 & 48 & 0 & 2 & 21 & 1 & 99 & 3 & 97 \\
\hline 2014 & 0 & 99 & 1 & 0 & 2 & 0 & 3 & 45 & 18 & 3 & 30 & 1 & 99 & 31 & 69 \\
\hline 2014a & 0 & 100 & 0 & 0 & 1 & 0 & 6 & 25 & 5 & 12 & 50 & 10 & 90 & 28 & 72 \\
\hline 2016 & 0 & 99 & 1 & 0 & 0 & 0 & 2 & 74 & 4 & 2 & 18 & 26 & 74 & 68 & 32 \\
\hline 2017 & 0 & 99 & 1 & 3 & 0 & 0 & 2 & 51 & 2 & 2 & 40 & 27 & 73 & 35 & 65 \\
\hline 2018 & 1 & 90 & 9 & 4 & 0 & 1 & 1 & 39 & 2 & 0 & 53 & 85 & 15 & 75 & 25 \\
\hline \multicolumn{16}{|c|}{ Medicine Creek near Laredo, Missouri } \\
\hline 2011 & 0 & 100 & 0 & 1 & 0 & 9 & 7 & 48 & 2 & 3 & 31 & 1 & 99 & 16 & 84 \\
\hline 2012 & 0 & 100 & 0 & 0 & 0 & 0 & 5 & 85 & 1 & 1 & 7 & 0 & 100 & 7 & 93 \\
\hline 2013 & 0 & 100 & 0 & 0 & 0 & 3 & 5 & 89 & 0 & 0 & 3 & 2 & 98 & 62 & 38 \\
\hline 2014 & 0 & 98 & 2 & 0 & 0 & 0 & 0 & 15 & 4 & 4 & 78 & 6 & 94 & 14 & 86 \\
\hline 2016 & 0 & 99 & 1 & 0 & 0 & 0 & 5 & 49 & 6 & 1 & 39 & 20 & 80 & 57 & 43 \\
\hline 2017 & 3 & 96 & 1 & 1 & 0 & 0 & 1 & 31 & 2 & 6 & 59 & 18 & 82 & 30 & 70 \\
\hline 2018 & 0 & 93 & 7 & 0 & 0 & 1 & 7 & 18 & 0 & 10 & 63 & 74 & 26 & 40 & 60 \\
\hline \multicolumn{16}{|c|}{ Muddy Creek near Chula, Missouri } \\
\hline 2011 & 1 & 99 & 0 & 1 & 0 & 6 & 2 & 32 & 1 & 1 & 58 & 1 & 99 & 22 & 78 \\
\hline 2012 & 6 & 90 & 4 & 0 & 0 & 3 & 2 & 65 & 0 & 2 & 27 & 0 & 100 & 12 & 88 \\
\hline 2013 & 0 & 100 & 0 & 0 & 0 & 6 & 9 & 44 & 0 & 4 & 38 & 1 & 99 & 6 & 94 \\
\hline 2014 & 0 & 99 & 1 & 0 & 0 & 3 & 6 & 25 & 2 & 8 & 55 & 0 & 100 & 17 & 83 \\
\hline 2016 & 0 & 87 & 13 & 1 & 0 & 0 & 5 & 35 & 2 & 11 & 46 & 30 & 70 & 41 & 59 \\
\hline 2017 & 0 & 100 & 0 & 11 & 0 & 1 & 1 & 30 & 11 & 2 & 44 & 29 & 71 & 37 & 63 \\
\hline 2018 & 0 & 99 & 1 & 1 & 0 & 0 & 5 & 10 & 1 & 1 & 82 & 98 & 2 & 66 & 34 \\
\hline \multicolumn{16}{|c|}{ Little East Locust Creek near Browning, Missouri } \\
\hline 2011 & 1 & 99 & 0 & 10 & 0 & 0 & 7 & 58 & 5 & 2 & 18 & 24 & 76 & 31 & 69 \\
\hline 2012 & 0 & 100 & 0 & 1 & 0 & 2 & 3 & 49 & 3 & 4 & 37 & 35 & 65 & 38 & 62 \\
\hline 2013 & 0 & 100 & 0 & 0 & 0 & 27 & 14 & 43 & 1 & 1 & 14 & 1 & 99 & 16 & 84 \\
\hline 2014 & 1 & 98 & 1 & 0 & 0 & 3 & 4 & 70 & 5 & 2 & 16 & 82 & 18 & 79 & 21 \\
\hline 2016 & 0 & 99 & 1 & 0 & 0 & 0 & 3 & 63 & 2 & 24 & 7 & 73 & 27 & 70 & 30 \\
\hline 2017 & 0 & 100 & 0 & 0 & 0 & 0 & 1 & 88 & 1 & 3 & 8 & 40 & 60 & 88 & 12 \\
\hline 2018 & 0 & 96 & 4 & 3 & 0 & 0 & 2 & 47 & 2 & 11 & 35 & 90 & 10 & 81 & 19 \\
\hline \multicolumn{16}{|c|}{ Locust Creek near Linneus, Missouri } \\
\hline 2011 & 3 & 97 & 0 & 2 & 0 & 9 & 1 & 65 & 3 & 1 & 20 & 16 & 84 & 52 & 48 \\
\hline $2011^{\mathrm{a}}$ & 0 & 100 & 0 & 1 & 0 & 2 & 6 & 74 & 1 & 2 & 14 & 0 & 100 & 65 & 35 \\
\hline 2012 & 0 & 100 & 0 & 1 & 1 & 4 & 4 & 76 & 5 & 9 & 2 & 98 & 2 & 91 & 9 \\
\hline 2013 & 0 & 100 & 0 & 0 & 2 & 30 & 9 & 43 & 1 & 1 & 15 & 1 & 99 & 7 & 93 \\
\hline 2014 & 7 & 93 & 0 & 0 & 0 & 0 & 0 & 48 & 9 & 3 & 40 & 98 & 2 & 70 & 30 \\
\hline 2016 & 0 & 100 & 0 & 0 & 12 & 0 & 4 & 67 & 2 & 0 & 15 & 88 & 12 & 74 & 26 \\
\hline 2017 & 0 & 93 & 7 & 0 & 0 & 1 & 3 & 49 & 0 & 1 & 46 & 3 & 97 & 50 & 50 \\
\hline
\end{tabular}


Table 8. Relative abundance of national attributes describing nutrient concentrations (Porter, 2008) by metric class for periphyton samples collected in the Lower Grand River hydrologic unit, Missouri and lowa, 2011 through 2018. - Continued

\begin{tabular}{|c|c|c|c|c|c|c|c|c|c|c|c|c|c|c|c|}
\hline \multirow{3}{*}{ Year } & \multicolumn{15}{|c|}{ Attribute (Porter, 2008) relative abundance by metric class, in percent } \\
\hline & \multicolumn{3}{|c|}{ NF } & \multicolumn{8}{|c|}{ TROPHIC } & \multicolumn{2}{|c|}{ EUTROPHIC SOFT } & \multicolumn{2}{|c|}{ EUTROPHIC } \\
\hline & 1 & 2 & NA & 1 & 2 & 3 & 4 & 5 & 6 & 7 & NA & 1 & NA & 1 & NA \\
\hline \multicolumn{16}{|c|}{ Locust Creek near Linneus, Missouri-Continued } \\
\hline $2017 \mathrm{a}$ & 4 & 82 & 14 & 0 & 0 & 3 & 1 & 24 & 3 & 1 & 69 & 1 & 99 & 8 & 92 \\
\hline 2018 & 0 & 99 & 1 & 0 & 0 & 0 & 3 & 59 & 2 & 1 & 36 & 23 & 77 & 61 & 39 \\
\hline $2018^{a}$ & 0 & 98 & 2 & 0 & 0 & 0 & 1 & 50 & 1 & 2 & 45 & 1 & 99 & 48 & 52 \\
\hline \multicolumn{16}{|c|}{ Hickory Branch near Mendon, Missouri } \\
\hline 2011 & 0 & 100 & 0 & 0 & 0 & 1 & 2 & 80 & 0 & 0 & 17 & 75 & 25 & 75 & 25 \\
\hline 2012 & 0 & 100 & 0 & 0 & 1 & 8 & 0 & 87 & 1 & 1 & 2 & 1 & 99 & 7 & 93 \\
\hline 2013 & 0 & 100 & 0 & 0 & 0 & 0 & 5 & 69 & 1 & 4 & 21 & 100 & 0 & 100 & 0 \\
\hline 2014 & 0 & 100 & 0 & 0 & 1 & 6 & 0 & 29 & 1 & 12 & 51 & 0 & 0 & 29 & 71 \\
\hline 2016 & 0 & 98 & 2 & 1 & 0 & 1 & 0 & 33 & 2 & 4 & 60 & 33 & 67 & 35 & 65 \\
\hline 2017 & 0 & 97 & 3 & 0 & 1 & 6 & 1 & 34 & 0 & 13 & 46 & 10 & 90 & 28 & 72 \\
\hline
\end{tabular}

aReplicate sample.

Table 9. Relative abundance of national and regional attributes describing total nitrogen or total phosphorus concentrations (Porter, 2008) by metric class for periphyton samples collected in the Lower Grand River hydrologic unit, Missouri and lowa, 2011 through 2018.

\begin{tabular}{|c|c|c|c|c|c|c|c|c|c|c|c|c|c|c|c|c|c|c|}
\hline \multirow{3}{*}{ Year } & \multicolumn{18}{|c|}{ Attribute (Porter, 2008) relative abundance by metric class, in percent } \\
\hline & \multicolumn{3}{|c|}{ DIATASTN } & \multicolumn{3}{|c|}{ SOFTASTN } & \multicolumn{3}{|c|}{ DIATASTP } & \multicolumn{3}{|c|}{ SOFTASTP } & \multicolumn{3}{|c|}{ WPTN } & \multicolumn{3}{|c|}{ WPTP } \\
\hline & 1 & 2 & NA & 1 & 2 & NA & 1 & 2 & NA & 1 & 2 & NA & 1 & 2 & NA & 1 & 2 & NA \\
\hline \multicolumn{19}{|c|}{ Medicine Creek near Lucerne, Missouri } \\
\hline 2011 & 18 & 0 & 82 & 0 & 0 & 100 & 18 & 0 & 82 & 0 & 15 & 85 & 8 & 0 & 92 & 3 & 0 & 97 \\
\hline 2012 & 99 & 0 & 1 & 0 & 0 & 99 & 99 & 0 & 1 & 0 & 11 & 88 & 98 & 0 & 2 & 1 & 0 & 99 \\
\hline 2013 & 45 & 1 & 54 & 0 & 0 & 100 & 48 & 1 & 51 & 0 & 9 & 90 & 11 & 0 & 88 & 15 & 1 & 83 \\
\hline 2014 & 48 & 1 & 50 & 1 & 0 & 99 & 40 & 1 & 58 & 1 & 67 & 33 & 34 & 0 & 66 & 28 & 1 & 71 \\
\hline 2014a & 42 & 3 & 55 & 9 & 0 & 91 & 35 & 3 & 61 & 9 & 0 & 91 & 26 & 3 & 71 & 15 & 3 & 82 \\
\hline 2016 & 60 & 0 & 40 & 0 & 0 & 100 & 73 & 0 & 26 & 21 & 68 & 11 & 18 & 0 & 82 & 20 & 0 & 80 \\
\hline 2017 & 28 & 0 & 72 & 7 & 11 & 83 & 47 & 0 & 53 & 7 & 11 & 83 & 3 & 1 & 96 & 10 & 1 & 89 \\
\hline 2018 & 12 & 0 & 87 & 0 & 0 & 100 & 13 & 0 & 87 & 1 & 0 & 99 & 3 & 0 & 97 & 5 & 0 & 94 \\
\hline \multicolumn{19}{|c|}{ Medicine Creek near Laredo, Missouri } \\
\hline 2011 & 26 & 0 & 74 & 1 & 0 & 99 & 52 & 0 & 48 & 1 & 72 & 27 & 35 & 0 & 65 & 15 & 0 & 85 \\
\hline 2012 & 79 & 0 & 21 & 0 & 3 & 97 & 80 & 0 & 20 & 0 & 32 & 68 & 75 & 3 & 22 & 68 & 4 & 28 \\
\hline 2013 & 5 & 0 & 95 & 0 & 0 & 100 & 89 & 0 & 11 & 6 & 30 & 64 & 3 & 0 & 97 & 1 & 0 & 99 \\
\hline 2014 & 20 & 0 & 80 & 0 & 0 & 100 & 21 & 0 & 79 & 0 & 0 & 100 & 19 & 0 & 80 & 14 & 0 & 86 \\
\hline 2016 & 54 & 1 & 45 & 0 & 0 & 100 & 52 & 0 & 48 & 0 & 0 & 100 & 16 & 0 & 83 & 17 & 0 & 82 \\
\hline 2017 & 13 & 6 & 82 & 0 & 0 & 100 & 14 & 6 & 80 & 14 & 12 & 75 & 3 & 0 & 97 & 5 & 6 & 89 \\
\hline 2018 & 14 & 8 & 79 & 0 & 0 & 100 & 19 & 8 & 73 & 0 & 0 & 100 & 4 & 0 & 96 & 6 & 8 & 86 \\
\hline \multicolumn{19}{|c|}{ Muddy Creek near Chula, Missouri } \\
\hline 2011 & 11 & 0 & 89 & 0 & 1 & 99 & 29 & 0 & 71 & 0 & 90 & 10 & 19 & 0 & 81 & 3 & 0 & 97 \\
\hline 2012 & 24 & 1 & 75 & 0 & 0 & 100 & 38 & 0 & 62 & 0 & 93 & 7 & 29 & 1 & 70 & 13 & 1 & 87 \\
\hline 2013 & 24 & 1 & 75 & 0 & 0 & 100 & 26 & 1 & 74 & 1 & 17 & 81 & 21 & 2 & 78 & 10 & 2 & 89 \\
\hline 2014 & 15 & 1 & 84 & 0 & 0 & 100 & 15 & 0 & 85 & 0 & 0 & 100 & 9 & 16 & 75 & 7 & 16 & 78 \\
\hline
\end{tabular}


Table 9. Relative abundance of national and regional attributes describing total nitrogen or total phosphorus concentrations (Porter, 2008) by metric class for periphyton samples collected in the Lower Grand River hydrologic unit, Missouri and lowa, 2011 through 2018.-Continued

\begin{tabular}{|c|c|c|c|c|c|c|c|c|c|c|c|c|c|c|c|c|c|c|}
\hline \multirow{3}{*}{ Year } & \multicolumn{18}{|c|}{ Attribute (Porter, 2008) relative abundance by metric class, in percent } \\
\hline & \multicolumn{3}{|c|}{ DIATASTN } & \multicolumn{3}{|c|}{ SOFTASTN } & \multicolumn{3}{|c|}{ DIATASTP } & \multicolumn{3}{|c|}{ SOFTASTP } & \multicolumn{3}{|c|}{ WPTN } & \multicolumn{3}{|c|}{ WPTP } \\
\hline & 1 & 2 & NA & 1 & 2 & NA & 1 & 2 & NA & 1 & 2 & NA & 1 & 2 & NA & 1 & 2 & NA \\
\hline 2016 & 22 & 2 & 76 & 0 & 0 & 100 & 25 & 1 & 73 & 0 & 0 & 100 & 9 & 4 & 87 & 8 & 4 & 87 \\
\hline 2017 & 22 & 0 & 78 & 0 & 0 & 100 & 21 & 0 & 78 & 14 & 0 & 86 & 13 & 3 & 84 & 12 & 4 & 84 \\
\hline \multicolumn{19}{|c|}{ Little East Locust Creek near Browning, Missouri } \\
\hline 2011 & 74 & 2 & 24 & 1 & 1 & 99 & 74 & 0 & 26 & 1 & 22 & 77 & 21 & 3 & 76 & 23 & 1 & 76 \\
\hline 2012 & 50 & 1 & 50 & 0 & 0 & 100 & 54 & 0 & 46 & 0 & 20 & 80 & 25 & 1 & 74 & 7 & 2 & 91 \\
\hline 2013 & 44 & 0 & 56 & 4 & 0 & 96 & 43 & 2 & 55 & 4 & 0 & 96 & 25 & 0 & 75 & 22 & 0 & 77 \\
\hline 2014 & 72 & 1 & 27 & 0 & 0 & 100 & 71 & 0 & 29 & 15 & 0 & 85 & 10 & 1 & 89 & 16 & 0 & 84 \\
\hline \multicolumn{19}{|c|}{ Locust Creek near Linneus, Missouri } \\
\hline 2011 & 47 & 0 & 53 & 6 & 9 & 84 & 68 & 0 & 32 & 1 & 22 & 77 & 21 & 3 & 76 & 19 & 0 & 80 \\
\hline $2011^{\mathrm{a}}$ & 58 & 0 & 42 & 0 & 0 & 100 & 68 & 0 & 32 & 6 & 72 & 22 & 27 & 0 & 73 & 21 & 0 & 79 \\
\hline 2012 & 22 & 2 & 76 & 16 & 0 & 84 & 30 & 2 & 68 & 0 & 46 & 54 & 22 & 0 & 78 & 7 & 8 & 85 \\
\hline 2013 & 39 & 0 & 61 & 1 & 0 & 99 & 40 & 0 & 60 & 20 & 56 & 24 & 16 & 0 & 84 & 15 & 1 & 84 \\
\hline 2014 & 34 & 1 & 65 & 0 & 86 & 14 & 37 & 0 & 62 & 1 & 4 & 96 & 16 & 0 & 84 & 9 & 1 & 90 \\
\hline 2016 & 63 & 0 & 36 & 0 & 0 & 100 & 66 & 0 & 33 & 66 & 0 & 34 & 7 & 1 & 93 & 4 & 1 & 95 \\
\hline 2017 & 39 & 0 & 61 & 0 & 0 & 100 & 48 & 0 & 52 & 3 & 0 & 97 & 5 & 1 & 93 & 2 & 1 & 97 \\
\hline \multicolumn{19}{|c|}{ Hickory Branch near Mendon, Missouri } \\
\hline 2013 & 50 & 1 & 49 & 0 & 0 & 100 & 51 & 0 & 49 & 100 & 0 & 0 & 38 & 3 & 59 & 35 & 3 & 62 \\
\hline 2014 & 9 & 11 & 80 & 0 & 0 & 0 & 7 & 11 & 82 & 0 & 0 & 0 & 4 & 6 & 90 & 3 & 18 & 79 \\
\hline 2016 & 27 & 1 & 72 & 0 & 0 & 100 & 27 & 0 & 73 & 25 & 0 & 75 & 10 & 9 & 81 & 12 & 9 & 79 \\
\hline 2017 & 26 & 11 & 63 & 0 & 0 & 100 & 24 & 1 & 75 & 3 & 0 & 97 & 3 & 13 & 84 & 3 & 4 & 93 \\
\hline
\end{tabular}

aReplicate sample. 
The "SOFTASTN" attribute describes soft algae as indicating either high (metric class 1) or low (metric class 2) total nitrogen; however, most soft algae were not described (NA). The average relative abundance of undescribed soft algae was 92 percent, and average relative abundances of soft algae described as high or low total nitrogen were less than 5 percent (table 7). The large abundance of undescribed soft algae indicates total nitrogen concentrations may not be affecting the soft algae community or that there are many taxa with unknown total nitrogen preferences.

The "DIATASTP" attribute describe diatoms that are indicators of high (metric class 1) or low (metric class 2) total phosphorus (Porter, 2008). Diatoms that are indicators of high total phosphorus were identified in all samples, and relative abundances ranged from 7 to 99 percent, with an average relative abundance of 46 percent (tables 7, 9). Low total phosphorus indicating diatoms were identified in 31 percent of samples, the maximum relative abundance was 11 percent, and the average relative abundance was 1 percent. The sample with the greatest abundance of low total phosphorus indicating diatoms (Hickory Branch in 2014) was the only sample with a greater abundance of low total phosphorus diatoms (11 percent) than high total phosphorus diatoms ( 7 percent). This was also the only sample that had a greater abundance of diatoms indicating low total nitrogen than high total nitrogen (table 9). Diatoms indicating high total phosphorus were identified in all samples and in greater abundances than low total phosphorus diatoms. This indicates that high total phosphorus conditions likely are common and are affecting the periphyton community.

The "SOFTASTP" attribute describes soft algae as indicating either high (metric class 1) or low (metric class 2) total phosphorus; however, most soft algae were not described (NA). The average relative abundance of undescribed soft algae was 66 percent and average relative abundances of soft algae described as high or low total nitrogen indicating were less than 15 and 17 percent, respectively (table 7). High total phosphorus indicating soft algae were present in a slightly greater number of samples (64 percent) than low indicating (49 percent). The large abundance of undescribed taxa indicates total phosphorus concentrations may not be affecting the soft algae community or that there are many taxa with unknown total phosphorus preferences. Attributes specifically for total nitrogen and total phosphorus indicate high total nitrogen and high total phosphorus conditions are likely affecting the diatom community, but many soft algae were undescribed, which indicates soft algae are not as sensitive to total nitrogen and total phosphorus concentrations or that there are a greater number of soft algae taxa with unknown nitrogen and phosphorus concentration preferences.
Regional attributes for the central and western plains describe diatoms indicating high and low total nitrogen (WPTN) and total phosphorus (WPTP). Average relative abundances of undescribed taxa (NA) were greater for both regional attributes than diatoms described as high or low indicating (tables 7, 9). Diatoms indicating high total nitrogen and diatoms indicating high total phosphorus were identified in all samples and at greater average relative abundances than low total nitrogen or low total phosphorus diatoms. Although there were large abundances of undescribed diatoms in the regional attributes, high total nitrogen indicating and high total phosphorus indicating diatoms were present in all samples and at greater abundances than low total nitrogen and phosphorus indicating diatoms. This information is consistent with national attributes and indicates high total nitrogen and high total phosphorus conditions are likely affecting the diatom community structure.

Many attributes were used to describe periphyton community nutrient tolerances and preferences, including attributes for diatoms (TROPHIC, DIATASTN, DIATASTP, WPTN, and WPTP), soft algae (EUTROPHIC SOFT, SOFTASTN and SOFTASTP), and both combined (NF and EUTROPHIC); attributes also included tolerances for nutrients in general, and specifically for total nitrogen and total phosphorus. Diatoms that are associated with high nutrient environments, high total nitrogen, and high total phosphorus were identified in all samples and at greater abundances than those associated with low nutrient environments, low total nitrogen, and low total phosphorus. Soft algae that are tolerant to or require high nutrient concentrations were identified in most samples and often in high abundances. Soft algae attributes for total nitrogen and total phosphorus had greater abundances of undescribed soft algae than those indicating high or low total nitrogen or high or low total phosphorus. These soft algae attributes specifically for total nitrogen and total phosphorus did not provide much information. Although there were large abundances of undescribed diatoms in regional attributes, high total nitrogen indicating and high total phosphorus indicating diatoms were present in all samples and at greater abundances than low total nitrogen and low phosphorus indicating diatoms. These attributes provide substantial evidence that high nutrient conditions, including total nitrogen and total phosphorus are common and persistent enough to affect the overall periphyton community structure. Because periphyton are the base of the food chain and link physical properties to higher trophic classes, the overall ecological health is likely affected by high nutrient conditions in the Lower Grand River. 
Conditions that are rich in organic material usually result in extremely low dissolved-oxygen concentrations known as saprobic conditions. Large abundances of taxa that can tolerate low dissolved-oxygen concentrations often indicate high organic enrichment because streams with excessive organic enrichment have a high biochemical oxygen demand (BOD) and persistent low dissolved-oxygen concentrations. Streams with little organic enrichment have a low BOD and high dissolved-oxygen concentrations, and the algae community generally are dominated by species associated with high dissolved-oxygen concentrations (Porter and others, 2008). Six attributes describe organic enrichment or oxygen saturation (Porter, 2008), including the SAPROBIC attribute that associates diatoms with oxygen saturation and BOD conditions, an oxygen tolerance attribute (OXYTOL), an organic nitrogen tolerance attribute (ORG_N), a nutrient and organic enrichment tolerance attribute (POLL_CLASS), an attribute that classifies tolerance to degraded conditions (POLL_TOL), and an attribute that identifies harmful algal bloom producers (NUISANCE ALGAE; Porter, 2008; tables 7, 10, 11).

The SAPROBIC attribute classifies taxa associated with oxygen saturation and BOD conditions, and metric classes range from oligosaprobous diatoms associated with high dissolved-oxygen concentrations and low BOD (metric class 1 ) to polysaprobous diatoms associated with low dissolved-oxygen concentrations and high BOD (metric class 5; Porter, 2008). The greatest average relative abundance was 31 percent for metric class 2 , which describes fairly high dissolved-oxygen concentrations and a fairly low BOD (table 7), and the maximum abundance of diatoms in metric 2 was 80 percent. Maximum abundances were greater for metric class 4 (98 percent) and metric class 1 (92 percent), but the average relative abundances were 14 and 9 percent, respectively. Metric class 1 describes high dissolved-oxygen concentrations and low BOD, and metric class 4 describes fairly low dissolved-oxygen concentrations and fairly high BOD (Porter, 2008). Identified diatoms were associated with a range of dissolved oxygen and BOD conditions from high dissolved-oxygen concentrations and low BOD to fairly low dissolved-oxygen concentrations and fairly high BOD, and the SAPROBIC metric does not indicate that persistently high or low dissolved oxygen or BOD conditions are affecting the periphyton community.

The OXYTOL attribute classifies diatom oxygen tolerance into 5 metric classes ranging from oxygen always high and nearly 100 percent dissolved-oxygen saturation (metric class 1 ) to oxygen very low and dissolved-oxygen saturation about 10 percent or less (metric class 5; Porter, 2008). The average relative abundances of identified diatoms for OXYTOL metric classes ranged from 3 to 24 percent, and more diatoms were not associated with an OXYTOL metric class (NA; 41 percent; table 7). Metric class 2 had the greatest average relative abundance, but metric class 4 had a greater maximum abundance (table 11). Like the SAPROBIC attribute, the OXYTOL attribute does not indicate that persistently high or low dissolved-oxygen saturation is affecting the periphyton community.

The ORG_N attribute classifies diatoms by organically bound nitrogen $(\mathrm{OBN})$ tolerance or requirements and include taxa that are generally intolerant to OBN (metric class 1), taxa tolerant to OBN (metric class 2), and taxa indicative of elevated concentrations of OBN (metric classes 3 plus 4; Porter, 2008). Diatoms tolerant to OBN (metric class 2) had the greatest average relative abundance ( 30 percent) of described metric classes and were in all but one sample (tables 7, 11). Diatoms indicative of elevated OBN were in all samples and had an average relative abundance of 17 percent. Intolerant diatoms had the lowest average relative abundance (7 percent) but were in 89 percent of samples. Diatoms that are tolerant to OBN and diatoms indicative of elevated OBN were in greater abundance than diatoms intolerant of OBN, but intolerant diatoms were in most samples. This indicates that high concentrations of OBN may occur and are affecting the periphyton community.

The POLL_CLASS attribute classifies diatoms based on tolerance to nutrient and organic enrichment, and metrics include diatoms very tolerant (metric class 1), diatoms somewhat tolerant (metric class 2), and diatoms that are sensitive to nutrient and organic enrichment (metric class 3 ; Porter, 2008). Diatoms in each metric class were identified in all samples, but somewhat tolerant diatoms had the greatest average relative abundance ( 42 percent) and a maximum abundance of 93 percent (tables 7,11). Very tolerant diatoms had an average relative abundance of 14 percent and a maximum abundance of 98 percent. Sensitive diatoms were in all samples but had the lowest average abundance (10 percent) and the lowest maximum abundance (37 percent). Larger abundances of diatoms were identified that are somewhat tolerant and very tolerant to nutrient and organic enrichment than sensitive diatoms, but sensitive diatoms were identified in all samples, which indicates nutrient and organic enrichment may be common enough to affect the periphyton community.

The POLL_TOL attribute classified diatoms based on tolerance to degraded conditions, and metric classes range from very tolerant diatoms (metric class 1 ), indicating high amounts of organic enrichment, to less tolerant diatoms (metric class 5), indicating low amounts of organic enrichment (Porter, 2008). Most diatoms identified were not described in these metric classes (NA), and average relative abundances ranged from 2 to 7 percent for described metric classes. The large abundance of diatoms not described in the POLL_TOL attribute makes it difficult to gain information. 


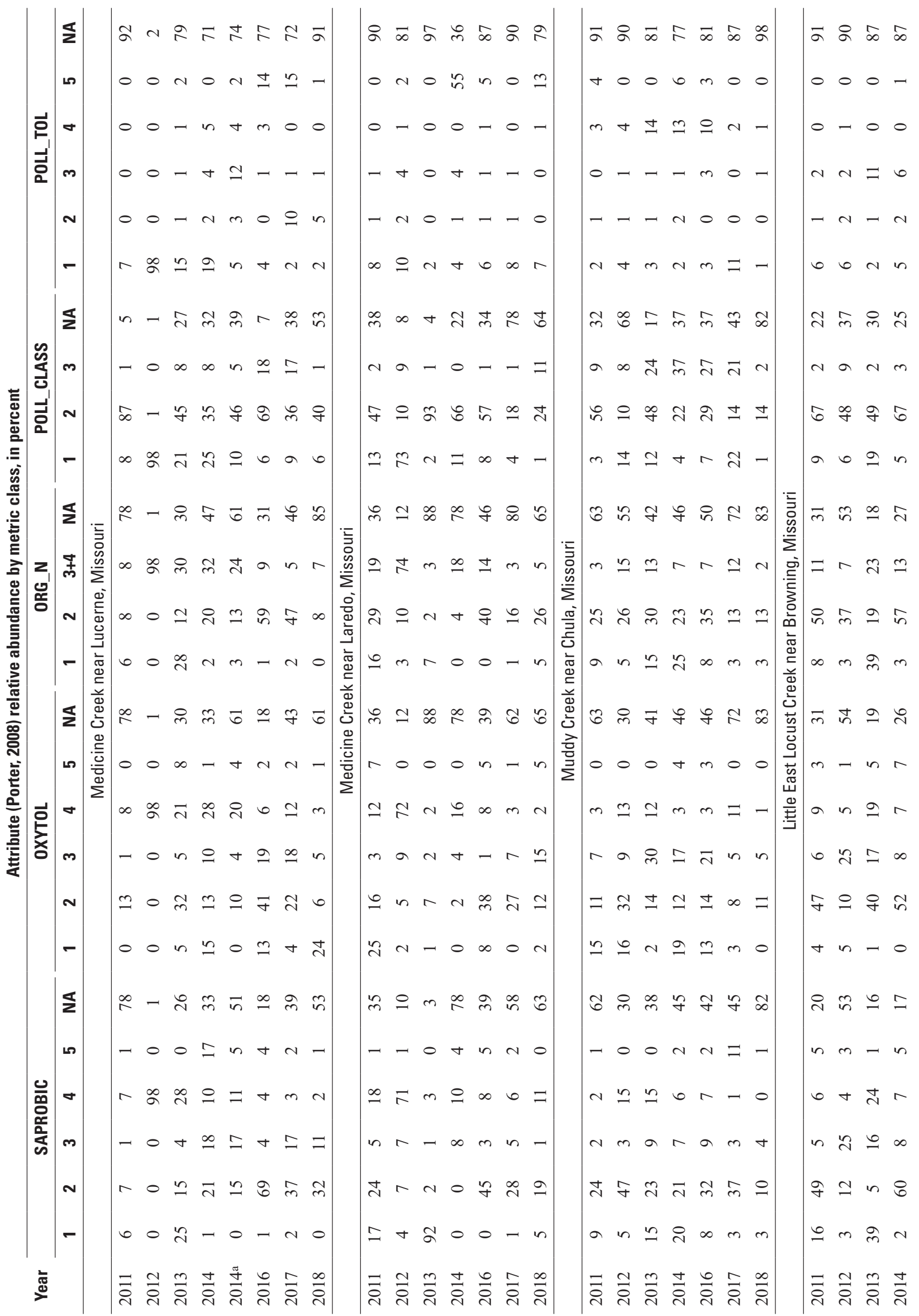




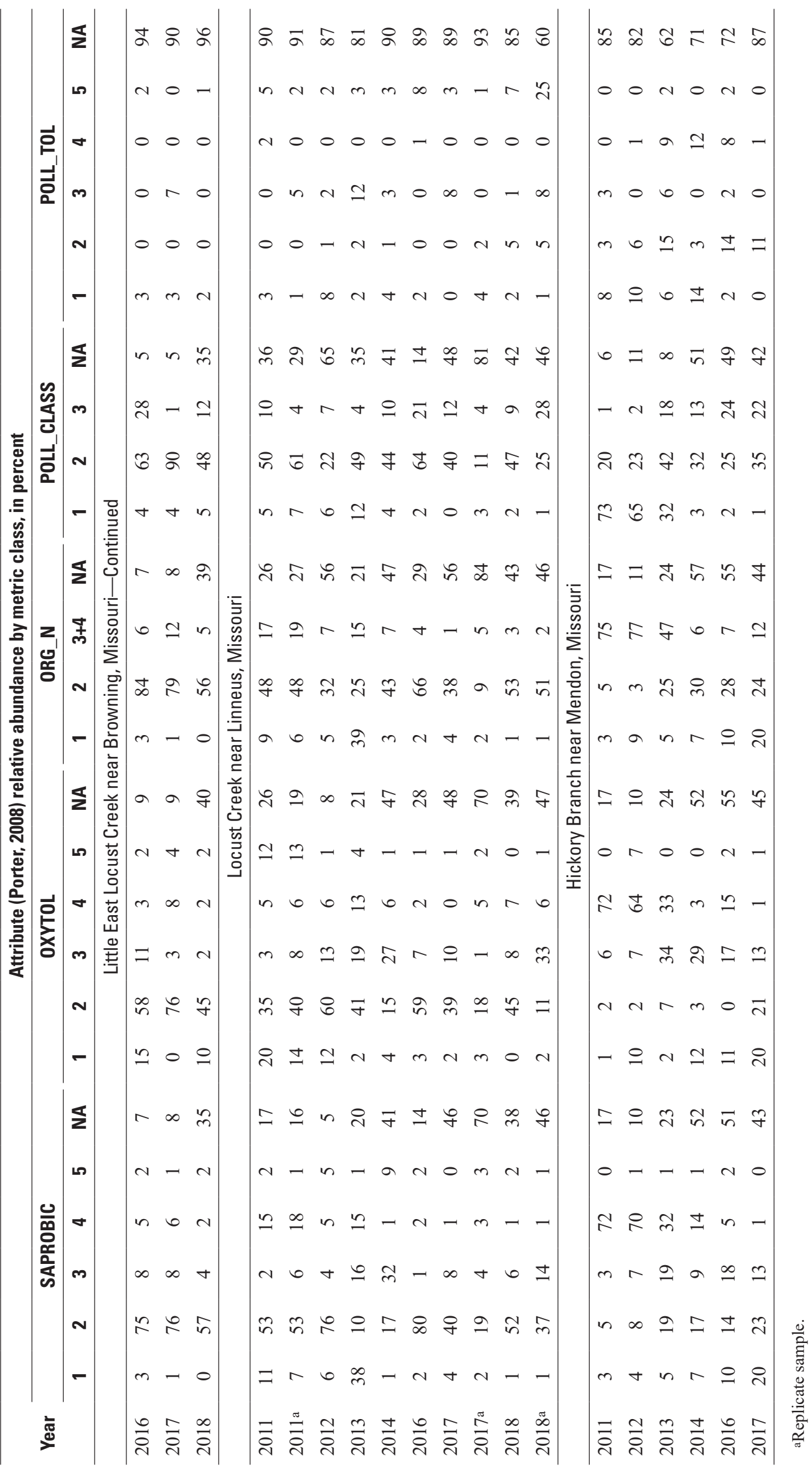


Table 11. Relative abundance of national attributes describing nuisance algae, pH, and salinity (Porter, 2008) by metric class for periphyton samples collected in the Lower Grand River hydrologic unit, Missouri and lowa, 2011 through 2018.

\begin{tabular}{|c|c|c|c|c|c|c|c|c|c|c|c|c|c|c|c|c|c|c|c|c|c|}
\hline \multirow{3}{*}{ Year } & \multicolumn{21}{|c|}{ Attribute (Porter, 2008) relative abundance by metric class, in percent } \\
\hline & \multicolumn{3}{|c|}{ NUISANCE ALGAE } & \multicolumn{7}{|c|}{$\mathbf{p H}$} & \multicolumn{6}{|c|}{ SOFT_pH } & \multicolumn{5}{|c|}{ SALINITY } \\
\hline & 1 & 2 & NA & 1 & 2 & 3 & 4 & 5 & 6 & NA & 1 & 2 & 3 & 4 & 5 & NA & 1 & 2 & 3 & 4 & NA \\
\hline 2011 & 0 & 0 & 100 & 0 & 0 & 2 & 19 & 4 & 0 & 76 & 0 & 2 & 0 & 12 & 82 & 3 & 0 & 22 & 3 & 0 & 76 \\
\hline 2012 & 0 & 0 & 100 & 0 & 0 & 1 & 98 & 0 & 0 & 1 & 0 & 2 & 0 & 12 & 85 & 0 & 0 & 99 & 0 & 0 & 1 \\
\hline 2014 & 0 & 35.9 & 64.2 & 0 & 1 & 19 & 52 & 8 & 0 & 20 & 0 & 0 & 0 & 75 & 1 & 25 & 1 & 45 & 25 & 0 & 29 \\
\hline $2014^{a}$ & 0 & 0 & 100 & 0 & 0 & 7 & 43 & 0 & 3 & 47 & 0 & 3 & 0 & 0 & 10 & 87 & 0 & 42 & 8 & 0 & 50 \\
\hline 2016 & 0 & 14.7 & 85.3 & 0 & 0 & 6 & 73 & 14 & 0 & 7 & 0 & 0 & 0 & 68 & 22 & 10 & 0 & 65 & 28 & 0 & 7 \\
\hline 2017 & 0.03 & 7.24 & 92.7 & 0 & 0 & 3 & 44 & 15 & 0 & 38 & 11 & 0 & 0 & 7 & 50 & 32 & 3 & 37 & 21 & 0 & 38 \\
\hline 2018 & 0 & 0 & 100 & 0 & 0 & 3 & 43 & 0 & 0 & 53 & 0 & 0 & 0 & 0 & 81 & 19 & 4 & 11 & 32 & 0 & 53 \\
\hline 2013 & 0 & 0 & 100 & 0 & 1 & 2 & 10 & 87 & 0 & 1 & 0 & 5 & 1 & 35 & 58 & 1 & 0 & 12 & 2 & 84 & 2 \\
\hline 2014 & 0 & 0 & 100 & 0 & 0 & 6 & 72 & 0 & 0 & 23 & 0 & 0 & 0 & 0 & 3 & 97 & 0 & 20 & 2 & 0 & 77 \\
\hline 2016 & 0 & 0 & 100 & 0 & 0 & 7 & 58 & 0 & 0 & 34 & 0 & 0 & 0 & 0 & 8 & 92 & 0 & 47 & 18 & 0 & 35 \\
\hline 2017 & 0 & 0 & 100 & 0 & 0 & 2 & 40 & 0 & 0 & 58 & 0 & 0 & 0 & 25 & 48 & 27 & 1 & 36 & 5 & 0 & 58 \\
\hline 2018 & 0 & 0 & 100 & 0 & 0 & 1 & 27 & 8 & 1 & 63 & 0 & 0 & 0 & 0 & 66 & 34 & 0 & 30 & 6 & 0 & 63 \\
\hline \multicolumn{22}{|c|}{ Muddy Creek near Chula, Missouri } \\
\hline 2011 & 0.56 & 0 & 99.4 & 0 & 0 & 3 & 38 & 9 & 0 & 50 & 0 & 8 & 2 & 89 & 0 & 1 & 1 & 36 & 6 & 0 & 57 \\
\hline 2012 & 0 & 0 & 100 & 0 & 0 & 11 & 60 & 2 & 0 & 27 & 0 & 6 & 0 & 93 & 0 & 1 & 0 & 68 & 5 & 0 & 27 \\
\hline 2011 & 0.82 & 0 & 99.2 & 0 & 0 & 23 & 63 & 2 & 0 & 12 & 0 & 0 & 0 & 99 & 0 & 1 & 10 & 66 & 7 & 0 & 17 \\
\hline 2012 & 13.1 & 0 & 86.9 & 0 & 0 & 8 & 54 & 2 & 0 & 37 & 0 & 1 & 0 & 20 & 61 & 18 & 1 & 26 & 36 & 1 & 37 \\
\hline 2013 & 0 & 0 & 100 & 0 & 0 & 19 & 52 & 25 & 0 & 4 & 0 & 2 & 0 & 4 & 0 & 94 & 0 & 74 & 12 & 0 & 14 \\
\hline 2014 & 0 & 0 & 100 & 0 & 0 & 9 & 73 & 1 & 0 & 17 & 0 & 0 & 0 & 15 & 0 & 85 & 3 & 75 & 9 & 0 & 14 \\
\hline 2016 & 0 & 0 & 100 & 0 & 0 & 3 & 88 & 2 & 0 & 6 & 0 & 0 & 0 & 68 & 7 & 25 & 0 & 92 & 2 & 0 & 6 \\
\hline 2017 & 0.03 & 0 & 100 & 0 & 0 & 1 & 94 & 0 & 0 & 5 & 0 & 0 & 0 & 55 & 2 & 43 & 0 & 88 & 4 & 2 & 6 \\
\hline 2018 & 33.6 & 0 & 66.4 & 0 & 0 & 2 & 63 & 0 & 0 & 35 & 0 & 0 & 0 & 67 & 15 & 18 & 3 & 59 & 4 & 0 & 35 \\
\hline \multicolumn{22}{|c|}{ Locust Creek near Linneus, Missouri } \\
\hline 2011 & 2.88 & 0 & 97.1 & 0 & 0 & 8 & 77 & 9 & 0 & 5 & 0 & 10 & 1 & 88 & 0 & 1 & 2 & 67 & 16 & 0 & 15 \\
\hline $2011^{a}$ & 0 & 0 & 100 & 0 & 0 & 14 & 81 & 3 & 0 & 3 & 0 & 41 & 3 & 17 & 0 & 38 & 1 & 70 & 15 & 0 & 14 \\
\hline 2012 & 11.1 & 0 & 88.9 & 0 & 0 & 16 & 78 & 3 & 0 & 3 & 0 & 2 & 1 & 76 & 0 & 21 & 2 & 90 & 5 & 0 & 2 \\
\hline 2013 & 0 & 0 & 100 & 0 & 0 & 14 & 50 & 32 & 0 & 4 & 0 & 1 & 0 & 4 & 94 & 0 & 0 & 72 & 13 & 0 & 14 \\
\hline 2014 & 28.7 & 0 & 71.4 & 0 & 0 & 23 & 28 & 12 & 0 & 37 & 0 & 0 & 0 & 86 & 1 & 13 & 0 & 43 & 13 & 6 & 39 \\
\hline 2016 & 0 & 0 & 100 & 0 & 0 & 14 & 67 & 5 & 0 & 14 & 0 & 0 & 0 & 3 & 33 & 65 & 0 & 82 & 4 & 0 & 14 \\
\hline 2017 & 0 & 0 & 100 & 0 & 0 & 1 & 52 & 2 & 0 & 45 & 0 & 0 & 27 & 0 & 0 & 73 & 0 & 52 & 3 & 0 & 45 \\
\hline
\end{tabular}


Table 11. Relative abundance of national attributes describing nuisance algae, $\mathrm{pH}$, and salinity (Porter, 2008) by metric class for periphyton samples collected in the Lower Grand River hydrologic unit, Missouri and lowa, 2011 through 2018._-Continued

\begin{tabular}{|c|c|c|c|c|c|c|c|c|c|c|c|c|c|c|c|c|c|c|c|c|c|}
\hline \multirow{3}{*}{ Year } & \multicolumn{21}{|c|}{ Attribute (Porter, 2008) relative abundance by metric class, in percent } \\
\hline & \multicolumn{3}{|c|}{ NUISANCE ALGAE } & \multicolumn{7}{|c|}{ pH } & \multicolumn{6}{|c|}{ SOFT_pH } & \multicolumn{5}{|c|}{ SALINITY } \\
\hline & 1 & 2 & NA & 1 & 2 & 3 & 4 & 5 & 6 & NA & 1 & 2 & 3 & 4 & 5 & NA & 1 & 2 & 3 & 4 & NA \\
\hline \multicolumn{22}{|c|}{ Locust Creek near Linneus, Missouri-Continued } \\
\hline $2017 \mathrm{a}$ & 0 & 0 & 100 & 0 & 0 & 6 & 25 & 0 & 0 & 69 & 0 & 2 & 0 & 5 & 5 & 87 & 0 & 25 & 6 & 0 & 69 \\
\hline 2018 & 0 & 0 & 100 & 0 & 0 & 2 & 53 & 8 & 0 & 38 & 0 & 0 & 0 & 0 & 2 & 98 & 0 & 55 & 9 & 0 & 36 \\
\hline \multicolumn{22}{|c|}{ Hickory Branch near Mendon, Missouri } \\
\hline 2011 & 0 & 72.1 & 27.9 & 0 & 0 & 65 & 18 & 0 & 0 & 17 & 0 & 0 & 0 & 91 & 8 & 0 & 0 & 82 & 1 & 0 & 17 \\
\hline 2012 & 0 & 0 & 100 & 0 & 0 & 64 & 32 & 0 & 0 & 4 & 0 & 1 & 1 & 8 & 89 & 2 & 0 & 83 & 15 & 0 & 2 \\
\hline 2013 & 0 & 99.4 & 0.63 & 0 & 1 & 32 & 53 & 0 & 1 & 14 & 0 & 0 & 0 & 100 & 0 & 0 & 2 & 72 & 8 & 0 & 18 \\
\hline 2014 & 0 & 0 & 100 & 0 & 0 & 13 & 32 & 3 & 0 & 51 & 0 & 0 & 0 & 0 & 0 & 0 & 0 & 42 & 6 & 0 & 51 \\
\hline
\end{tabular}

aReplicate sample.

Nuisance algae producers are identified in NUISANCE ALGAE attribute as either benthic (bottom dwelling or attached) harmful algal bloom producers (metric class 1) or sestonic (suspended or floating) harmful algal bloom producers (metric class 2); taxa that are not identified as bloom producers and undescribed taxa are included in the NA class (Porter, 2008). Nuisance algae were identified in 13 samples and at all sites except Medicine Creek near Laredo (tables 7, 11). Sestonic harmful algal bloom producers were identified at two sites with a maximum abundance of about 99 percent at Hickory Branch in 2013. At this site, about 72 percent of the sample in 2011 were sestonic bloom producers. Three samples at Medicine Creek near Lucerne had sestonic bloom producers, and relative abundances were about 7,15 , and 36 percent. No other sites had sestonic bloom producers. Nine samples, or 20 percent of samples, had benthic bloom producers, with a maximum of 34 percent at Hickory Branch in 2018 (tables 7, 11). The average relative abundances of taxa described as benthic or sestonic harmful algal bloom producers were low ( 2 and 5 percent, respectively), but bloom producers were identified in all sites, except one, and large abundances of were identified at some sites. Harmful algal blooms are not well understood and can occur and move quickly, and potential for harmful algal blooms during optimal conditions may be high at these sites.

The $\mathrm{pH}$ of aquatic systems can indicate nutrient enrichment. High nutrient environments typically are base rich with high alkalinity and high $\mathrm{pH}$, and low nutrient environments are base poor with low alkalinity and low $\mathrm{pH}$ (Porter and others, 2008). Two $\mathrm{pH}$ attributes ( $\mathrm{pH}$ and SOFT_pH) classify diatoms into 6 metric classes and soft algae into 5 metric classes, respectively, based on optimal $\mathrm{pH}$ ranges (Porter, 2008).
Most diatom taxa were identified as preferring a $\mathrm{pH}$ greater than 7 with an optimum pH around 7 (metric class 4), which had an average relative abundance of 51 percent (tables 7,11). Diatoms in this metric class were identified in all samples. Diatoms that prefer a pH around 7 (metric class 3) were also identified in all samples, and this metric class had an average relative abundance of 13 percent. All other classes, except NA, had average relative abundances less than 10 percent, and no identified diatoms had an optimum $\mathrm{pH}$ less than 5.5 (metric class 1).

Most soft algae were classified in the two metric classes that describe taxa with a $\mathrm{pH}$ optimum greater than 7.5 (classes 4 and 5; tables 7, 11). The average relative abundances were 33 (metric class 4; $\mathrm{pH}$ optimum between 7.6 and 8.0 ) and 27 percent (metric class 5; pH optimum greater than 8 ). Soft algae with optimum $\mathrm{pH}$ ranges 7.5 or less (metric classes 1,2 , and 3 ) were identified in small abundances, averaging 2 percent or less.

Diatoms and soft algae that prefer a $\mathrm{pH}$ less than 7 were identified in low abundances, most identified soft algae were described to prefer a $\mathrm{pH}$ greater than 7.5 , and most diatoms were described to prefer a $\mathrm{pH}$ greater than 7 . The average $\mathrm{pH}$ at sites during periphyton sampling was 8.0 and ranged from 7.2 to 9.1. Periphyton samples are collected during low-flow conditions when nutrients are generally lower than during runoff conditions at these sites (Krempa and Flickinger, 2017), and high $\mathrm{pH}$ conditions could indicate elevated nutrient concentrations because these environments typically are base rich with high alkalinity and high $\mathrm{pH}$ (Porter and others, 2008). Having elevated nutrients during low streamflow, when nutrients are generally at their lowest, may indicate that nutrients are consistently elevated in this watershed. 
Abundances of periphyton with high salinity preferences increase with nutrient and suspended-sediment concentrations (Porter and others, 2008). The SALINITY attribute classifies diatoms into 4 metric classes based on chloride and salinity preferences that range from freshwater (metric class 1) to brackish water (metric class 4) diatoms (Porter, 2008). Fresh-brackish water diatoms (metric class 2) were the most abundant; they were identified in all samples, had an average relative abundance of 54 percent, and had a maximum abundance of 99 percent (tables 7, 11). Brackish-freshwater diatoms (metric class 3 ) were also identified in all samples, but the average relative abundance was 10 percent, and the maximum abundance was 36 percent. Freshwater and brackish water diatoms (metric classes 1 and 4) were identified in low abundances, averaging 1 and 2 percent, respectively. Most diatoms were identified in the intermediate salinity metrics with the greatest abundances of fresh-brackish water diatoms, and freshwater and brackish water diatoms were identified in low abundances. Samples were collected during the summer, so it is unlikely that road salts affected the salinity during periphyton collection. Because periphyton with high salinity preferences increase with nutrient and suspended-sediment concentrations, the low abundance of freshwater diatoms may indicate nutrient enrichment or high suspended-sediment concentrations.

Specific conductance generally increases with nutrient concentration (Porter and others, 2008; Porter, 2008). Three attributes classify optimum specific conductance ranges for diatoms (DIATCOND), soft algae (SOFTCOND), and for both (NAWQA_COND) into two metrics, taxa with a high specific conductance optimum (metric 1; optima greater than 500 microsiemens per centimeter at 25 degrees Celsius $[\mu \mathrm{S} / \mathrm{cm}])$ and taxa with a low specific conductance optimum (metric class 2; optima less than $200 \mu \mathrm{S} / \mathrm{cm}$; Porter, 2008). The average relative abundances of diatoms identified as having a high or low specific conductance optimum were 5 percent or less, and unclassified taxa had an average relative abundance of 91 percent (tables 7, 12). Soft algae taxa with a high specific conductance optimum were more abundant than taxa with a low specific conductance optimum. The average relative abundance with a high specific conductance optimum was 33 percent, and maximum abundance was 100 percent; whereas, the average relative abundance with a low specific conductance optimum was 4 percent, and maximum abundance was 42 percent. When diatoms and soft algae are combined in a single attribute, the results are like the soft algae attribute results with slightly lower average relative and maximum abundances. Taxa with a high specific conductance optimum had an average relative abundance of 23 percent, and the maximum abundance was 99 percent; and taxa with a low specific conductance optimum had an average relative abundance of 3 percent, and the maximum was 25 percent. The breakpoint between high and low specific conductance optimums was $500 \mu \mathrm{S} / \mathrm{cm}$, and more taxa were identified as having a high specific conductance optimum even though the average specific conductance measured during periphyton sampling was $451 \mu \mathrm{S} / \mathrm{cm}$ and ranged from 162 to $613 \mu \mathrm{S} / \mathrm{cm}$ (table 2). Because the periphyton community indicates a higher specific conductance optimum than was measured during sampling, specific conductance may often be greater than measured during periphyton sampling and could indicate nutrient enrichment at these sites because specific conductance often increases with nutrient concentrations.

Periphyton taxa are described by optimum chloride ranges for diatoms (DIAT_CL), for soft algae (SOFT_CL), and for both (NAWQA_CL) as taxa with a high chloride optimum (metric 1; chloride optima greater than $500 \mu \mathrm{S} / \mathrm{cm}$ ) and taxa with a low specific conductance optimum (metric class 2; chloride optima less than $200 \mu \mathrm{S} / \mathrm{cm}$; Porter, 2008). Average relative abundance of diatoms with a low chloride preference (17 percent) was greater than high chloride preference ( 2 percent), and low chloride taxa were identified in all samples (table 7). However, for soft algae and when the diatoms and soft algae are combined into a single attribute, average relative abundances of taxa with high chloride optimums (33 and 22 percent) were greater than those with low chloride optimums (14 and 16 percent). Diatom and soft algae attributes were not consistent, and most taxa were not described as having a high or low chloride optimums, which indicates chloride concentrations likely are not affecting the periphyton community structure.

Greater amounts of benthic algae (bottom dwelling) are expected in small streams with flowing water, and sestonic (suspended) algae are expected to increase with stream size and total phosphorus and suspended-sediment concentrations (Porter and others, 2008). The BEN_SES attribute describes algae microhabitats as benthic (metric class 1) or sestonic (metric class 2; Porter, 2008). Benthic and sestonic taxa were identified in all samples, and average relative abundances were 78 and 15 percent, respectively (table 7). In most samples ( 82 percent), more than 50 percent of the taxa were benthic (table 13). Greater abundances of benthic taxa were identified than sestonic. Although increased abundances of sestonic algae may indicate increased total phosphorus and suspended-sediment concentrations, greater abundances of benthic algae were expected because the sampled streams were small, samples were collected directly from benthic substrates, and suspended algae (sestonic algae) were not targeted but instead collected passively.

Motile algae can move through the water column or across submerged surfaces and have an ecological advantage to taxa living on unstable sediments (Porter and others, 2008). The MOTILITY attribute classifies taxa as motile (metric class 1) or non-motile (metric class 2; Porter, 2008). The relative abundance of non-motile taxa was slightly greater than motile, with average relative abundances of 57 and 40 percent, respectively (table 13). Motile and non-motile taxa were identified in all samples, and maximum abundances were 90 and 100 percent, respectively (tables 7, 13). Differences between motile and non-motile taxa were not large enough to provide any substantial information. 
Table 12. Relative abundance of national attributes describing conductance and chloride concentrations (Porter, 2008) by metric class for periphyton samples collected in the Lower Grand River hydrologic unit, Missouri and lowa, 2011 through 2018.

\begin{tabular}{|c|c|c|c|c|c|c|c|c|c|c|c|c|c|c|c|c|c|c|}
\hline \multirow{3}{*}{ Year } & \multicolumn{18}{|c|}{ Attribute (Porter, 2008) relative abundance by metric class, in percent } \\
\hline & \multicolumn{3}{|c|}{ DIATCOND } & \multicolumn{3}{|c|}{ SOFTCOND } & \multicolumn{3}{|c|}{ NAWOA_COND } & \multicolumn{3}{|c|}{ DIAT_CL } & \multicolumn{3}{|c|}{ SOFT_CL } & \multicolumn{3}{|c|}{ NAWOA_CL } \\
\hline & 1 & 2 & NA & 1 & 2 & NA & 1 & 2 & NA & 1 & 2 & NA & 1 & 2 & NA & 1 & 2 & NA \\
\hline \multicolumn{19}{|c|}{ Medicine Creek near Lucerne, Missouri } \\
\hline 2011 & 2 & 0 & 98 & 82 & 2 & 16 & 72 & 2 & 26 & 0 & 7 & 93 & 82 & 13 & 5 & 72 & 12 & 16 \\
\hline 2012 & 0 & 0 & 100 & 86 & 2 & 12 & 25 & 1 & 75 & 0 & 98 & 2 & 86 & 11 & 3 & 25 & 73 & 3 \\
\hline 2013 & 7 & 1 & 91 & 89 & 1 & 11 & 85 & 1 & 15 & 0 & 25 & 75 & 89 & 9 & 2 & 84 & 10 & 6 \\
\hline 2014 & 3 & 1 & 96 & 75 & 0 & 25 & 42 & 0 & 58 & 0 & 15 & 85 & 67 & 0 & 33 & 36 & 7 & 57 \\
\hline $2014 \mathrm{a}$ & 1 & 10 & 89 & 9 & 3 & 88 & 0 & 8 & 92 & 1 & 28 & 71 & 0 & 0 & 100 & 0 & 20 & 80 \\
\hline 2016 & 11 & 0 & 89 & 68 & 0 & 32 & 23 & 0 & 77 & 0 & 5 & 95 & 68 & 0 & 32 & 15 & 4 & 81 \\
\hline 2017 & 1 & 0 & 99 & 68 & 0 & 32 & 47 & 0 & 53 & 0 & 9 & 91 & 57 & 0 & 43 & 39 & 3 & 58 \\
\hline 2018 & 3 & 1 & 96 & 1 & 0 & 99 & 2 & 0 & 98 & 3 & 9 & 88 & 1 & 0 & 99 & 2 & 2 & 96 \\
\hline \multicolumn{19}{|c|}{ Medicine Creek near Laredo, Missouri } \\
\hline 2011 & 4 & 3 & 93 & 1 & 1 & 98 & 2 & 2 & 97 & 0 & 14 & 86 & 1 & 69 & 30 & 0 & 54 & 45 \\
\hline 2012 & 8 & 0 & 92 & 64 & 0 & 36 & 60 & 0 & 40 & 0 & 14 & 86 & 64 & 32 & 4 & 59 & 30 & 11 \\
\hline 2013 & 85 & 0 & 15 & 58 & 0 & 42 & 75 & 0 & 25 & 84 & 3 & 13 & 62 & 29 & 9 & 76 & 12 & 12 \\
\hline 2014 & 0 & 0 & 100 & 0 & 0 & 100 & 0 & 0 & 100 & 0 & 2 & 98 & 0 & 0 & 100 & 0 & 2 & 98 \\
\hline 2016 & 4 & 1 & 95 & 0 & 0 & 100 & 4 & 1 & 95 & 0 & 3 & 97 & 0 & 0 & 100 & 0 & 3 & 97 \\
\hline 2017 & 1 & 19 & 80 & 57 & 3 & 40 & 12 & 15 & 73 & 1 & 27 & 72 & 57 & 12 & 31 & 15 & 23 & 62 \\
\hline 2018 & 1 & 1 & 98 & 36 & 0 & 64 & 11 & 1 & 88 & 1 & 10 & 89 & 0 & 0 & 100 & 1 & 7 & 92 \\
\hline \multicolumn{19}{|c|}{ Muddy Creek near Chula, Missouri } \\
\hline 2011 & 4 & 8 & 88 & 1 & 8 & 90 & 3 & 8 & 89 & 0 & 12 & 88 & 1 & 88 & 10 & 1 & 41 & 58 \\
\hline 2012 & 5 & 25 & 70 & 0 & 6 & 94 & 1 & 9 & 90 & 0 & 35 & 65 & 0 & 93 & 7 & 0 & 83 & 17 \\
\hline 2013 & 4 & 1 & 95 & 80 & 0 & 20 & 71 & 0 & 28 & 0 & 27 & 73 & 81 & 17 & 2 & 72 & 18 & 10 \\
\hline 2014 & 3 & 2 & 95 & 0 & 0 & 100 & 2 & 1 & 98 & 2 & 22 & 76 & 0 & 0 & 100 & 1 & 11 & 87 \\
\hline 2016 & 3 & 1 & 96 & 0 & 0 & 100 & 3 & 1 & 96 & 0 & 25 & 75 & 2 & 0 & 98 & 0 & 22 & 78 \\
\hline 2017 & 2 & 0 & 98 & 67 & 0 & 33 & 20 & 0 & 80 & 0 & 17 & 83 & 67 & 0 & 33 & 24 & 11 & 65 \\
\hline 2018 & 0 & 0 & 100 & 0 & 0 & 100 & 0 & 0 & 100 & 0 & 3 & 97 & 0 & 0 & 100 & 0 & 1 & 99 \\
\hline \multicolumn{19}{|c|}{ Little East Locust Creek near Browning, Missouri } \\
\hline 2011 & 4 & 2 & 94 & 1 & 0 & 99 & 2 & 0 & 98 & 0 & 10 & 90 & 1 & 22 & 76 & 1 & 20 & 78 \\
\hline 2012 & 14 & 0 & 86 & 61 & 1 & 39 & 55 & 1 & 45 & 0 & 10 & 90 & 61 & 20 & 19 & 53 & 19 & 29 \\
\hline 2013 & 4 & 0 & 96 & 1 & 0 & 99 & 1 & 0 & 98 & 1 & 6 & 93 & 1 & 0 & 99 & 1 & 2 & 98 \\
\hline 2014 & 1 & 0 & 99 & 15 & 0 & 85 & 1 & 0 & 99 & 0 & 8 & 92 & 15 & 0 & 85 & 0 & 8 & 92 \\
\hline 2016 & 0 & 0 & 100 & 52 & 16 & 32 & 13 & 4 & 82 & 0 & 25 & 75 & 52 & 0 & 48 & 14 & 19 & 68 \\
\hline 2017 & 0 & 0 & 100 & 8 & 42 & 50 & 0 & 1 & 99 & 0 & 3 & 97 & 12 & 0 & 88 & 1 & 3 & 97 \\
\hline 2018 & 2 & 0 & 98 & 5 & 0 & 95 & 4 & 0 & 96 & 2 & 14 & 84 & 1 & 1 & 98 & 1 & 4 & 95 \\
\hline \multicolumn{19}{|c|}{ Locust Creek near Linneus, Missouri } \\
\hline 2011 & 1 & 0 & 99 & 16 & 11 & 73 & 6 & 3 & 91 & 0 & 8 & 92 & 16 & 72 & 12 & 5 & 28 & 67 \\
\hline $2011^{\mathrm{a}}$ & 2 & 10 & 88 & 0 & 41 & 59 & 1 & 16 & 82 & 0 & 12 & 88 & 0 & 34 & 66 & 0 & 16 & 84 \\
\hline 2012 & 3 & 50 & 47 & 17 & 2 & 80 & 11 & 25 & 64 & 0 & 65 & 35 & 16 & 56 & 28 & 8 & 60 & 31 \\
\hline 2013 & 5 & 1 & 94 & 95 & 1 & 4 & 84 & 1 & 14 & 1 & 5 & 94 & 95 & 4 & 1 & 84 & 4 & 12 \\
\hline 2014 & 2 & 1 & 97 & 20 & 0 & 80 & 8 & 1 & 91 & 1 & 7 & 92 & 20 & 0 & 80 & 7 & 5 & 88 \\
\hline 2016 & 1 & 0 & 99 & 3 & 0 & 97 & 1 & 0 & 99 & 0 & 2 & 98 & 3 & 0 & 97 & 0 & 2 & 98 \\
\hline 2017 & 2 & 10 & 88 & 0 & 27 & 73 & 2 & 11 & 87 & 0 & 11 & 89 & 0 & 27 & 73 & 0 & 12 & 88 \\
\hline
\end{tabular}


Table 12. Relative abundance of national attributes describing conductance and chloride concentrations (Porter, 2008) by metric class for periphyton samples collected in the Lower Grand River hydrologic unit, Missouri and lowa, 2011 through 2018. —Continued

\begin{tabular}{|c|c|c|c|c|c|c|c|c|c|c|c|c|c|c|c|c|c|c|}
\hline \multirow{3}{*}{ Year } & \multicolumn{18}{|c|}{ Attribute (Porter, 2008) relative abundance by metric class, in percent } \\
\hline & \multicolumn{3}{|c|}{ DIATCOND } & \multicolumn{3}{|c|}{ SOFTCOND } & \multicolumn{3}{|c|}{ NAWOA_COND } & \multicolumn{3}{|c|}{ DIAT_CL } & \multicolumn{3}{|c|}{ SOFT_CL } & \multicolumn{3}{|c|}{ NAWOA_CL } \\
\hline & 1 & 2 & NA & 1 & 2 & NA & 1 & 2 & NA & 1 & 2 & NA & 1 & 2 & NA & 1 & 2 & NA \\
\hline $2017 \mathrm{a}$ & 2 & 14 & 85 & 5 & 2 & 92 & 4 & 5 & 91 & 0 & 17 & 83 & 5 & 5 & 90 & 4 & 8 & 88 \\
\hline 2018 & 2 & 4 & 93 & 2 & 0 & 98 & 2 & 4 & 94 & 0 & 6 & 94 & 2 & 0 & 98 & 0 & 5 & 95 \\
\hline \multicolumn{19}{|c|}{ Hickory Branch near Mendon, Missouri } \\
\hline 2011 & 0 & 5 & 95 & 68 & 0 & 32 & 66 & 0 & 34 & 0 & 14 & 86 & 83 & 1 & 15 & 80 & 2 & 18 \\
\hline 2012 & 9 & 1 & 90 & 89 & 0 & 11 & 83 & 0 & 17 & 0 & 17 & 83 & 89 & 6 & 5 & 82 & 7 & 11 \\
\hline 2013 & 8 & 1 & 91 & 100 & 0 & 0 & 99 & 0 & 1 & 0 & 31 & 69 & 100 & 0 & 0 & 99 & 0 & 0 \\
\hline 2014 & 0 & 0 & 99 & 0 & 0 & 0 & 0 & 0 & 99 & 0 & 33 & 67 & 0 & 0 & 0 & 0 & 33 & 67 \\
\hline
\end{tabular}

aReplicate sample.

Table 13. Relative abundance of national attributes describing microhabitats, suspended sediments, and calcium concentrations (Porter, 2008) by metric class for periphyton samples collected in the Lower Grand River hydrologic unit, Missouri and lowa, 2011 through 2018.

\begin{tabular}{|c|c|c|c|c|c|c|c|c|c|c|c|c|}
\hline \multirow{3}{*}{ Year } & \multicolumn{12}{|c|}{ Attribute (Porter, 2008) relative abundance by metric class, in percent } \\
\hline & \multicolumn{3}{|c|}{ BEN_SES } & \multicolumn{3}{|c|}{ MOTILITY } & \multicolumn{3}{|c|}{ SOFT_TSS } & \multicolumn{3}{|c|}{ DIAT_CA } \\
\hline & 1 & 2 & NA & 1 & 2 & NA & 1 & 2 & NA & 1 & 2 & NA \\
\hline 2011 & 100 & 0 & 0 & 13 & 87 & 0 & 0 & 13 & 87 & 9 & 0 & 91 \\
\hline 2012 & 100 & 0 & 0 & 2 & 98 & 0 & 0 & 12 & 88 & 1 & 0 & 99 \\
\hline 2014 & 84 & 15 & 1 & 37 & 62 & 1 & 1 & 0 & 99 & 16 & 1 & 83 \\
\hline $2014^{a}$ & 84 & 15 & 0 & 44 & 56 & 0 & 9 & 2 & 90 & 14 & 10 & 76 \\
\hline 2016 & 89 & 9 & 1 & 68 & 31 & 1 & 21 & 1 & 78 & 55 & 0 & 45 \\
\hline 2017 & 73 & 26 & 1 & 46 & 53 & 1 & 0 & 11 & 89 & 13 & 0 & 87 \\
\hline 2018 & 19 & 69 & 12 & 15 & 75 & 9 & 0 & 79 & 21 & 6 & 0 & 94 \\
\hline 2013 & 96 & 4 & 0 & 9 & 91 & 0 & 5 & 31 & 64 & 86 & 0 & 14 \\
\hline 2014 & 93 & 6 & 2 & 14 & 84 & 2 & 0 & 0 & 100 & 12 & 0 & 88 \\
\hline 2016 & 85 & 15 & 1 & 78 & 21 & 1 & 0 & 8 & 92 & 39 & 1 & 60 \\
\hline 2017 & 89 & 9 & 1 & 67 & 32 & 1 & 11 & 12 & 77 & 9 & 0 & 91 \\
\hline 2018 & 64 & 28 & 7 & 55 & 38 & 7 & 0 & 30 & 70 & 5 & 0 & 95 \\
\hline \multicolumn{13}{|c|}{ Muddy Creek near Chula, Missouri } \\
\hline 2011 & 99 & 1 & 0 & 56 & 44 & 0 & 0 & 88 & 12 & 23 & 8 & 70 \\
\hline 2012 & 95 & 1 & 4 & 16 & 80 & 4 & 1 & 93 & 7 & 24 & 0 & 76 \\
\hline
\end{tabular}


Table 13. Relative abundance of national attributes describing microhabitats, suspended sediments, and calcium concentrations (Porter, 2008) by metric class for periphyton samples collected in the Lower Grand River hydrologic unit, Missouri and lowa, 2011 through 2018.-Continued

\begin{tabular}{|c|c|c|c|c|c|c|c|c|c|c|c|c|}
\hline \multirow{3}{*}{ Year } & \multicolumn{12}{|c|}{ Attribute (Porter, 2008) relative abundance by metric class, in percent } \\
\hline & \multicolumn{3}{|c|}{ BEN_SES } & \multicolumn{3}{|c|}{ MOTILITY } & \multicolumn{3}{|c|}{ SOFT_TSS } & \multicolumn{3}{|c|}{ DIAT_CA } \\
\hline & 1 & 2 & NA & 1 & 2 & NA & 1 & 2 & NA & 1 & 2 & NA \\
\hline 2014 & 94 & 5 & 1 & 38 & 61 & 1 & 0 & 0 & 100 & 13 & 0 & 87 \\
\hline 2016 & 75 & 12 & 13 & 51 & 36 & 13 & 0 & 0 & 100 & 23 & 0 & 77 \\
\hline 2018 & 33 & 66 & 2 & 82 & 17 & 1 & 96 & 1 & 3 & 9 & 0 & 91 \\
\hline \multicolumn{13}{|c|}{ Little East Locust Creek near Browning, Missouri } \\
\hline 2011 & 16 & 20 & 64 & 15 & 22 & 63 & 0 & 22 & 78 & 59 & 2 & 39 \\
\hline 2012 & 69 & 31 & 0 & 14 & 86 & 0 & 0 & 20 & 80 & 50 & 0 & 50 \\
\hline 2013 & 26 & 6 & 68 & 19 & 81 & 0 & 2 & 0 & 98 & 20 & 0 & 80 \\
\hline 2018 & 21 & 74 & 4 & 34 & 61 & 4 & 23 & 10 & 67 & 45 & 0 & 55 \\
\hline \multicolumn{13}{|c|}{ Locust Creek near Linneus, Missouri } \\
\hline 2011 & 84 & 16 & 0 & 54 & 46 & 0 & 1 & 72 & 28 & 53 & 0 & 47 \\
\hline $2011^{\mathrm{a}}$ & 85 & 15 & 0 & 72 & 28 & 0 & 0 & 34 & 66 & 45 & 1 & 54 \\
\hline 2012 & 48 & 52 & 0 & 41 & 59 & 0 & 0 & 59 & 41 & 21 & 0 & 79 \\
\hline 2013 & 99 & 1 & 0 & 9 & 91 & 0 & 0 & 4 & 96 & 23 & 1 & 76 \\
\hline 2014 & 40 & 60 & 0 & 34 & 66 & 0 & 0 & 1 & 99 & 11 & 1 & 88 \\
\hline 2016 & 87 & 12 & 0 & 84 & 16 & 0 & 3 & 33 & 65 & 59 & 0 & 41 \\
\hline 2012 & 97 & 2 & 1 & 5 & 95 & 0 & 1 & 7 & 92 & 16 & 0 & 84 \\
\hline 2013 & 100 & 0 & 0 & 0 & 100 & 0 & 0 & 0 & 100 & 25 & 0 & 75 \\
\hline 2014 & 96 & 4 & 0 & 13 & 87 & 0 & 0 & 0 & 0 & 12 & 0 & 88 \\
\hline 2016 & 95 & 3 & 2 & 65 & 33 & 2 & 25 & 0 & 75 & 12 & 0 & 88 \\
\hline 2017 & 93 & 3 & 3 & 42 & 55 & 3 & 1 & 0 & 99 & 21 & 0 & 79 \\
\hline
\end{tabular}

aReplicate sample. 
Suspended sediment can bond to phosphorus and harmful contaminants, such as heavy metals, reduces light availability, and can settle on streambeds smothering habitat necessary for periphyton attachment and macroinvertebrate and fish foraging, refugia, breeding, and egg laying. The SOFT_TSS attribute classifies soft algae as having a high suspended-sediment optimum (metric class 1; greater than $70 \mathrm{mg} / \mathrm{L}$ ) or low suspended-sediment optimum (metric class 2; less than $12 \mathrm{mg} / \mathrm{L}$; Porter, 2008). Most of the taxa were not identified as having a high or low optimum, and undescribed taxa (NA) had an average relative abundance of 74 percent (table 7). The average relative abundance of taxa with a low optimum was slightly greater than high, with 18 and 6 percent, respectively. The high suspended-sediment optimum is defined as greater than $70 \mathrm{mg} / \mathrm{L}$, and the average concentration of suspended-sediment samples collected with periphyton was $27 \mathrm{mg} / \mathrm{L}$ and ranged from 3 to $180 \mathrm{mg} / \mathrm{L}$ (table 3). Periphyton samples were collected during the summer at low flow when suspended-sediment concentrations are known to be less than during runoff conditions (Krempa and Flickinger, 2017). Most of the taxa were not identified as having either high or low suspended-sediment optimums, which suggests suspended-sediment concentrations are not substantially affecting the periphyton community composition during these conditions.

Calcium is not known to be limiting to algal growth but has been related to species composition and overall biomass. The DIAT_CA attribute classifies diatoms as having a high calcium optimum (metric class 1; greater than $40 \mathrm{mg} / \mathrm{L}$ ) or low calcium optimum (metric class 2; less than $12 \mathrm{mg} / \mathrm{L}$; Porter, 2008). Most taxa were not identified as having either a high or low optimum, and the average relative abundance of undescribed taxa (NA) was 72 percent (table 7). Taxa with a high calcium optimum were in greater abundance than low, and average relative abundances were 27 and 1 percent, respectively. The large abundance of taxa not identified as having a high or low calcium optimum suggests calcium concentration does not substantially affect the periphyton community at these sites.

Overall, periphyton community attributes indicate that high nutrient conditions are likely common within the Lower Grand River and are affecting the periphyton community structure. Because periphyton are the base of the food chain and link physical properties to higher trophic classes, the overall ecological health is likely affected by high nutrient conditions in the Lower Grand River. High concentrations of OBN may occur and affect the periphyton community structure. Attributes specifically for total nitrogen and total phosphorus indicate high total nitrogen and total phosphorus conditions are likely affecting the diatom community, but many soft algae were undescribed, which indicates soft algae are not as sensitive to total nitrogen and total phosphorus concentrations or soft algae taxa with unknown nitrogen and phosphorus concentration preferences are in abundance. Regional attributes are consistent with national attributes and indicate high total nitrogen and high total phosphorus conditions are likely affecting the periphyton community structure. Also, high nutrient conditions often lead to harmful algal blooms, and bloom producers were identified in all sites, except one; also, large abundances of harmful algal blooms were identified at some sites, which indicates harmful algal blooms during optimal conditions may have high potential at these sites. The periphyton community structure indicates that nutrient concentrations are high at these sites and are persistent enough to degrade the overall ecological health within the Lower Grand River.

\section{Summary}

Water quality can describe the chemical, physical, and biological state of water, which can change frequently, rapidly, and in response to natural factors and human activities.

These changes also effect biological communities, which can reflect the overall health of the aquatic system over time and space. Periphyton are good indicators of water-quality and ecological health. They are the base of the stream system food web, they link physical and chemical parameters to higher trophic levels, and they have short life cycles allowing them to respond rapidly to physical and chemical changes. Periphyton biomass has been related to nutrient availability and is expected to increase with nutrients; however, many factors, other than nutrient availability, affect periphyton growth. Many preferences, optimum ranges, and ability to tolerate physical and chemical hardships are described for water-quality constituents, physical parameters, and chemical concentrations.

Periphyton samples and water-quality samples were collected in the Lower Grand River hydrologic unit in Missouri and Iowa (hereafter referred to as "Lower Grand River") during 2011 through 2018 to describe the periphyton community and overall ecological health. Water-quality samples were analyzed for suspended-sediment and nutrient concentrations including ammonia plus organic nitrogen, dissolved ammonia, dissolved nitrite, dissolved phosphorus, nitrate plus nitrite, organic nitrogen, dissolved orthophosphate, total nitrogen, and total phosphorus. Periphyton samples were collected during the summer from submerged rocks, when available, or sand-sized particles, and were split for a periphyton biomass and a periphyton community sample. Water-quality concentrations were used to describe conditions during periphyton sampling and were compared to periphyton biomass and community structure. Periphyton community attributes were used to describe water-quality conditions, and sample similarities were compared with sample factors including site, year, identifying laboratory, month, and tertial of total nitrogen, total phosphorus, and suspended-sediment concentrations. Sample similarities were compared with sample factors including site, year, identifying laboratory, month, and tertial of total nitrogen, total phosphorus, and suspended-sediment concentrations, and periphyton community attributes were used to describe water-quality conditions. 
Water-quality sample concentrations of analyzed constituents were generally elevated at all sampled sites. Samples were collected in the summer when streamflow conditions are generally low, and nutrient concentrations are known to be lower during low-flow conditions than high-flow and runoff conditions. The greatest sample concentrations were from Muddy Creek in September 2012 for all sampled constituents except dissolved ammonia, when the sample from Hickory Branch in September 2013 had a greater concentration. Hickory Branch and Muddy Creek samples were consistently among the greatest sample concentrations, especially in September 2012 at Muddy Creek and June or October 2013 at Hickory Branch.

Elevated total nitrogen can lead to eutrophication, excessive plant and algae growth, drinking-water taste and odor problems, low dissolved-oxygen concentrations, and harmful algal blooms. Total nitrogen includes ammonia, nitrate, nitrite, and organic nitrogen concentrations. Ammonia concentrations were less than water-quality criteria and were likely not a problem during these conditions. Dissolved nitrate and nitrite concentrations were not high enough to be directly toxic to humans. Nitrate and nitrite contribute to total nitrogen; however, organic nitrogen generally was the greatest source to total nitrogen, which can lead to eutrophication, excessive plant and algae growth, drinking-water taste and odor problems, low dissolved-oxygen concentrations, and harmful algal blooms. Concentrations of total nitrogen were greater than acceptable concentrations described by the U.S. Environmental Protection Agency.

Elevated phosphorus concentrations can also lead to eutrophication and subsequent problems, and total phosphorus includes phosphorus bound to sediment and dissolved phosphates. Field runoff is likely a large source because phosphorus bound to sediment is more likely from field runoff than groundwater, and dissolved phosphate concentrations were less than 50 percent of the total phosphorous concentrations in most samples. Concentrations of dissolved orthophosphorus were low, which was expected during low-flow conditions, and are likely greater during high-flow and runoff conditions. Total phosphorus concentrations were greater than the described low reference condition concentrations in all samples, and more than 50 percent of the sample concentrations were greater than the high reference concentration. Samples were collected during low-flow conditions when nutrients concentrations are lower than during high-flow and runoff conditions; elevated nutrient concentrations during these conditions indicate nutrient concentrations are likely elevated throughout most of the year. Agriculture is the primary land use within the Lower Grand River and is likely a primary source of nutrients and sediments.

Total periphyton biomass is important because excessive amounts of periphyton can lead to low dissolved-oxygen concentrations that kill fish and other aquatic life, can reduce recreational opportunities such as boating, swimming, and fishing, and can increase costs for irrigation and drinking-water treatment. Ash-free dry mass represents the total organic weight of the sample, and chlorophyll is the primary photosynthetic pigment of periphyton. Chlorophyll concentrations that exceed 100 milligrams per square meter have been described as nuisance algal conditions. Nuisance conditions were determined at all sites; however, algal blooms are not well understood, the conditions that cause them are not determined, and they can occur and move quickly, which means they may occur more frequently within the Lower Grand River than were sampled.

Ash-free dry mass and chlorophyll concentrations were used in ordinary least squares regression models to analyze relations between periphyton biomass and water-quality constituents. Relations were determined significant if statistical probability values were less than 0.05 ; relations were considered strong if the coefficient of determination was greater than 0.80 . There were more significant relations determined between water-quality constituents and chlorophyll than AFDM. Significant relations were determined between AFDM and dissolved-oxygen concentration and percent for all samples combined, dissolved-oxygen percent at Muddy Creek, and dissolved ammonia at Locust Creek. Significant relations were determined between chlorophyll and dissolved ammonia for all samples combined, for Medicine Creek near Lucerne, for Muddy Creek, and for Locust Creek; water temperature for all sites combined; dissolved phosphorus at Medicine Creek near Lucerne; and dissolved orthophosphate at Medicine Creek near Laredo. Other significant relations were determined between chlorophyll and water-quality constituents at Muddy Creek; however, these relations were highly affected by a single data point. Although significant relations were determined, no relations were strong, which indicates that these factors alone are not good predictors of periphyton biomass at these sites or more data are necessary to understand these relations. Factors affecting periphyton biomass may be complex, including more than one limiting factor, both physical and chemical factors, and are still not well understood at these sites. 
Degraded communities are more susceptible to ecological changes than more diverse communities; often they are dominated by a small number of taxa that are tolerant to the degraded conditions, and taxa richness and evenness are reduced. In total, 441 periphyton taxa were identified in 45 samples. The most common algal group was diatoms, followed by green algae. Sample taxa richness ranged from 31 to 78 taxa, with an average of 51 taxa. The six most frequently occurring taxa were in more than 30 samples, are all diatoms associated with eutrophic or hypereutrophic conditions, and are indicators of high total nitrogen and high total phosphorus conditions, except for one that has a wide range of tolerance to nutrient conditions and is only an indicator of high total nitrogen but not total phosphorus. The relative abundances of the most dominant taxa and the sums of the top five dominant taxa were greater in samples collected during 2010 through 2013 than in samples collected during 2014 through 2018, which may indicate a shift to a more diverse community with greater taxa richness and evenness, and improving ecological health. However, it is important to note that the observed changes occurred with the change in identifying laboratories. Inter-laboratory variability can occur because of many factors. Although efforts were made to standardize laboratory procedures and resolve taxonomic name differences, there is still potential for inter-laboratory variability that could skew results. The relative abundances of dominant taxa provide evidence supporting a more diverse and even periphyton community structure; however, inter-laboratory variability may have impacted and skewed this result.

Sample similarities were determined using a two-dimensional MDS plot with taxa biovolumes (micrometer per square centimeter) from community samples. Samples with similar taxa biovolumes plot near each other and more dissimilar samples are farther apart. The MDS plot was visually compared to site information and water-quality sample concentrations by changing the symbology of the plot to display factors that may affect sample similarities including site, year, month, and tertials of total nitrogen, total phosphorus, suspended sediment, chlorophyll, and AFDM concentrations. There was much overlap among years 2011 through 2013 and 2014 through 2017. Samples from 2018 plotted farther from other samples but were more like 2014 through 2017 samples than 2011 through 2013 samples. There is a difference between community taxa biodiversity data collected during 2011 through 2013 and data collected during 2014 through 2018. It is important to note that the observed changes occurred with the change in identifying laboratories, and inter-laboratory variability can occur because of many factors. The MDS plot and relative abundances of dominant taxa provide evidence supporting a change in the periphyton community structure; however, because this change occurred with the change in identifying laboratories, inter-laboratory variability cannot be overlooked as a source of the variability in data.

Periphyton community attributes include tolerances and optimum ranges for a variety of water-quality conditions, and the characteristics of the community can describe the water-quality condition and ecological health. Regional and national community attributes were calculated from taxa metrics using relative biovolumes of taxa identified in community samples. Some identified taxa were not described previously, and some described taxa were not described for all attributes; therefore, relative abundances for community attributes may not equal 100 percent.

In streams with low dissolved nitrogen, large populations of nitrogen fixing algae can form because they can use atmospheric nitrogen and do not rely only on dissolved nitrogen. Non nitrogen fixing algae were more abundant than nitrogen fixing algae, and nitrogen fixing algae abundances were consistently low. This indicates dissolved nitrogen concentrations are likely not low enough to affect periphyton community structure.

High nutrient levels and subsequent water-quality problems, including excessive plant and algae growth, low light availability, and low dissolved-oxygen concentration, can affect periphyton communities and their abilities to tolerate or thrive in different nutrient concentrations are known for many taxa. Eutrophic diatoms are associated with high nutrient environments, were in every sample, and were at the greatest average relative abundance. Taxa associated with low nutrient environments had average relative abundances less than 1 percent. Soft algae that are tolerant to or require high nutrient concentrations were identified in most samples and often in high abundances indicating high nutrient conditions are likely affecting the soft algae community structure. Eutrophic algae, including diatoms and soft algae, were identified in every sample. This indicates high nutrient conditions likely are common and are affecting the periphyton community structure; and because periphyton are the base of the food chain and linked to higher trophic classes, the overall ecological health is likely affected by high nutrient conditions in the Lower Grand River. 
Algal attributes specifically for total nitrogen and total phosphorus were described for diatoms and soft algae. Diatoms indicating high total nitrogen and total phosphorus were identified in all samples and in greater abundances than low total phosphorus diatoms. There was a large abundance of soft algae that were not described as indicating high or low total nitrogen or total phosphorus. This large abundance indicates total nitrogen and total phosphorus concentrations may not be affecting the soft algae community or many taxa with unknown nitrogen preferences are present. There were also large abundances of undescribed diatoms in regional attributes but high total nitrogen and high total phosphorus, indicating diatoms were found in all samples and at greater abundances than low total nitrogen and phosphorus indicating diatoms. Diatom attributes indicate high total nitrogen and high total phosphorus are likely affecting the diatom community structure, and soft algae are either not as sensitive to total nitrogen and total phosphorus concentrations or a greater number of soft algae taxa with unknown nitrogen and phosphorus concentration preferences is present.

Conditions that are rich in organic material usually result in extremely low oxygen concentrations known as saprobic conditions. Large abundances of taxa that can tolerate low dissolved oxygen concentrations often indicate high organic enrichment because streams with excessive organic enrichment have a high biochemical oxygen demand (BOD) and persistent low dissolved oxygen concentrations.

Streams with little organic enrichment have a low BOD, high dissolved oxygen concentrations, and the algae community generally are dominated by species associated with high dissolved oxygen concentrations. Identified diatoms were associated with a range of oxygen and BOD conditions from high dissolved oxygen conditions and a low BOD to fairly low oxygen conditions and fairly high BOD, and the periphyton community does not indicate persistently high or low dissolved oxygen or biochemical oxygen demand conditions.

Diatoms were described by their organically bound nitrogen $(\mathrm{OBN})$ tolerance or requirements and include taxa that are generally intolerant to OBN, taxa tolerant to OBN, and taxa indicative of elevated concentrations of OBN. There were greater abundances of diatoms that are tolerant to and indicative of elevated OBN than diatoms intolerant of OBN, but intolerant diatoms were present in most samples. High concentrations of OBN may occur and affect the periphyton community. Similarly, diatoms were described based on tolerance to nutrient and organic enrichment. Larger abundances of diatoms were identified that are somewhat tolerant and very tolerant to nutrient and organic enrichment than sensitive diatoms, but sensitive diatoms were identified in all samples, which indicates nutrient and organic enrichment may be common enough to affect the periphyton community.

Nuisance algae producers are identified as either benthic (bottom dwelling or attached) harmful algal bloom producers or sestonic (suspended or floating) harmful algal bloom producers. The average relative abundances of taxa described as benthic or sestonic harmful algal bloom producers were low, but bloom producers were identified at all sites, except Medicine Creek near Laredo, and large abundances were identified at some sites. Harmful algal blooms are not well understood and can occur and move quickly; therefore, potential for algal blooms during optimal conditions may be high at these sites.

The $\mathrm{pH}$ of aquatic systems can indicate nutrient enrichment. High nutrient environments typically are base rich with high alkalinity and high $\mathrm{pH}$, and low nutrient environments are base poor with low alkalinity and low $\mathrm{pH}$. Diatoms and soft algae that prefer a $\mathrm{pH}$ less than 7 were identified in low abundances, most identified soft algae were described to prefer a $\mathrm{pH}$ greater than 7.5 , and most diatoms were described to prefer a $\mathrm{pH}$ greater than 7 . The average $\mathrm{pH}$ at sites during periphyton sampling was 8.0 and ranged from 7.2 to 9.1. Periphyton samples were collected during low streamflow conditions when nutrients are generally lower than during runoff conditions at these sites, and high $\mathrm{pH}$ conditions could indicate elevated nutrient concentrations because these environments typically are base rich with high alkalinity and high $\mathrm{pH}$. Having elevated nutrients during low streamflow, when nutrients are generally at their lowest, may indicate that nutrients are consistently elevated in this watershed.

Periphyton with high salinity preferences increase with nutrient and suspended sediment concentrations. Most diatoms were identified in the intermediate salinity metrics with the greatest abundances of fresh-brackish water diatoms. Freshwater and brackish water diatoms were identified in low abundances. Samples were collected during the summer, so it is unlikely that road salts affected the salinity during periphyton collection. Because periphyton with high salinity preferences increase with nutrient and suspended-sediment concentrations, the low abundance of freshwater diatoms may indicate nutrient enrichment.

Specific conductance generally increases with nutrient concentration. The breakpoint between high and low specific conductance optimums was 500 microsiemens per centimeter at 25 degrees Celsius $(\mu \mathrm{S} / \mathrm{cm})$, and there was a greater abundance of taxa identified as having a high specific conductance optimum even though the average specific conductance measured during periphyton sampling was $451 \mu \mathrm{S} / \mathrm{cm}$ and ranged from 162 to $613 \mu \mathrm{S} / \mathrm{cm}$. Because the periphyton community indicates a higher specific conductance optimum than was measured during sampling, specific conductance may often be greater than was measured, which could indicate nutrient enrichment at these sites because specific conductance often increases with nutrient concentrations. 
Overall, the nutrient concentrations in the Lower Grand River are elevated, and the periphyton community indicates that nutrient concentrations are high at these sites and are persistent enough to degrade the overall ecological health. Also, there may be high potential for harmful algal blooms that can be toxic to humans, pets, and livestock during optimal conditions. Because periphyton are the base of the food chain and link physical properties to higher trophic classes, the overall ecological health is likely affected by high nutrient conditions in the Lower Grand River. The primary land use within the Lower Grand River is agriculture, which is likely a main source of nutrients within this area. Conservation practices intended to reduce nutrient loss from agriculture fields have increased through the Mississippi River Basin Healthy Watersheds Initiative and will potentially increase the ecological and physical health of these waterways.

\section{References Cited}

Barbour, M.T., Gerritsen, J., Snyder, B.D., and Stribling, J.B., 1999, Rapid bioassessment protocols for use in streams and wadeable rivers - Periphyton, benthic macroinvertebrates, and fish (2d ed.): U.S. Environmental Protection Agency Report, EPA 841-B-99-002, 18 p.

Borchardt, M.A., 1996, Nutrients, in Stevenson, R.J., Bothwell, M.L., and Lowe, R.L., eds., Algal ecologyFreshwater benthic ecosystems: San Diego, Calif., Academic Press, p. 183-227.

Childress, C.J.O., Forman, W.T., Connor, B.F., and Maloney, T.J., 1999, New reporting procedures based on long-term method detection levels and some considerations for interpretations of water-quality data provided by the U.S. Geological Survey National Water Quality Laboratory: U.S. Geological Survey Open-File Report 99-193, 19 p., accessed September 22, 2020, at https://pubs.er.usgs.gov/publication/ofr99193.

Clarke, K.R., Gorley, R.N., Somerfield, P.J., and Warwich, R.M., 2014, Changes in marine communitiesAn approach to statistical analysis and interpretation (3d ed.): PRIMER-E Ltd., [Also available at http://updates.primer-e.com/primer7/manuals/Methods manual_v7.pdf.]

Dodds, W.K., Smith, V.H., and Lohman, K., 2002, Nitrogen and phosphorus relationships to benthic algal biomass in temperate streams: Canadian Journal of Fisheries and Aquatic Sciences, v. 59, no. 5, p. 865-874, accessed May 6, 2019, at https://doi.org/10.1139/f02-063.
Fishman, M.J., ed., 1993, Method of analysis by the U.S. Geological Survey National Water Quality Laboratory-Determination of inorganic and organic constituents in water and fluvial sediments, U.S. Geological Survey Open-File Report 93-125, 217 p. [Also available at https://doi.org/10.3133/ofr93125.]

Fishman, M.J., Raese, J.W., Gerlitz, C.N., and Husband, R.A., 1994, U.S. Geological Survey approved inorganic and organic methods for the analysis of water and fluvial sediment, 1954-94: U.S. Geological Survey Open-File Report 94-351, 55 p., accessed April 10, 2019, at https://doi.org/10.3133/ofr94351.

Guiry, M.D., and Guiry, G.M., 2020, AlgaeBaseWorld-wide electronic publication: Galway, National University of Ireland, accessed May 6, 2019, at https://www.algaebase.org.

Hambrook-Berkman, J.A., and Canova, M.G., 2007, Algal biomass indicators: U.S. Geological Survey Techniques of Water-Resources Investigations, book 9, chap. A7, sec. 7.4, accessed February 6, 2019, at https://pubs.water.usgs.gov/twri9A7.

Homer, C.G., Dewitz, J.A., Yang, L., Jin, S., Danielson, P., Xian, G., Coulston, J., Herold, N.D., Wickham, J.D., and Megown, K., 2015, Completion of the 2011 National Land Cover Database for the conterminous United States-Representing a decade of land cover change information: Photogrammetric Engineering and Remote Sensing, v. 81, no. 5, p. 345-354.

Horner, R.R., Welch, E.B., and Veenstra, R.B., 1983, Development of nuisance periphytic algae in laboratory streams in relation to enrichment and velocity, in Wetzel, R.G., ed., Periphyton of freshwater ecosystems: The Hague, The Netherlands, Dr. W. Junk Publishers, p. 121-134, accessed March 18, 2020, at https://doi.org/10.1007/978-94-009-7293-3_18.

Howarth, R.W., 2008, Coastal nitrogen pollution-A review of sources and trends globally and regionally: Harmful Algae, v. 8, p. 14-20, accessed April 6, 2019, at https://pubag.nal.usda.gov/catalog/666247.

Jensen, F.B., 2003, Nitrite disrupts multiple physiological functions in aquatic animals: Comparative Biochemistry and Physiology Part A: Molecular \& Integrative Physiology, v. 135, no. 1, p. 9-24, accessed April 10, 2020, at https://doi.org/10.1016/S1095-6433(02)00323-9.

Kann, J., Asarian, J.E., and St. Amand, A., 2015, Initial Analysis of 1990-2013 Phytoplankton and Zooplankton Data for Upper Klamath Lake (Phase I): Prepared by Aquatic Ecosystem Sciences LLC. for the Klamath Tribes Natural Resources Department, 100 p. plus appendices. 
Krempa, H.M., and Flickinger, A.K., 2017, Temporal changes in nitrogen and phosphorus concentrations with comparisons to conservation practices and agricultural activities in the Lower Grand River, Missouri and Iowa, and selected watersheds, 1969-2015: U.S. Geological Survey Scientific Investigations Report 2017-5067, 28 p., accessed January 1, 2018, at https://doi.org/10.3133/sir20175067.

Krempa, H.M., 2020, Periphyton community data within the Lower Grand River hydrologic unit code 10280103, Missouri and Iowa, 2011-2018: U.S. Geological Survey data release, https://doi.org/10.5066/P9BYF1EN.

Kroupova, H., Machova, J., and Svobodova, Z., 2005, Nitrite influence on fish-A review: Veterinarni Medicina, v. 50, no. 11, p. 461-471, accessed March 3, 2020, at https://doi.org/10.17221/5650-VETMED.

Land, L.F., Moring, J.B., Van Metre, P.C., Reutter, D.C., Mahler, B.J., Shipp, A.A., and Ulery, R.L., 1998, Water quality in the Trinity River Basin, Texas, 1992-95: U.S. Geological Survey Circular 1171, accessed March 10, 2020 at https://pubs.usgs.gov/circ/circ1171/.

Lohman, K., Jones, J.R., and Perkins, B.D., 1992, Effects of nutrient enrichment and flood frequency on periphyton biomass in northern Ozark streams: Canadian Journal of Fisheries and Aquatic Sciences, v. 49, no. 6, p. 1198-1205, accessed April 6, 2019, at https://doi.org/10.1139/f92-135.

MacCoy, D.E., 2004, Water-quality and biological conditions in the Lower Boise River, Ada and Canyon Counties, Idaho, 1994-2002: U.S. Geological Survey Scientific Investigations Report 2004-5128, 80 p., accessed February 11, 2020, at https://doi.org/10.3133/sir20045128.

Moulton, S.R., II, Kennen, J.G., Goldstein, R.M., and Hambrook, J.A., 2002, Revised protocols for sampling algal, invertebrate, and fish communities as part of the National Water-Quality Assessment Program: U.S. Geological Survey Open File Report 02-150, 75 p., accessed January 2, 2019, at https://doi.org/10.3133/ofr2002150.

National Research Council, 1995, Nitrate and nitrite in drinking water: Washington, D.C., National Academies Press, Executive Summary, accessed March 2, 2020, at https://www.ncbi.nlm.nih.gov/books/NBK231053/.

Natural Resources Conservation Service [NRCS], variously dated, Mississippi River Basin Healthy Watersheds Initiative: U.S. Department of Agriculture, Natural Resources Conservation Service web page, accessed March 5, 2018, at https://www.nrcs.usda.gov/wps/portal/ $\mathrm{nrcs} /$ detailfull/national/home/?cid=stelprdb1048200.
Patton, C.J., and Kryskalla, J.R., 2003, Methods of analysis by the U.S. Geological Survey National Water Quality Laboratory-Evaluation of alkaline persulfate digestion as an alternative to Kjeldahl digestion for determination of total and dissolved nitrogen and phosphorus in water: U.S. Geological Survey Water-Resources Investigations Report 03-4174, 33 p., accessed January 2, 2018, at https://nwql.usgs.gov/WRIR-03-4174.shtml.

Patton, C.J., and Kryskalla, J.R., 2011, Colorimetric determination of nitrate plus nitrite in water by enzymatic reduction, automated discrete analyzer methods: U.S. Geological Survey Techniques and Methods, book 5, chap. B8, 34 p., accessed January 2, 2018, at https://doi.org/10.3133/tm5B8.

Patton, C.J., and Truitt, E.P., 1992, Methods of analysis by the U.S. Geological Survey National Water Quality Laboratory-Determination of total phosphorus by a Kjeldahl digestion method and an automated colorimetric finish that includes dialysis: U.S. Geological Survey Open-File Report 92-146, 39 p., accessed January 2, 2018, at https://doi.org/10.3133/ofr92146.

Patton, C.J., and Truitt, E.P., 2000, Methods of analysis by the U.S. Geological Survey National Water Quality Laboratory-Determination of ammonium plus organic nitrogen by a Kjeldahl digestion method and an automated photometric finish that includes digest cleanup by gas diffusion: U.S. Geological Survey Open-File Report 2000-170, 31 p., accessed January 2, 2018, at https://doi.org/10.3133/ofr00170.

Petersen, J.C., and Femmer, S.R., 2002, Periphyton communities in streams of the Ozark Plateus and their relations to selected environmental factors: U.S. Geological Survey Water-Resources Investigations Report 2002-4210, 77 p., accessed March 15, 2017. at https://pubs.er.usgs.gov/publication/wri024210.

Porter, S.D., 2008, Algal attributes-An autecological classification of algal taxa collected by the National Water-Quality Assessment Program: U.S. Geological Survey Data Series, v. 329, accessed March 15, 2017, at https://doi.org/10.3133/ds329.

Porter, S.D., Mueller, D.K., Spahr, N.E., Munn, M.D., and Dubrovsky, N.M., 2008, Efficacy of algal metrics for assessing nutrient and organic enrichment in flowing waters: Freshwater Biology, v. 53, no. 5, p. 1036-1054, accessed March 15, 2017, at https://onlinelibrary.wiley.com/doi/full/ 10.1111/j.1365-2427.2007.01951.x.

Rabalais, N.N., Turner, R.E., and Scavia, D., 2002, Beyond science into policy - Gulf of Mexico hypoxia and the Mississippi River: Bioscience, v. 52, p. 129-142. 
Rasmussen, T.J., Poulton, B.C., and Graham, J.L., 2009, Quality of streams in Johnson County, Kansas, and relations to environmental variables, 2003-07: U.S. Geological Survey Scientific Investigations Report 2009-5235, 84 p., with appendixes, accessed March 17, 2017, at https://pubs.usgs.gov/sir/2009/5235/.

Schilling, K.E., Kim, S., and Jones, C.S., 2017, Use of water quality surrogates to estimate total phosphorus concentrations in Iowa rivers: Journal of Hydrology: Regional Studies, v. 12, p. 111-121, accessed February 5, 2020, at https://www.sciencedirect.com/science/article/pii/ S2214581816300611.

Turnipseed, D.P., and Sauer, V.B., 2010, Discharge measurements at gaging stations: U.S. Geological Survey Techniques and Methods, book 3, chap. A8, 87 p., accessed January 2, 2017, at https://doi.org/10.3133/tm3A8.

U.S. Environmental Protection Agency [EPA], variously dated, National water quality inventory report to Congress: U.S. Environmental Protection Agency web page, accessed March 15, 2017, at https://www.epa.gov/waterdata/nationalwater-quality-inventory-report-congress.

U.S. Environmental Protection Agency [EPA], 1993, Method 365.1, revision 2.0-Determination of phosphorus by semi-automated colorimetry: Cincinnati, Ohio, U.S. Environmental Protection Agency, 17 p., accessed March 15, 2017, at https://www.epa.gov/sites/production/ files/2015-08/documents/method_365-1_1993.pdf.

U.S. Environmental Protection Agency [EPA], 2006, East Fork Medicine Creek Sullivan and Putnam Counties, MissouriTotal maximum daily load: U.S. Environmental Protection Agency, Region 7, 14 p., plus appendixes, accessed March 15, 2017, at https://ofmpub.epa.gov/waters10/ attains_impaired_waters.show_tmdl_document?p_tmdl_ doc_blobs_id $=74791$.

U.S. Environmental Protection Agency [EPA], 2013a, Final aquatic life ambient water quality criteria for ammoniaFreshwater 2013: Federal Register, v. 79, no. 163, accessed March 15, 2017, at https://www.govinfo.gov/content/pkg/ FR-2013-08-22/pdf/2013-20307.pdf.

U.S. Environmental Protection Agency [EPA], 2013b, Total nitrogen: U.S. Environmental Protection Agency, accessed March 15, 2017, at https://www.epa.gov/sites/production/ files/2015-09/documents/totalnitrogen.pdf.

U.S. Environmental Protection Agency [EPA], 2017, National water quality inventory-Report to Congress: U.S. Environmental Protection Agency, EPA 841-R-16-011, accessed March 15, 2017, at https://www.epa.gov/waterdata/2017-national-waterquality-inventory-report-congress.
U.S. Environmental Protection Agency [EPA], 2019, Nitrogen and phosphorus in streams in agricultural watersheds: U.S. Environmental Protection Agency, accessed March 15, 2017, at https://cfpub.epa.gov/roe/indicator.cfm?i=31.

U.S. Environmental Protection Agency [EPA], 2020, National Primary Drinking Water Regulations: U.S. Environmental Protection Agency, accessed March 15, 2017, at https://www.epa.gov/ground-water-and-drinking-water/ national-primary-drinking-water-regulations.

U.S. Geological Survey [USGS], 2008, Field measurements (edited by Wilde, F.D.): U.S. Geological Survey Techniques of Water-Resources Investigations, book 9, chap A6, accessed January 2, 2016, at https://doi.org/10.3133/twri09A6.

U.S. Geological Survey [USGS], 2020, USGS water data for the Nation: U.S. Geological Survey National Water Information System database, accessed January 2, 2020, at https://doi.org/10.5066/F7P55KJN.

U.S. Geological Survey [USGS], variously dated, National field manual for the collection of water-quality data: U.S. Geological Survey Techniques of Water-Resources Investigations, book 9, chaps. A1-A10, accessed March 15, 2017, at https://pubs.water.usgs.gov/twri9A.

Ward, M.H., Jones, R.R., Brender, J.D., de Kok, T.M., Weyer, P.J., Nolan, B.T., Villanueva, C.M., and van Breda, S.G., 2018, Drinking water nitrate and human health-An updated review: International Journal of Environmental Research and Public Health, v. 15 , no. 7, p. 1557, accessed March 17, 2020, at https://doi.org/10.3390/ijerph15071557.

Wehr, J.D., Sheath, R.G., and Kociolek, J.P., 2015, Freshwater algae of North America (2d ed.): Academic Press, 1050 p.

Welch, E.B., Jacoby, J.M., Horner, R.R., and Seeley, M.R., 1988, Nuisance biomass levels of periphytic algae in streams: Hydrobiologia, v. 157, no. 2, p. 161-168, accessed November 11, 2019, at https://doi.org/10.1007/BF00006968.

Wilkison, D.H., and Armstrong, D.J., 2015, Water-quality assessment of the Lower Grand River Basin, Missouri and Iowa, USA, in support of integrated conservation practices: River Research and Applications, v. 32, no. 4, p. 583-596, accessed November 20, 2019, at https://doi.org/10.1002/rra.2887. 

For more information about this publication, contact: Director, USGS Central Midwest Water Science Center 1400 Independence Road

Rolla, M0 65401

573-308-3667

For additional information, visit: https://www.usgs.gov/centers/cm-water Publishing support provided by the Rolla and Sacramento Publishing Service Center 


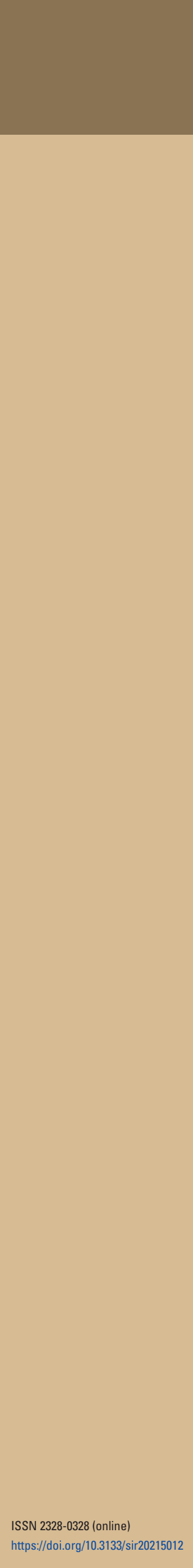

